\title{
Ground Water in the Southeastern Uinta Basin, Utah and Colorado
}

United States Geological Survey Water-Supply Paper 2248

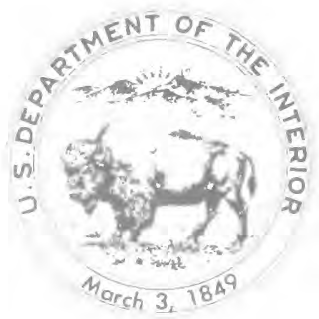




\section{Ground Water in the Southeastern Uinta Basin, Utah and Colorado}

By Walter F. Holmes and Briant A. Kimball 


\section{DEPARTMENT OF THE INTERIOR DONALD PAUL HODEL, Secretary \\ U.S. GEOLOGICAL SURVEY Dallas L. Peck, Director}

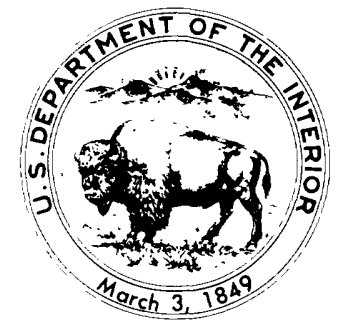

For sale by the

Books and Open-File Reports Section

U.S. Geological Survey

Federal Center

Box 25425

Denver, CO 80225

Library of Congress Cataloging in Publication Data

Holmes, Waiter $F$.

Ground water in the southeastern Uinta Basin, Utah and Colorado

(Water-supply paper ; 2248)

Bibliography: p.

Supt. of Docs. No.: | 19.13:2248

1. Water, Underground-Uinta Basin (Utah and Colo.). I. Kimball,

Briant A. II. Title. III. Series: U.S. Geological Survey water-supply

paper ; 2248.

GB1027.U38H64 1985 


\title{
CONTENTS
}

\author{
Abstract 1 \\ Introduction 2 \\ Physical setting 2 \\ Physiography 2 \\ Climate 2 \\ General geology 4
}

Ground water $\mathbf{6}$

Alluvial aquifers 6

Recharge 7

Leakage from consolidated-rock aquifers 7

Infiltration from streamflow 7

Movement 8

Storage 8

Discharge 8

Springs 8

Evapotranspiration 9

Wells 11

Subsurface flow to consolidated-rock aquifers $\mathbf{1 1}$

Quality 12

Chemical and physical characteristics 12

Mass-transfer model 15

Bird's-nest aquifer 21

Recharge 22

Infiltration from Evacuation Creek 22

Downward leakage from the Uinta Formation 22

Movement 22

Storage 22

Discharge 22

White River 22

Upward leakage to Bitter Creek 22

Digital-computer model of flow system $\mathbf{2 2}$

Design 23

Calibration 26

Simulated effects of oil-shale development $\mathbf{2 6}$

Dewatering 26

Reservoir construction $\mathbf{2 6}$

Quality 30

Water supply $\mathbf{2 7}$

Chemical and physical characteristics $\mathbf{3 0}$

Mass-transfer model 32

Douglas Creek aquifer 33

Recharge $\mathbf{3 4}$

Precipitation 34

Infiltration from streams $\mathbf{3 5}$

Movement 35

Storage 35

Discharge 35

Springs in the outcrop area of the aquifer $\mathbf{3 5}$

Seepage to the White and Green Rivers and major tributaries 35

Wells 35 
Ground water-Continued

Douglas Creek aquifer-Continued

Digital-computer model of flow system 35

Design 35

Calibration 37

Simulated effects of oil-shale development $\mathbf{3 7}$

Quality 37

Chemical and physical characteristics $\mathbf{3 7}$

Mass-transfer model $\mathbf{4 4}$

Summary 44

References cited $\mathbf{4 6}$

PLATE

1. Map showing ground-water and surface-water monitoring sites in the southeastern Uinta Basin, Utah and Colorado (in pocket)

\section{FIGURES}

1. Map showing location of study area and proposed areas of oil-shale mining, 19793

2. Diagrams showing well- and spring-numbering systems used in Utah and Colorado 4

3. Diagrammatic geohydrologic section of part of the southeastern Uinta Basin showing direction of ground-water movement 6

4. Hydrographs showing fluctuations of water levels in three observation wells completed in alluvial aquifers 9

5. Map and diagrams showing variation in mean dissolved-solids concentrations and chemical character of water in the alluvial aquifers $\mathbf{1 4}$

6-10. Graphs showing:

6. Variation of sodium with chloride in water from the Bitter Creek alluvial aquifer $\mathbf{1 6}$

7. Variation of calcium with chloride in water from the Bitter Creek alluvial aquifer 17

8. Variation of alkalinity with chloride in water from the Bitter Creek alluvial aquifer 18

9. Variation of magnesium with chloride in water from the Bitter Creek alluvial aquifer 18

10. Variation of sulfate with chloride in water from the Bitter Creek alluvial aquifer 19

11. Hydrographs showing relation of water levels in wells (D-10-24) 20add-2 and (D-10-24)12cda-1, corrected for changes in barometric pres-

12-17. Maps showing: sure, to discharge of the White River at gaging station $09306500 \mathbf{2 3}$

12. Aquifer boundaries, grid size, constant-head nodes, and leakage nodes used in the digital-computer model of the bird's-nest aquifer $\mathbf{2 4}$

13. Hydraulic conductivity and storage coefficient of the birds'-nest aquifer used in the digital-computer model $\mathbf{2 5}$

14. Potentiometric-surface contours of the bird's-nest aquifer computed by the digital-computer model 27

15. Distribution of recharge and discharge, computed by the digitalcomputer model for the bird's-nest aquifer $\mathbf{2 8}$

16. Drawdown in bird's-nest aquifer after 20 years of simulated withdrawals, computed by the digital-computer model 29

17. Variation in mean dissolved-solids concentrations and chemical character of water in part of the bird's-nest aquifer $\mathbf{3 1}$ 
18. Graph showing a plot of alkalinity versus sulfate in water from the bird'snest aquifer showing the reaction path calculated by the masstransfer model 34

19. Graph showing plot of $\mathrm{pH}$ versus chloride in the bird's-nest aquifer showing the reaction path calculated by the mass-transfer model $\mathbf{3 4}$

20-25. Maps showing:

20. Aquifer boundaries, grid size, and leakage nodes used in the digitalcomputer model of the Douglas Creek aquifer $\mathbf{3 6}$

21. Transmissivity of the Douglas Creek aquifer used in the digitalcomputer model $\mathbf{3 8}$

22. Potentiometric-surface contours of the Douglas Creek aquifer, computed by the digital-computer model 39

23. Distribution of recharge and discharge, computed by the digitalcomputer model for the Douglas Creek aquifer $\mathbf{4 0}$

24. Drawdown in the Douglas Creek aquifer after 20 years of simulated withdrawals. computed by the digital-computer model $\mathbf{4 1}$

25. Variation in mean dissolved-solids concentrations and chemical character of water in the Douglas Creek aquifer $\mathbf{4 2}$

26. Graph showing a plot of alkalinity versus sulfate in the Douglas Creek aquifer showing the reaction path calculated by the mass-transfer model 45

\section{TABLES}

1. General lithologic character and water-bearing properties of exposed geologic units 5

2. Summary of ground-water budget for alluvial aquifers 7

3. Summary of estimated ground-water storage and recoverable water in storage in alluvial aquifers $\mathbf{8}$

4. Summary of evapotranspiration by phreatophytes from alluvial aquifers $\mathbf{1 1}$

5. Summary of chemical quality of water in the major alluvial aquifers $\mathbf{1 2}$

6. Summary of mass-transfer model of the Bitter Creek alluvial aquifer $\mathbf{2 0}$

7. Summary of ground-water budget for the bird's-nest aquifer $\mathbf{2 1}$

8. Summary of chemical quality of water in the bird's-nest aquifer $\mathbf{3 2}$

9. Summary of mass-transfer model of the bird's-nest aquifer $\mathbf{3 3}$

10. Summary of ground-water budget for the Douglas Creek aquifer 35

11. Summary of chemical quality of water in the Douglas Creek aquifer $\mathbf{4 3}$

12. Summary of mass-transfer model of the Douglas Creek aquifer 45 


\section{Metric Conversion Factors}

Most values in this report are given in inch-pound units. Conversion factors to metric units are shown below.

\begin{tabular}{lcl}
\hline Multiply & By & To obtain \\
\hline Acre & 0.4047 & Square hectometer \\
Acre-foot & 0.004047 & Square kilometer \\
& 0.001233 & Cubic hectometer \\
Barrel & 1233 & Cubic meter \\
Cubic foot & 0.1590 & Cubic meter \\
per second & 0.02832 & Cubic meter \\
Foot & & per second \\
Foot per day & 0.3048 & Meter \\
Foot per mile & 0.3048 & Meter per day \\
Foot per second & 0.1894 & Meter per kilometer \\
Foot squared & 0.3048 & Meter per second \\
per day & 0.0929 & Meter squared \\
Gallon & & per day \\
Gallon per & 3.785 & Liter \\
minute & 0.003785 & Cubic meter \\
Inch & 0.06309 & Liter per \\
Mile & 25.40 & second \\
Micromhos per & 2.540 & Millimeter \\
centimeter at & 1.609 & Centimeter \\
$25^{\circ}$ Celsius & 1.000 & Kilometer \\
Square mile & & Microsiemens per \\
\hline
\end{tabular}

Chemical concentration is given only in metric units; milligrams per liter or micrograms per liter. Milligrams per liter is a unit expressing the concentration of chemical constituents in solution as weight (milligrams of constituent per unit volume (liter) of water. One thousand micrograms per liter is equivalent to 1 milligram per liter. For concentrations less than 7.000 milligrams per liter, the numerical value is about the same as for concentrations in parts per million.

Chemical concentration in terms of ionic interaction values is given in milliequivalents per liter. Milliequivalents per liter is numerically equal to equivalents per million.

Water temperature is given in degrees Celsius $\left({ }^{\circ} \mathrm{Cl}\right.$, which can be converted to degrees Fahrenheit $\left({ }^{\circ} \mathrm{F}\right)$ by the following equation:

${ }^{\circ} \mathrm{F}=1.8\left({ }^{\circ} \mathrm{C}\right)+32$.

National Gendetic Vertical Datum of $1929(N G V D$ of 1929$)$ : a geodetic datum derived from a general adjustment of the first-order level nets of hoth the United States and Canada, formerly called mean sea level. 


\title{
Ground Water in the Southeastern Uinta Basin, Utah and Colorado
}

\author{
By Walter F. Holmes and Briant A. Kimball
}

\section{Abstract}

The potential for developing oil-shale resources in the southeastern Uinta Basin of Utah and Colorado has created the need for information on the quantity and quality of water available in the area. This report describes the availability and chemical quality of ground water, which might provide a source or supplement of water supply for an oil-shale industry

Ground water in the southeastern Uinta Basin occurs in three major aquifers. Alluvial aquifers of small areal extent are present in valley-fill deposits of six major drainages. Consolidated-rock aquifers include the birds's-nest aquifer in the Parachute Creek Member of the Green River Formation, which is limited to the central part of the study area; and the Douglas Creek aquifer, which includes parts of the Douglas Creek Member of the Green River Formation and parts of the intertonguing Renegade Tongue of the Wasatch Formation; this aquifer underlies most of the study area.

The alluvial aquifers are recharged by infiltration of streamflow and leakage from consolidated-rock aquifers. Recharge is estimated to average about 32,000 acre-feet per year. Discharge from alluvial aquifers, primarily by evapotranspiration, also averages about 32,000 acre-feet per year. The estimated volume of recoverable water in storage in alluvial aquifers is about 200,000 acre-feet. Maximum vields to individual wells are less than 1,000 gallons per minute.

Recharge to the bird's-nest aquifer, primarily from stream infiltration and downward leakage from the overlying Uinta Formation, is estimated to average 670 acre-feet per year. Discharge from the bird's-nest aquifer, which is primarily by seepage to Bitter Creek and the White River, is estimated to be at 670 acre-feet per year. The estimated volume of recoverable water in storage in the bird's-nest aquiter is 1.9 million acre-feet. Maximum yields to individual wells in some areas may be as much as 5,000 gallons per minute.

A digital-computer model of the flow system was used to evaluate the effects of oil-shale development on the bird's-nest aquifer at the Federal lease tracts $U_{a}$ and Ub. Results of model simulations indicate that during construction of a vertical access shaft, a pumping rate of about 900 gallons per minute would be required to dewater the aquifer. The model also indicates that the construction of a proposed reservoir on the White River may raise water levels in the bird's-nest aquifer near the reservoir site by as much as 45 feet.

The flow model was used to evaluate the potential ground-water supply available for oil-shale development in the vicinity of the Federal lease tracts $U$ a and Ub. The results of the simulation indicate that bird's-nest aquifer could supply about 10,000 acre-feet of water per year at that site, for a period of 20 years. Downdraw after 20 years of pumping would exceed 250 feet near the simulated well field. Based on the results of the model simulation, it is estimated that the aquifer could simultaneously supply another 10,000 acre-feet of water per year in the northern part of the study area, but some interference between well fields could be expected

The Douglas Creek aquifer is recharged by precipitation and stream infiltration at an average rate of about 20.000 acre-feet per year. Discharge is estimated to be about the same and is primarily through springs and diffuse seepage. The estimated volume of recoverable water in storage is 16 million acre-feet. Maximum yields to individual wells are estimated to be less than 500 gallons per minute.

A model of the flow system in the Douglas Creek aquifer indicates that the aquifer could supply about 700 acre-feet of water per year for oil-shale development at Federal lease tracts $\cup a$ and $U b$ and at the TOSCO Corp. site. After 20 years of pumping, water levels in production wells would be near the base of the aquifer. Based on the results of the model simulation, it is estimated that the aquifer could supply another 700 acre-feet of water per year in the southern part of the modeled area, but some interference between wells could be expected.

Chemical quality of the ground water in the southeastern Uinta Basin varies considerably. Water from alluvial wells ranges from about 440 to 27,800 milligrams per liter of dissolved solids. Water from two consolidated-rock aquiters has dissolved-solids concentrations ranging from 870 to 5,810 milligrams per liter in the bird's-nest aquifer, and from 640 to 6,100 milligrams per liter in the Douglas Creek aquifer. Water from alluvial wells generally is a sodium sulfate type, whereas water in both the consolidated-rock aquifers generally changes from a sodium sulfate type to a sodium bicarbonate type. All ground water is very alkaline, and the alluvial aquifers contain very hard water. None of the water is suitable for public supply, but all the water could be used for industrial purposes such as washing and cooling.

Changes in chemical composition of the ground water can be attributed to several physiochemical processes, including mineral precipitation and dissolution, oxidation and reduction, mixing, ion exchange, and evaporative concentration. Mass-transfer modeling of these processes shows how they can account for the variability in the ground-water quality. The mass-transfer model of the Bitter Creek alluvial aquifer shows that evaporative concentration, combined with precipitation of calcite, dolomite, gypsum, and release of carbon dioxide to the atmosphere results in the documented changes in the $\mathrm{pH}$ and dissolved solids in the water. The water-quality changes in the consolidated-rock aquifers 
are a result of precipitation of calcium carbonate and perhaps dolomite (calcium magnesium carbonate) with the reduction of sulfate by organic carbon, as well as ion exchange of magnesium for sodium. These processes result in large values of $\mathrm{pH}$ and alkalinity in the water.

\section{INTRODUCTION}

The increased demand for oil has renewed interest in developing the oil shale of the southeastern Uinta Basin, Utah and Colorado, which has been reported to contain more than 53 billion barrels of oil (Cashion, 1967. p. 1). The potential for developing the oil shale has created the need for information on the quantity and quality of water in the area. As a result, the U.S. Geological Survey began a comprehensive study of water resources in the southeastern Uinta Basin in October 1974 , in cooperation with the U.S. Bureau of Land Management and the Utah Department of Natural Resources, Division of Water Rights. This report, as one product of the comprehensive study, describes the availability and chemical quality of ground water, which might provide a source of supplement of water supply for an oil-shale industry. The location of the study area and proposed areas of oil-shale mining as of 1979 are shown in figure 1 .

To achieve the objectives of the study, 6 deep wells and 33 shallow wells were drilled, in which water levels were measured and from which samples for chemical analyses were obtained during 1976, 1977, and 1978. Additional data were obtained from 37 existing wells and 39 springs during the same period. The location of ground-water and selected surfacewater monitoring sites in the southeastern Uinta Basin are shown on plate 1. The chemical and hydrologic data obtained during the study are given in Conroy and Fields (1977), Conroy (1979 and i980). Holmes (1980). VTN, Colorado, Inc. (1977). and White River Shale Project (undated).

All the well-, spring-, and surface-water data sites mentioned in this report are identified by site numbers as used in the following reports containing the data collected at those sites: Conroy and Fields (1977), Conroy (1979, 1980), and Holmes (1980). The system of numbering wells and springs is based on the cadastrai land-survey system of the U.S. Government. The number, in addition to designating the well or spring, describes its position in the land net. By the landsurvey system. Utah is divided into four quadrants by the Salt Lake base line and meridian, and these quadrants are designated by the uppercase letters A. B, C, and D, indicating the northeast, northwest, southwest, and southeast quadrants, respectively. Numbers designating the township and range (in that order) follow the quadrant letter, and all three are enclosed in parentheses. The number after the parentheses indicates the section and is followed by three letters indicating the quarter section, the quarter-quarter section, and the quarter-quarter-quarter section-generally 10 acres. ${ }^{1}$ the letters $a, b, c$, and $d$ indicate, respectively, the northeast,

'Although the basic land unit. the section. is theoretically 1 square mile, many sections are irregular. Such sections are subdivided into 10-acre tracts. generally beginning at the southeast corner, and the surplus or shortage is taken up in the tracts along the north and west sides of the section. northwest, southwest, and southeast quarters of each subdivision. The number after the letters is the serial number of the well or spring within the 10-acre tract; the letter $S$ preceding the serial number denotes a spring. If a well or spring cannot be located within a 10-acre tract, one or two location letters are used and the serial number is omitted. Thus, (D-10-22) 10ada-1 designates the first well constructed or visited in the $\mathrm{NE}^{1 / 4} \mathrm{SE}^{1 / 4} \mathrm{NE}^{1 / 4}$ sec. 10. T. 10 S., R. 22 E., and (D-15-24) 10bcd-S1 designates a spring in the $\mathrm{SE}^{1 / 4} \mathrm{SW} 1 / 4 \mathrm{NW}^{1 / 4} \mathrm{sec} .10$. T. $15 \mathrm{~S}$., R. $24 \mathrm{E}$. For sites located in half townships, the letter $\mathrm{T}$ precedes the spring or well number. Thus. T(D-15-21)36adc-S1 designates a spring in $\mathrm{T}$. $15 \frac{1}{2} \mathrm{~S}$. The numbering system is illustrated in figure 2 .

In Colorado, the well- and spring-numbering system also is based on the cadastral land-survey system, and in the Uinta Basin area the system is referenced to the base line and the Sixth principal meridian and is identified by the prefix letter $\mathrm{S}$. Thus, spring $\mathrm{S}(\mathrm{C}-5-104) 27 \mathrm{dad}-\mathrm{S} 1$ is in the $\mathrm{SE} 1 / 4 \mathrm{NE} 1 / 4 \mathrm{SE} 1 / 4 \mathrm{sec}$. 27. T. 5 S., R. 104 W.. Sixth principal meridian (fig. 2). In Colorado records, springs are not identified by the letter $S$ preceding the serial number; but in this report. springs are so designated in order to, clearly identify the nature of the water source.

Records of streamflow at gaging stations are listed in downstream order. Station numbers are designated by the Geological Survey for regular streamflow stations. Waterquality and sediment stations operated at the streamflowgaging stations are assigned the same number.

\section{PHYSICAL SETTING}

\section{Physiography}

The southeastern Uinta Basin has an area of approxjmately 3.000 square miles in Utah and Colorado (plate 1). The White River and Willow Creek, tributaries of the Green River. drain most of the area. These drainages intersect a broad plateau to form benchlike mesas. The altitude of the land surface at its lowest point in the study area, on the Green River in Desolation Canyon, is about 4.600 feet ahove the National Geodetic Vertical Datum of 1929. The land surface gently rises to the south, reaching a maximum altitude of about 9.500 feet in the Roan Cliffs at the southern edge of the study area. Willow Creek and the tributaries of the White River trend northerly, forming steep-walled canyons 500 to 1,000 feet deep and as much as 5.500 feet wide, making travel difficult throughout the area.

\section{Climate}

At lower altitudes the climate of the basin is semiarid, with hot, dry summers and occasional intense thunderstorms. Higher altitudes have a subhumid climate. Normal annual precipitation (1941-70) ranges from about 8 inches at lower altitudes to ahout 20 inches in the Roan Cliffs to the south (Waltemeyer, 1982. pl. 1). Winters are cold, but snow generally accumulates only at altitudes above 6,000 feet, with subsequent spring runoff from snowmelt. At lower altitudes, in northern part of the area, a single summer thunderstorm may account for the entire yearly discharge of a small ephemeral stream. 

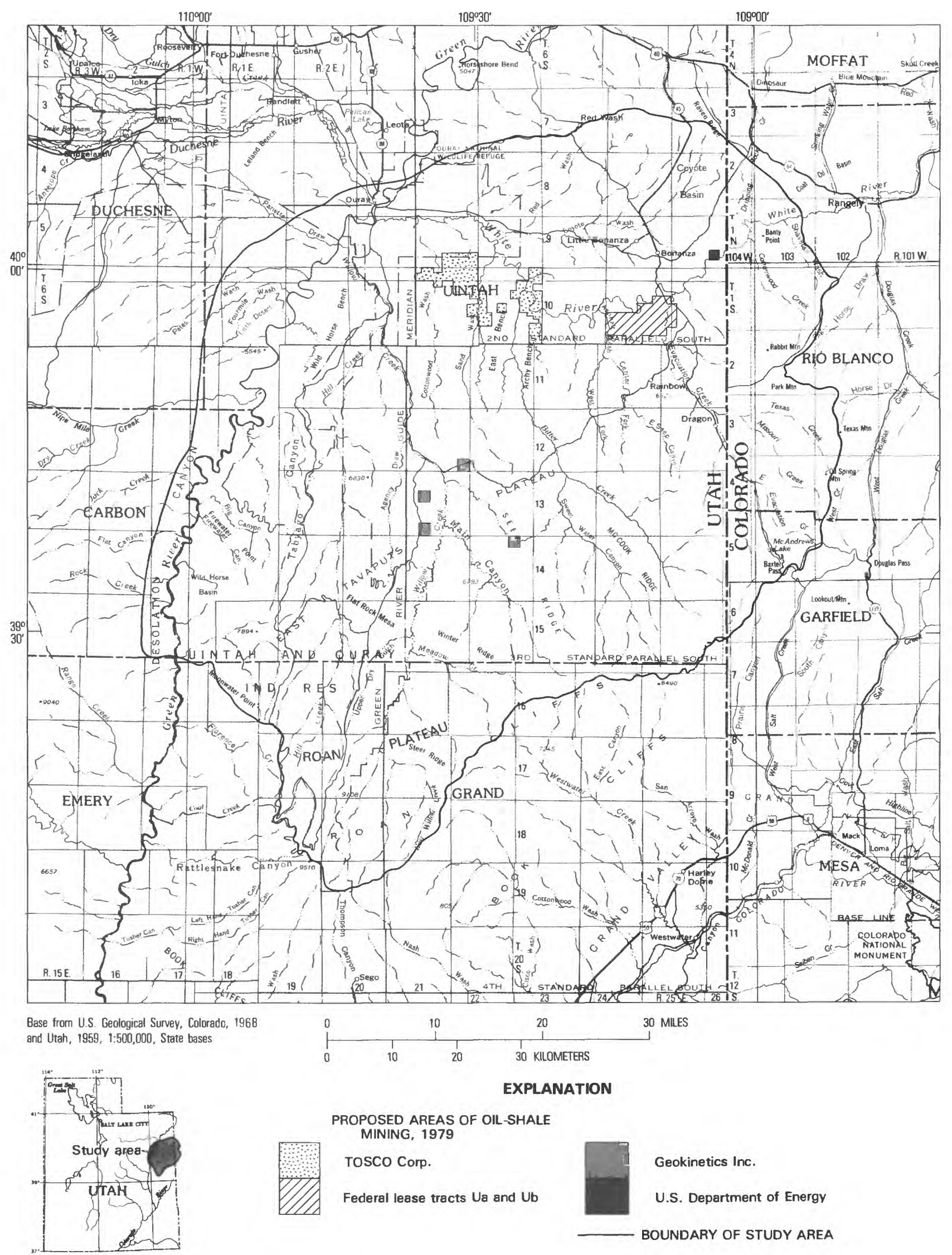

EXPLANATION

PROPOSED AREAS OF OIL-SHALE MINING, 1979

TOSCO Corp.

Federal lease tracts $U_{a}$ and $U b$

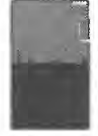

Geokinetics Inc.

U.S. Department of Energy

BOUNDARY OF STUDY AREA

Figure 1. Location of study area and proposed areas of oil-shale mining, 1979. 


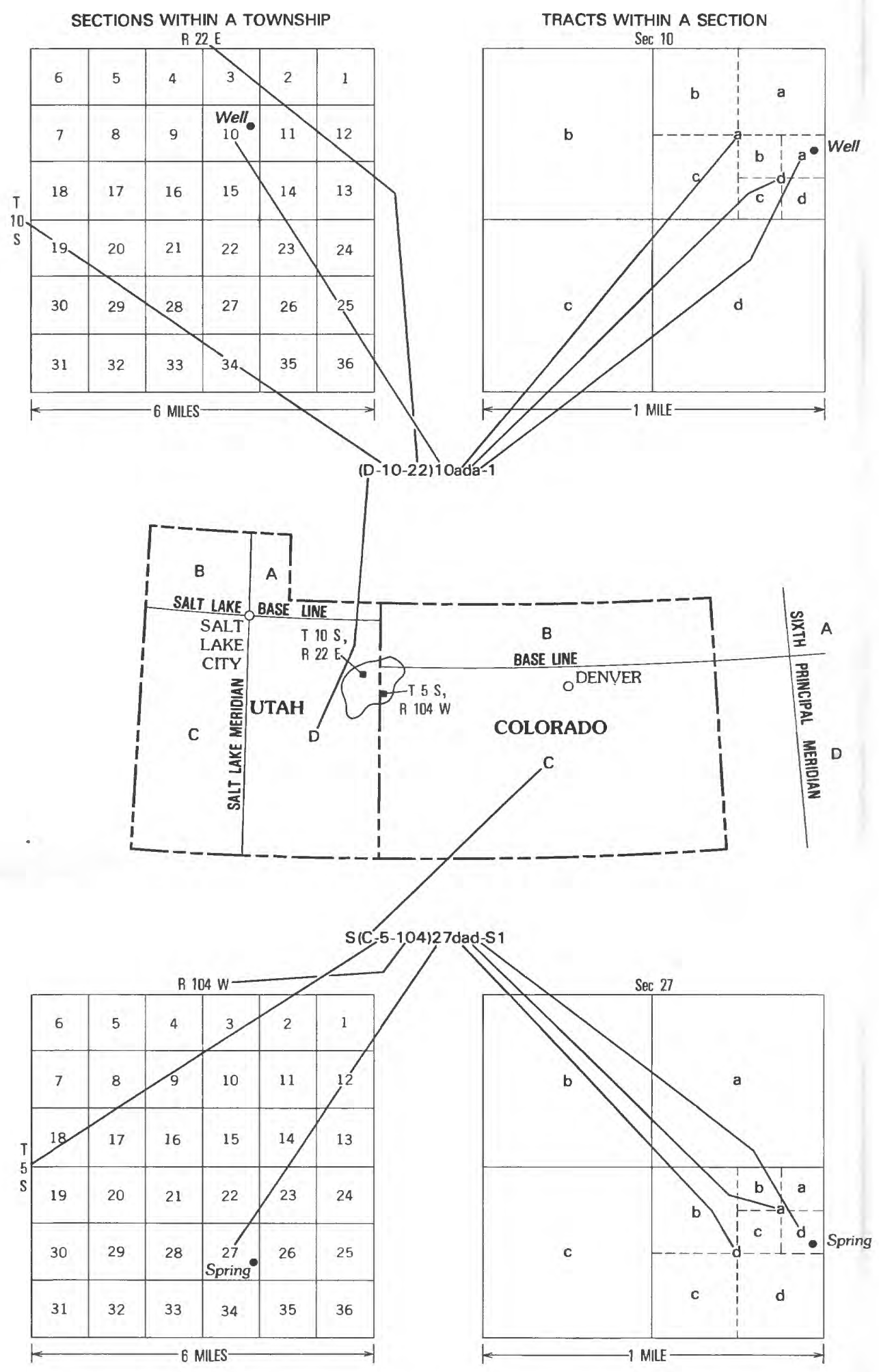

Figure 2. Well- and spring-numbering systems used in Utah and Colorado.

\section{General Geology}

The Uinta Basin contains a thick sequence of sedimentary rocks ranging in age from Precambrian to Tertiary. Osmond (1965) presents a review of the entire sequence. The rocks that are exposed in the southeastern Uinta Basin have been described by Cashion (1967). Only the exposed rocks will be discussed here. The lithologic and water-bearing properties of the geologic units exposed in the study area are summarized in table 1. The Tertiary rocks were deposited in a lake and by the 
Table 1. General lithologic character and water-bearing properties of exposed geologic units

\begin{tabular}{lcccc}
\hline Geologic age & Geologic unit & $\begin{array}{c}\text { Thickness } \\
\text { (teet) }\end{array}$ & Lithologic character & General water-bearing properties \\
\hline & $\begin{array}{c}\text { Lnconsolidated } \\
\text { alluvial deposits }\end{array}$ & $0-150$ & Alluvium, fluvial deposits. Clays, silt, & Yield less than 1.000 gallons per min- \\
Quaternary & & sand, and some gravel. Caliche & ute. Locally saturated in major \\
& & & always found near water table. & drainages, with slow movement of \\
& & Clays predominantly illite and & water. \\
& & & illite-smectite.
\end{tabular}

$\begin{array}{ccc}\text { Uinta Formation } & 0-5.000 \quad \begin{array}{c}\text { Fluvial deposits of mostly thinly- } \\ \text { bedded siltstone, and fine-grained } \\ \text { sandstone. Some beds of volcanic } \\ \text { tuff cut in several places by gilson- } \\ \text { ite veins. }\end{array} \\ \begin{array}{c}\text { Parachute Creek } \\ \text { Member of the }\end{array} & \begin{array}{l}\text { Lacustrine deposits of thinly-bedded } \\ \text { claystone, siltstone (both called }\end{array} \\ \text { Formation } & \text { marlstonel, fine-grained sandstone. } \\ & \begin{array}{l}\text { limestone and some tuff. Contains } \\ \text { prominent oil-shale deposits. Clays } \\ \text { are illite and trioctahedral smectite. } \\ \text { Local cavities of evaporite minerals, } \\ \text { mainly nahcolite. Laterally con- } \\ \text { tinuous. }\end{array}\end{array}$

Tertiary

Douglas Creek
Member of the
Green River
Formation

2(0)-1.300 Predominantly marginal lacustrine deposits of claystone, siltstone (n)arlstone), fine-grained sandstone. and limestone. Six tongues have been identified by Cashion 1967 . p. 6-71. Clays mostly smectite and illite. Channel-form sandstone common. Beds commonly are discontinuous.
Renegade Tongue of the Wasatch Formation

0-1.000 Fluvial deposits of massive. irregularly-bedded sandstone and red and gray siltstone inter-tonguing with Douglas Creek Member of Green River Formation. Clays are smectite, illite. mixed layer chlorite and kaolinite.
Not water-bearing in many areas where deeply incised by streams. Commonly yields less than 5 gallons per minute to springs.

Overall permeability is minimal. Springs generally yield less than 10 gallons per minute. Wells associated with fractures may yield as much as 5.000 gallons per minute. according to model simulation. Contains bird's-nest aquifer locally. Equivalent to the bird's-nest zone of Cashion (1967).

Permeability varies. Springs yielding as much as 50 gallons per minute discharge from sandstone. Contains several water-yielding beds that are part of the Douglas Creek aquifer, which yields $40-500$ gallons per minute to wells.

More permeable than Green River Formation. Springs yield as much 200 gallons per minute. Constitutes part of the Douglas Creek aquifer. rivers that flowed into it. Bradley $11929,1931.1948$, and 1964: Bradley and Eugster. 1969) has been foremost in describing the depositional history of the lake. which he named Lake Uinta (Bradley, 1929, p. 88). During the Eocene Epoch. Lake Uinta increased in size and finally receded, leaving a lens of lacustrine deposits surrounded by fluvial deposits. The lake changed in size and shape many times: and as a result, the lacustrine deposits also interfinger with the fluvial deposits. This interfingering between the lacustrine Green River Formation and the fluvial Wasatch Formation is shown in figure 3.

The general depositional setting of the Tertiary rocks has been divided into three main environments. Picard and High (1972, p. 2705) have classified these environments as fluvial. fluvial and lacustrine-deltaic, and lacustrine deep-water. This general depositional history resulted in primarily fluvial sandstone in the southern part of the area. grading to siltstone and marlstone of the lacustrine deep-water environment in the north.

The fluvial and much of the fluvial-deltaic environments are represented by the Wasatch Formation, particularly the Renegade Tongue, shown in figure 3 . The rocks of the Renegade Tongue are mostly massive channel-filling sandstone and siltstone from the river flood plains. These rocks reach a maximum thickness of 1.000 feet at the southern boundary of the study area, they thin to less than 100 feet in the vicinity of Bitter Creek near well (D-13-23)26bdc-1 (pl.1). and they disappear to the north. The lacustrine-deltaic environment and some of the fluvial-deltaic environments are represented by the Douglas Creek Member of the Green River Formation and parts of the Parachute Creek Member of the Green River Formation, which consist of sandstone, marlstone isiltstone and claystone). and algal and oolitic limestone. The lacustrine 


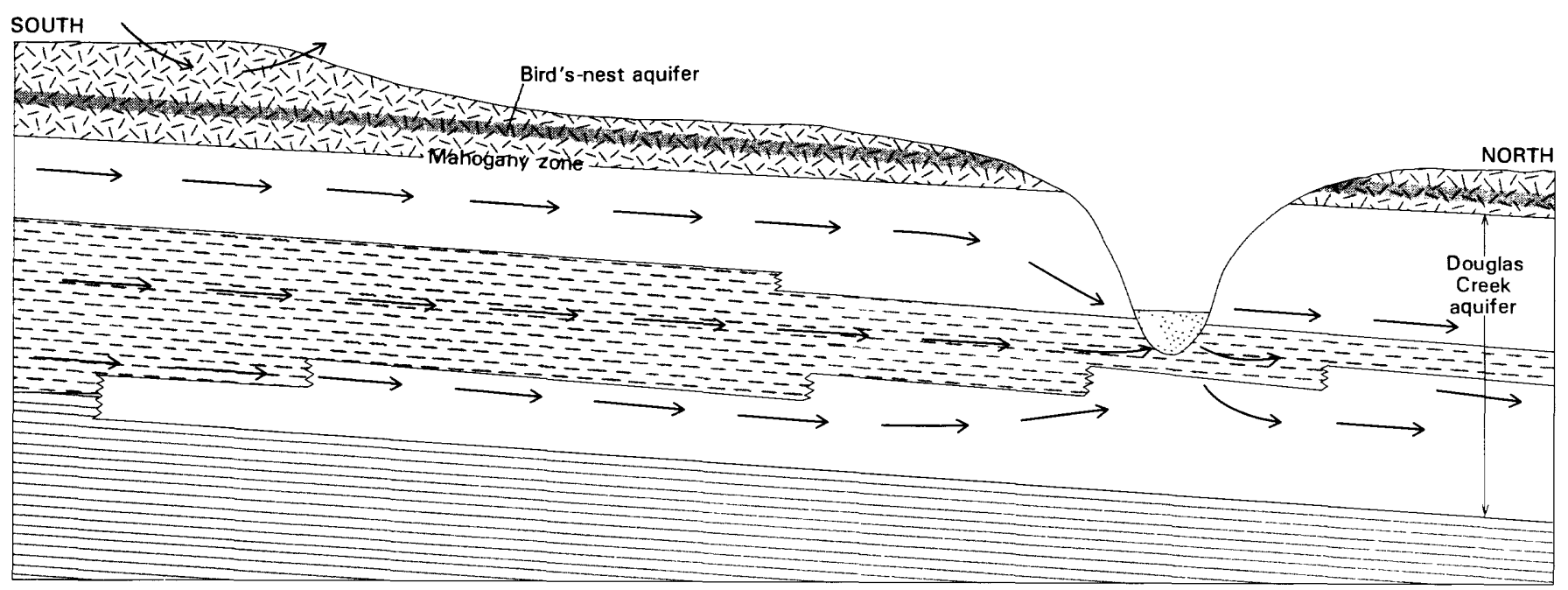

VERTICAL SCALE EXAGgERATED

EXPLANATION

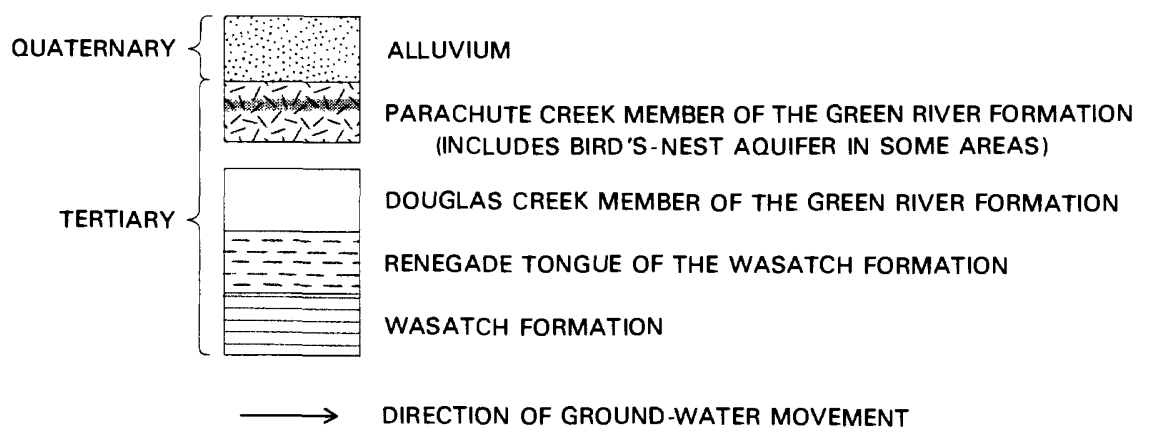

Figure 3. Diagrammatic geohydrologic section of part of the southeastern Uinta Basin showing direction of ground-water movement. (Geology adapted from Cashion, 1967.)

deep-water environment is represented mostly by the Parachute Creek Member, whose beds are marlstone, sandstone, and muddy limestone. The marlstone, which has a large magnesium content and in many places has a large organic content. comprises the "oil shale" of the Green River Formation.

After the deposition of organic-rich marlstone, Lake Uinta began to recede. The water became saline, and local deposition of evaporite minerals occurred. As the area of the lake decreased, fluvial deposits were laid down where the lake had previously been. These fluvial deposits belong to the Uinta Formation of Tertiary age. The siltstone, sandstone, and tuff that it contains are exposed in a large area near the White River in R. 20 through 24 E. of T. 9. 10, and 11 S.

Deposits of Quaternary alluvium are present along almost every drainage in the study area. In some of the larger drainages these deposits are more than 100 feet thick. They consist of material derived from the nearby Tertiary rocks, ranging in size from clay to gravel.

The exposed strata dip gently to the northwest at about $2^{\circ}$, and the entire section of the Green River Formation is exposed from south to north. Near the Douglas Creek arch at the Utah-Colorado border, the strata are upturned and dip about $30^{\circ}$ to the west (Cashion, 1967, p. 22). Some minor faults and a joint system occur in a northwest-trending direction. Gilsonite veins are found in some of the joints in part of the area ICashion, 1967. p. 231.

\section{GROUND WATER}

\section{Alluvial Aquifers}

Well data and water-level measurements for alluvial aquifers in the southeastern Uinta basin are reported by Conroy and Fields (1977, tables 7 and 10), Conroy 11979, tables 7 and 9), and Conroy (1980, table 8). Most of the aquifers are in valley fill consisting mainly of silt and clay, with minor amounts of sand and gravel. The aquifers are along the major drainages of Willow, Hill, Bitter, and Evacuation Creeks, and the White and Green Rivers. Minor drainages. such as Hells Hole Canyon and Cottonwood and Coyote Washes, contain alluvial aquifers hut their areal extent is small.

The thickness of the valley fill determined during test drilling in major drainages ranges from a minimum of 15 feet at well (D-10-24)13aca-1 to a maximum of 129 feet at well (D-13-19)13aad-1 (Conroy, 1979, table 7). The average thick- 
ness of fill in the Willow. Hill. and Bitter Creek drainages generally is about 100 feet. whereas the average thickness of the fill in Evacuation Creek, White River, and small tributaries is about 30 feet. The thickness of fill generally reaches a maximum near the midpoint of the major drainages.

Hydraulic conductivity and specific yield of alluvial aquifers in the southeastern Uinta Basin were estimated from descriptions of aquifer materials in published reports and from unpublished drillers logs. These estimates are based solely on particle sizes reported in the log descriptions. and are considered only as approximations.

Mower (1978. p. 16) estimated that the average hydraulic conductivity ( $K$ ) of alluvial aquifers similar to those found in the southeastern Uinta Basin ranged form 1 to 25 feet per day. Applying these results to the southeastern Uinta Basin. the largest values of $K$ occur in aquifers along the White and Green Rivers. where the valley fill consists of clay. silt. sand. and some gravel. The smaller values of $\mathrm{K}$ generally occur in aquifers along Willow. Hill, Bitter, and Evacuation Creeks where the valley fill consists of clay. silt. and some fine sand. The estimates of $K$ are somwhat less than the approximately 50 feet per day reported for similar aquifers in the Piceance Creek Basin, Colorado 1 Coffin and others, 1968, p. 17). This probably is due to the relatively large amounts of sand and gravel in the alluvial aquifers of the Piceance Creek Basin.

Johnson (1967, p. D70) reported an average range in specific yield $\left(S_{1}\right)$ in alluvial aquifers similar to those found in the southeastern Uinta Basin from 0.02 to 0.21. Applying these results to the southeastern Uinta Basin, the larger values of $S_{y}$ would be expected to occur in alluvial aquifers along the White and Green Rivers whereas the smaller values would be expected to occur in alluvial aquifers in Willow. Hill. Bitter. and Evacuation Creeks.

A summary of the ground-water budget for alluvial aquifers in the southeastern Uinta Basin is presented in table 2. Subsequent sections of this report discuss the budget elements in more detail.

\section{Recharge}

Recharge to alluvial aquifers originates from leakage from consolidated-rock aquifers and infiltration from streamflow. Precipitation falling on the alluvium averages less than 12 inches per year, and it probably is almost all consumed by evapotranspiration. Subsurface inflow across boundaries of the study area in alluvial aquifers along the White and Green Rivers is estimated to be equal to subsurface outflow across boundaries of the study area along the Green River.

\section{Leakage from Consolidated-Rock Aquifers}

Leakage from underlying consolidated rocks occurs where aquifers in the Uinta and Green River Formations are in contact with alluvial aquifers. The amount of water recharging alluvial aquifers from consolidated-rock aquifers was estimated by ground-water models to be about 2.000 acre-feet per year.

\section{Infiltration from Streamflow}

Infiltration from streams occurs in the southern part of the study area along the perennial and intermittent reaches of the major tributaries and along the White and Green Rivers. Maximum infiltration probably occurs during summer months and during periods of snowmelt. During the summer, evapotranspiration by phreatophytes lowers water tables adjacent to streams. During periods of snowmelt, the hydraulic head is greatest in the streams and the sediment on the stream bottom is disturbed by the turbulent flow. All these factors tend to increase the amount of infiltration.

Recharge to alluvial aquifers by infiltration from streams was estimated by a water-budget analysis. The alluvial aquifers in the southeastern Uinta Basin are under steady-state conditions.

Table 2. Summary of ground-water budget for alluvial aquifers

\begin{tabular}{|c|c|}
\hline Component & $\begin{array}{l}\text { Long-term average } \\
\text { (acre-feet per vear) }\end{array}$ \\
\hline \multicolumn{2}{|l|}{ Recharge: } \\
\hline Leakage from consolidated-rock aquifers & 2.000 \\
\hline Infiltration from streamflow & 30,000 \\
\hline Infiltration of precipitation & Insignificant \\
\hline Inflow across boundaries of the study area & $\begin{array}{c}\text { Assumed to equal outflow across } \\
\text { boundaries of the study area. }\end{array}$ \\
\hline Total & .32 .000 \\
\hline \multicolumn{2}{|l|}{ Discharge: } \\
\hline Springs & 600 \\
\hline Evapotranspiration & 28.000 \\
\hline Wells & 1.000 \\
\hline Subsurface flow to consolidated aquifers & 2.000 \\
\hline Outflow across boundaries of the study area & $\begin{array}{l}\text { Assumed to equal inflow across } \\
\text { boundaries of the study area. }\end{array}$ \\
\hline Total & 32.000 \\
\hline
\end{tabular}


and over a long time the recharge should equal the discharge. A total discharge of about 32,000 acre-feet per year is shown in table 2. The difference between the total discharge and the recharge form consolidated-rock aquifers amounts to 30,000 acre-feet per year, and this is considered the amount of recharge from infiltration of streamflow.

\section{Movement}

Water in alluvial aquifers moves from recharge areas along perennial reaches of streams at high altitudes downstream toward the mouths of major drainages. Most of the water is consumed by evapotranspiration (table 2) along the stream channels and never reaches the mouths of major drainages. The rate of water movement is slow due to the minimal permeability of the fine-grained alluvial material. Water-level gradients in major drainages average about 40 feet per mile and the average velocity of water moving through alluvial aquifers is about 0.4 foot per day.

\section{Storage}

The volume of water stored in alluvial aquifers in the southeastern Uinta Basin is estimated to be 675.000 acre-feet. This estimate is based on: (1) An areal extent of about 38,000 acres: (2) a saturated thickness based on water levels in test holes drilled to the base of the alluvium (Conroy and Fields. 1977. tables 7 and 9; Conroy, 1979, tables 7 and 9): and (3) a porosity of 30 to 59 percent estimated from lithologic descriptions by drillers (Mower and Cordova. 1974, p. 27 ).

The volume of recoverable water is a function of the specific yield. By multiplying the specific yield by the volume of saturated alluvial deposits, it is estimated that the total amount of water that is theoretically recoverable from storage is 200,00 acre-feet. The estimated volume of water stored and the estimated recoverable water in storage in the southeastern Uinta Basin are shown in table 3.

Fluctuations in water levels represent changes in groundwater storage. In the southeastern Uinta Basin, where little ground-water development has taken place, these fluctuations virtually are due to seasonal variations in the balance between recharge and discharge.

Observation wells completed in alluvial aquifers at or near recharge areas at high altitudes in the southern part of the study area. where recharge is derived primarily from infiltration of streamflow, show large seasonal fluctuations in water levels. The hydrograph of well (D-13-24)18bbb-1 in the Bitter Creek drainage shows a fluctuation of more than 20 feet (fig. 4 ).

Observation wells completed in alluvial aquifers near the mouths of major tributaries show small seasonal fluctuations in water levels. The hydrograph of well (D-10-22) 10ada-1 (fig. 4 ) shows a range in water levels of less than 2 feet. This well also is in the Bitter Creek drainage, but due to the distance from the recharge area, the magnitude of the fluctuations in water levels are small.

Water levels in observation wells completed in the alluvial aquifers along the White River show small seasonal fluctuations in water levels. The hydrograph of well ( D-10)-23123d dbd-1 (fig. 4 ) shows a fluctuation in water levels of about 3 feet.

\section{Discharge}

Water in alluvial aquifers is discharged by springs, evapotranspiration. wells, and subsurface flow into consolidated aquifers. Subsurface outflow across boundaries of the study area in alluvial aquifers along the Green River is estimated to be equal to subsurface inflow across boundaries of the study area in alluvial aquifers along the White and Green Rivers.

\section{Springs}

Alluvial aquifers discharge an estimated 600 acre-feet per year (table 21 at two springs along Bitter Creek. Spring (D-13-23).3chb-S1 (pl. 1) discharges about 160 acre-feet per year where valley-fill deposits are apparently constricted by narrow canyon walls. Spring (D-10-22)15ddc-S1 discharges about 440 acre-feet per year where valley-fill deposits decrease

Table 3. Summary of estimated ground-water storage and recoverable water in storage in alluvial aquifers

\begin{tabular}{|c|c|c|c|c|c|c|c|}
\hline $\begin{array}{c}\text { Drainage } \\
\text { hasın }\end{array}$ & $\begin{array}{l}\text { Area of } \\
\text { saturated } \\
\text { alluvial } \\
\text { deposits } \\
\text { (acres) } \\
\end{array}$ & $\begin{array}{l}\text { Average } \\
\text { thickness of } \\
\text { saturated } \\
\text { alluvial } \\
\text { deposits } \\
\text { (feet) }\end{array}$ & $\begin{array}{l}\text { Volume of } \\
\text { saturated } \\
\text { alluvial } \\
\text { deposits } \\
\text { (acre-feet) }\end{array}$ & $\begin{array}{c}\text { Estimated } \\
\text { average } \\
\text { porositv } \\
\text { (percent) }\end{array}$ & $\begin{array}{c}\text { Estimated } \\
\text { specitic } \\
\text { yield }\end{array}$ & $\begin{array}{c}\text { Volume of } \\
\text { water in } \\
\text { storage } \\
\text { (acre-teet) }\end{array}$ & $\begin{array}{c}\text { Volume of } \\
\text { recoverable } \\
\text { water in } \\
\text { storage } \\
\text { (acre-teet) }\end{array}$ \\
\hline Bitter Creek & 4.300 & 40 & 172,000 & 50 & 0.05 & 86,000 & 8.600 \\
\hline Evacuation Creek & 1.800 & 21 & 37.800 & 40 & .05 & 15.100 & 1.890 \\
\hline Green River & 9,200 & 30 & 276,000 & 30 & .20 & 82.800 & 55.200 \\
\hline Hill Creek & 7.400 & 88 & 651,000 & 30 & .10 & 195.000 & 65.100 \\
\hline White River & 6.100 & 32 & 195.000 & 30 & .20 & 58.500 & 39.000 \\
\hline Willow Creek & 9.600 & 62 & 595,000 & 40 & .05 & 238.000 & 29.800 \\
\hline $\begin{array}{l}\text { Total } \\
\quad \text { rounded }\end{array}$ & ed) & & 1.900 .000 & & & 675.000 & 200.000 \\
\hline
\end{tabular}



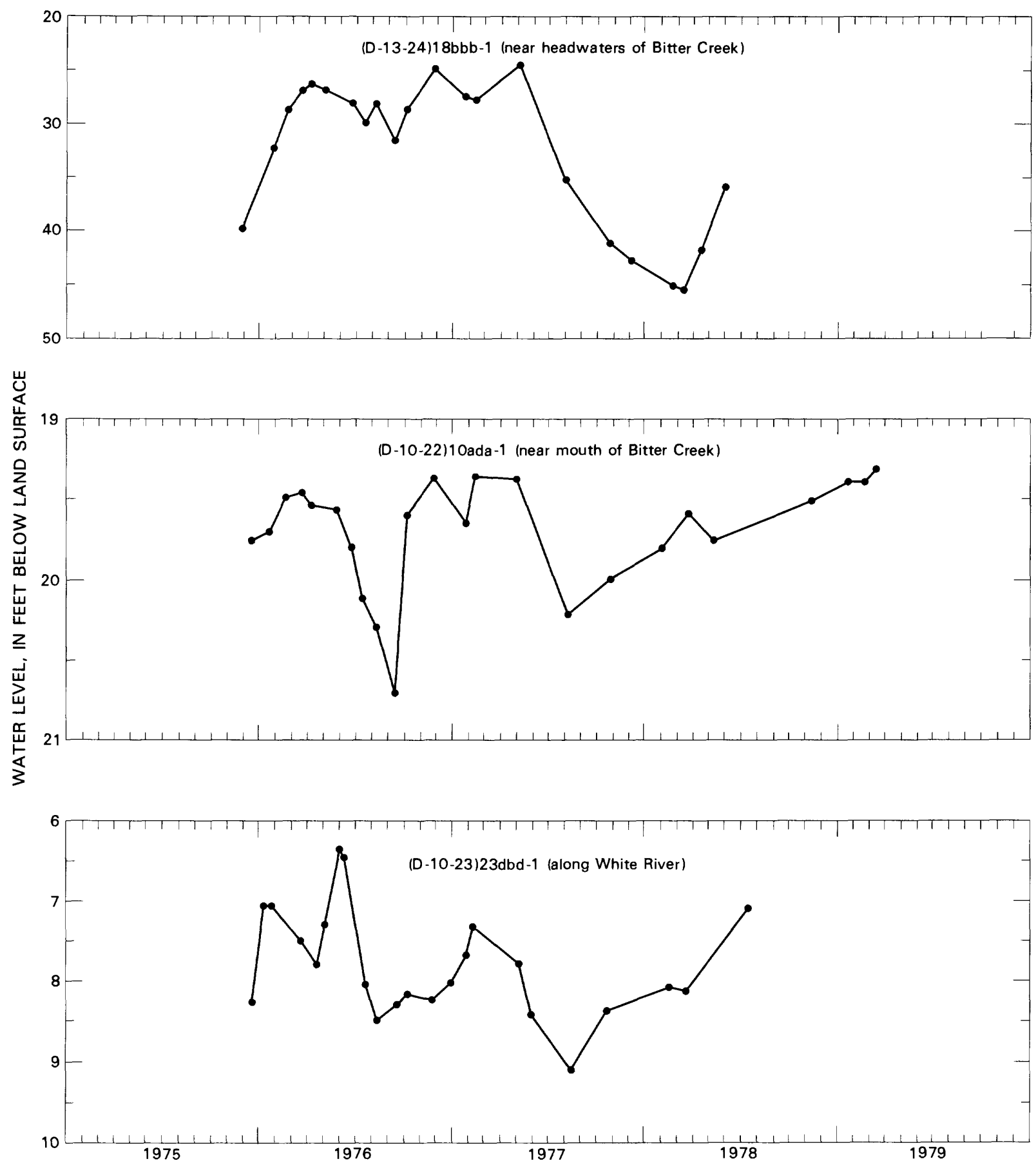

Figure 4. Fluctuations of water levels in three observation wells completed in alluvial aquifers.

- thickness. and where apparent inflow from consolidatedcek aquifers is transmitted through alluvial aquifers and is . scharged from the spring. Numerous other springs may - scharge some water: but the total amount probably is less han 50 acre-feet per year. and the discharge points are masked $\because$ perennial streamflow.

\section{Evapotranspiration}

Evapotranspiration in areas of phreatophytes is estimated to be 28,000 acre-feet per year. and it is the largest type of discharge form alluvial aquifers (table 2). Greasewood (Sarcobatus vermiculatus) is the most common phreatophyte 
and occurs throughout the study area along perennial, intermittent, and some ephemeral streams. Other important phreatophytes in the study area are saltcedar (Tamarix gallica). saltgrass (Distichlis stricta), willow (Salix sp.). rabbitbrush (Chrysothammus nauseosus), and cottonwood (Populus sp.).

A vegetation map (Butler and England. 1979) shows major concentrations of phreatophytes on the flood plains of the Green and White Rivers and along the perennial and intermittent reaches of Hill, Willow, Bitter, and Evacuation Creeks. Scattered greasewood and rabhitbrush grow in tributaries to these drainages and other small drainages in the area.

A method used by Mower and Nace (1957, p. 6) was modified and used in conjunction with the vegetation map, aerial photographs, and streamflow profiles on Bitter Creek (Lindskov and Kimball, 1982) to estimate evapotranspiration along Hill. Willow, Bitter. and Evacuation Creeks. Infrared aerial photographs on a scale of 1:31.680 were used to assign plane densities of 100,50 , or 10 percent for the phreatophyte areas classified as greasewood on the vegetation map. The densities taken from aerial photographs may differ from corresponding on-site measurements of volume density using the method outlined by Mower and Nace (1957. p. 6) because the height of the plant and the density of foliage cannot be measured from aerial photographs.

After assigning plant densities to all the phreatophyte areas, a typical reach between two streamflow-measurement sites in the Bitter Creek drainage was used to determine streamflow losses in relation to each density classification. The sample reaches used to evaluate streamflow losses were chosen in areas where gains or losses from consolidated rocks were expected to be minimal. where tributary inflow was insignificant. and where most of the vegetation was in one density classification.

The following summary shows how evapotranspiration was calculated for the Bitter Creek drainage basin:

Total area of Phreatophytes: 4.259 acres

Area at 100 -percent density $=765$ acres

Area at 50-percent density $=1.3,36$ acres

Area at 10 -percent density $=2.158$ acres

Calculation of streamflow losses at 100-percent density

Area between streamflow-measurement sites 09306790 and $09.306800=217$ acres

Streamflow loss in sample reach $=486$ acre-feet per year

Rate of evapotranspiration: 486 divided by $217=2.24$ feet per year

Total evapotranspiration from area of 100-percent density $=2.24 \times 765=1.714$ acre-feet per year

Calculation of streamflow losses at 50-percent density Area between streamflow-measurement sites $09.306 \times 00$ and $09.306820=727$ acres

Streamflow loss in sample reach $=246$ acre-feet per year

Rate of evapotranspiration: 246 divided by $727=0.34$ foot per year

Total evapotranspiration from area of 10-percent density $=0.05 \times 2.158=108$ acre-feet per year

Total evapotranspiration for area of 50)-percent density $=0.34 \mathrm{x} !, 336=4.54$ acre-feet per year

Calculation of streamflow losses at 10-percent density
Area between streamflow-measurement sites 09.306820 and $09.3068 .30=292$ acres

Streamflow loss in sample reach $=14$ acre-feet per year

Rate of evapotranspiration $=14$ divided by $292=0.05$ foot per year

Total estimated evapotranspiration for Bitter Creek drainage $=2.276$ acre-feet per year

The annual streamflow measured at station 09.306850 (Bitter Creek at mouth. near Bonanza. Utah) is ().8 cubic foot per second or 580 acre-feet per year (Lindskov and Kimball, 19821. Thus, the evapotranspiration in the Bitter Creek drainage basin from areas of phreatophytes exceeds the annual streanflow by about 400 percent. The rates calculated for each density classification in the Bitter Creek drainage also were used in the Willow. Hill. and Evacuation Creek drainages where phreatophytic vegetation is similar.

Evapotranspiration. in cubic feet per second. along the White River flood plain was estimated using low-flow records, in cubic feet per second. from August through Nowember 1975-79. at gaging stations $(19,3065(0)$ and 09.306900 (fig. 2). using the following relationsinip:

or

$$
Q+T+S i+P=E T+S_{0}
$$

where

$$
Q=E T+S_{O}-T-S i-P
$$

$Q=$ average discharge at station $(09.306 .500$ minus the average discharge at station 09306900 :

$T=$ tributary inflow between the two stations:

$S i=$ subsurface inflow from consolidated and unconsolidated rocks:

$S_{0}=$ subsurface outflow to consolidated and unconsolidated rocks;

$P=$ precipitation: and

$E T=$ evapotranspiration befween the two stations. Assuming:

1. ET is negligible during October and November:

2. $T$ is constant during August-November:

3. Si and $S o$ are constant during August-November: and

4. $P$ has no effect on streamflow during August-November. Then two equations result: and

$$
Q I=E T+S_{0}-T-S i \text { (for August and September) } 13 \text { ) }
$$

$Q 2=S_{0}-T-S_{i} \quad$ (for October and November). 14) Subtracting the two equations gives the following results:

$$
Q 1-Q 2=E T \text {. }
$$

Substituting values for 1975-79 1 Conroy and Fields. 1977; Conroy. 1979 and 198()):

$E T$ during August and September $=1.3-1-13)$ or 26 cubic feet per second.

Evaporation from the water surface of the White River averages about 6 cubic feet per second for August through November (S. D. Waltemeyer. U.S. Geological Survey, written commun., February 1, 1980). This leaves a total estimated discharge by evapotranspiration on the flood plain during August and September of about 20 cubic feet per second or 2,400 acre-feet. About 3.380 acres of the flood plain are covered by phreatophytes between the two stations. Therefore. the average rate of evapotranspiration for August and September 
is 0.71 foot or a daily rate of 0.012 foot. Assuming a 125-day growing season and an average rate of 0.012 foot per day, the annual rate of evapotranspiration is estimated to be 1.5 feet. Assuming 4.888 acres of phreatophytes on the flood plain of the White River (Butler and England, 1979), the total annual evapotranspiration is about 7.300 acre-feet.

The annual rate of evapotranspiration calculated for the White River flood plain also was applied to the flood plain of the Green River where vegetation species and densities are similar. Thomas (1952 p. 28) studied evapotranspiration from the flood plain of the Green River downstream from Ouray, Utah. The results of his study indicate a daily rate of evapotranspiration during September 1948 of 0.013 foot. This rate is in close agreement with the daily rate of 0.012 foot calculated during this study. Assuming 4,12() acres of phreatophytes on the flood plain of the Green River (Butler and England, 1979), the total annual average evapotranspiration is about 6,200 acre-feet.

A summary of the water lost through evapotranspiration from alluvial aquifers in the southeastern Uinta Basin is presented in table 4 . The density of phreatophytes on the flood plains of the White and Green Rivers is fairly consistent and no attempt was made to separate these areas into distinct density classifications in table 4 .

\section{Wells}

Discharge from wells completed in alluvial aquifers in the southeastern Uinta Basin is estimated to be about 1,(0)() acre-feet per year (Ronald Jibson. Utah Division of Water
Rights, written commun.. Fehruary 19, 1980). All the alluvial wells are along the White River near Bonanza, in T. 10 S., R. 24 E.. sec. 2 and they supply water for gilsonite-mining operations in the area. The depths of the wells range form 12 to 36 feet. and vields in individual wells range from 7 to 660 gallons per minute (Hood and others, 1976, p. 12-13). Maximum potential yields to individual wells are estimated to be less than 1.000$)$ gallons per minute from alluvial aquifers along the White and Green Rivers, and less than 100 gallons per minute from alluvial aquifers in the major tributaries of Willow. Hill, Bitter, and Evacuation Creeks.

\section{Subsurface Flow to Consolidated-Rock Aquifers}

Discharge from alluvial aquifers to consolidated-rock aquifers in the southeastern Uinta Basin is estimated to be about 2.()(x) acre-feet per year. This estimate is based on simulations with ground-water models of consolidated-rock aquifers and represents the amounts of recharge from alluvial aquifers required to balance the steady-state discharge of the consolidated-rock aquifers. Discharge from alluvial aquifers to consolidated aquifers occurs in the southern part of the study area where the Douglas Creek aquifer is in contact with the alluvial aquifers and in the western part of the study area where the hird's-nest aquifer is in contact with the alluvial aquifer along Evacuation Creek. Discharge also occurs in the western part of the study area where alluvial aquifers along the White River leak water to the underlying Uinta Formation.

Table 4. Summary of evapotranspiration by phreatophytes from alluvial aquifers

\begin{tabular}{|c|c|c|c|c|}
\hline $\begin{array}{c}\text { Drainage } \\
\text { basin }\end{array}$ & $\begin{array}{l}\text { Percent } \\
\text { densitv }\end{array}$ & $\begin{array}{c}\text { Area } \\
\text { density } \\
\text { (acres) }\end{array}$ & $\begin{array}{c}\text { Estima:ed } \\
\text { evapo- } \\
\text { transpiration } \\
\text { (teet pe: vear) }\end{array}$ & $\begin{array}{c}\text { Total } \\
\text { water } \\
\text { consumed } \\
\text { (acre-feet per vear) }\end{array}$ \\
\hline \multirow[t]{3}{*}{ Bitter Creek } & 100 & 765 & 2.24 & 1,714 \\
\hline & 50 & 1.3 .36 & .34 & 454 \\
\hline & 10 & 2.158 & .05 & 108 \\
\hline Total & & 4,259 & & 2.276 \\
\hline \multirow[t]{3}{*}{ Evacuation Creek } & 100 & 147 & 2.24 & 329 \\
\hline & 50 & 531 & .34 & 181 \\
\hline & 10 & 1,124 & .05 & 56 \\
\hline Total & & 1.802 & & 566 \\
\hline \multirow[t]{3}{*}{ Hill Creek } & 100 & 1.727 & 2.24 & 3,868 \\
\hline & 50 & 1.065 & .34 & 362 \\
\hline & 10 & 4,558 & .05 & 228 \\
\hline Total & & 7,350 & : & 4.458 \\
\hline \multirow[t]{3}{*}{ Willow Creek } & 100 & 2,816 & 2.24 & 6.308 \\
\hline & 50 & 1,018 & .34 & 346 \\
\hline & 10 & 5.811 & .05 & 291 \\
\hline Total & & 9.645 & & 6.945 \\
\hline $\begin{array}{l}\text { TOTAL } \\
\text { (rounded) }\end{array}$ & & 23.100 & & 14.200 \\
\hline
\end{tabular}


Table 5. - Summary of chemical quality

\begin{tabular}{|c|c|c|c|c|c|c|}
\hline \multirow{2}{*}{ Variable } & \multicolumn{3}{|c|}{ White River alluvial aquifer } & \multicolumn{3}{|c|}{ Evacuation Creek alluvial aquifer } \\
\hline & $\begin{array}{c}\text { Number } \\
\text { ot samples }\end{array}$ & Mean & $\begin{array}{l}\text { Minimum- } \\
\text { maxımum }\end{array}$ & $\begin{array}{c}\text { Number } \\
\text { of samples }\end{array}$ & Mean & $\begin{array}{l}\text { Minimum- } \\
\text { maximum }\end{array}$ \\
\hline Water temperature (degrees Celsius) & 13 & 10.9 & $8.5-13.5$ & 12 & 11.2 & $7.5-18.0$ \\
\hline $\begin{array}{l}\text { Specific conductance (micromhos } \\
\text { per centimeter at } 25^{\circ} \mathrm{Cl}\end{array}$ & 12 & 3,422 & $2.500-4.400$ & 12 & 4.507 & $4.060-4.840$ \\
\hline $\mathrm{pH}(\log$ units $)$ & 11 & $7.7^{\prime}$ & 7.4-8.0 & 12 & $7.7^{\prime}$ & $7.4-8.2$ \\
\hline & \multicolumn{6}{|c|}{ Milligrams per liter } \\
\hline Alkalinity (as $\mathrm{CaCO}$ ) & 13 & 4.39 & $367-550$ & 12 & 450 & $320-508$ \\
\hline Hardness (as $\left.\mathrm{CaCO}_{3}\right)$ & 1.3 & 1.057 & $530-1.600$ & 12 & 1,265 & $880-1,400$ \\
\hline Calcium (as Ca) & 13 & 171 & $65-280$ & 12 & 181 & $160-210$ \\
\hline Magnesium (as Mg) & 1.3 & 154 & $90-2.30$ & 12 & 195 & 11()$-210$ \\
\hline Sodium (as $\mathrm{Na}$ ) & 1.3 & 514 & $400-610$ & 12 & 720 & $660-850$ \\
\hline Potassium (as K) & 13 & 4.2 & $2.6-5.5$ & 12 & 7.4 & $5.7-11$ \\
\hline Chloride (as $\mathrm{Cl}$. & 1.3 & 144 & $79-190$ & 12 & 52 & $4.3-59$ \\
\hline Sulfate (as $\mathrm{SO}_{4} 1$ & 1.3 & 1,466 & $8.30-2,100)$ & 12 & 2.175 & 1.80()$-2.400$ \\
\hline Fluoride (as F) & 1.3 & .7 & $0.2-1.2$ & 12 & 1.6 & $1.0-1.8$ \\
\hline Silica (as $\left.\mathrm{SiO}_{2}\right)$ & 1.3 & 17 & $15-20$ & 12 & 11 & $8.3-14$ \\
\hline Dissolved solids (calculated) & 1.3 & 2,738 & $1,76.5-3,650$ & 12 & 3,615 & $3,1.30-3,900$ \\
\hline Nitrogen, ammonia (as N) & 1 & .62 & - & - & - & - \\
\hline Nitrogen. nitrate (as $\mathrm{N}$ ) & 1 & .03 & - & - & - & - \\
\hline \multicolumn{7}{|c|}{ Micrograms per liter } \\
\hline Boron (as B) & 1.3 & 4.046 & $1.200-6.900$ & 12 & $2,6,33$ & $1.800-6.100$ \\
\hline Iron (as Fe) & 4 & 60 & 3()$-80$ & 3 & 47 & $4(0-60$ \\
\hline Manganese (as Mnı & 4 & .352 & $280-.380$ & 3 & .37 .3 & $30-580$ \\
\hline
\end{tabular}

Geometric mean

\section{Quality}

The dissolved constituents in ground water of the southeastern Uinta Basin are derived initially from rainfall and snowmelt and subsequently from the water-rock interactions that take place when rainfall. snowmelt, and streamflow recharge the aquifers. Kimball 119811 has discussed the reactions of dissolved constituents in the ground water and has described the sources of the major solutes.

\section{Chemical and Physical Characteristics}

The aspects of water quality that will be discussed for the alluvial aquifers include dissolved solids, water temperature. specific conductance, $\mathrm{pH}$, alkalinity, hardness, major constituents, and trace elements. The various terms that are used in reporting water-quality characteristics are defined in each of the annual data releases of the U.S. Geological Survey isee for example, U.S. Geological Survey, 1980, p. 5-13). Hem (1970) also defines many terms and presents a useful discussion of the interpretation of water-quality characteristics. The quality of water from the major alluvial aquifers is summarized in table 5 and shown by patterns in figure 5 .

The water quality in the alluvial aquifers not only varies downstream in each drainage, but it also varies vertically with- in the aquifers. The vertical variation generally is due to differing effects of evapotranspiration in the aquifers. At most sampling sites, two observation wells were completed in the alluviumone shallow and one deep. In general, dissolved-solids concentrations are greater in the shallow wells because they are more affected by evapotranspiration. An extreme example of this is at wells (D-12-23) $21 \mathrm{ccd}-1$ and 2 in the middle reaches of Bitter Creek. The dissolved-solids concentration in shallow well 2, ranged from 15,000 to 21.000 milligrams per liter, whereas the concentrations in deep well 1. ranged from 7.300 to 8.300 milligrams per liter. The large concentrations in the shallow well are comparable to the concentrations in well (D-10-20) 10ada-1 near the mouth of Bitter Creek.

Increases in dissolved-solids concentrations downgradient are due to the same reactions that cause vertical differences in the concentrations within the aquifer. These differences are indicated in wells (D-12-23) 21ecd-1 and (D-11-22) 26dde-1 where mean dissolved-solids concentrations increased from 7,900 milligrams per liter at well (D-12-23) 21 ced-1 to 14,400 milligrams per liter at well (D-11-22) 26dde-1 (fig. 6).

There is little variation in water temperature between the different alluvial aquifers. In general, the water temperature was about $11^{\circ} \mathrm{C}$. which is about the mean annual temperature in the lower altitudes of the southeastern Uinta Basin (Waltemeyer, 1982, pl. 2 ).

Specific conductance is a useful indicator of the dissolved- 


\begin{tabular}{|c|c|c|c|c|c|c|c|c|}
\hline \multicolumn{3}{|c|}{ Bitter Creek alluvial aquifer } & \multicolumn{3}{|c|}{$\begin{array}{l}\text { Willow and Hill Creek } \\
\text { alluvial aquifers }\end{array}$} & \multicolumn{3}{|c|}{$\begin{array}{c}\text { Other alluvial aquifers (Coyote } \\
\text { Wash, Cottonwood Wash, Hells } \\
\text { Hole Canyon, Red Wash, and } \\
\text { Southam Canyon) }\end{array}$} \\
\hline $\begin{array}{c}\text { Number } \\
\text { of samples }\end{array}$ & Mean & $\begin{array}{l}\text { Minimum- } \\
\text { maximum }\end{array}$ & $\begin{array}{l}\text { Number } \\
\text { of samples }\end{array}$ & Mean & $\begin{array}{l}\text { Minimum- } \\
\text { maximum }\end{array}$ & $\begin{array}{l}\text { Number } \\
\text { of samples }\end{array}$ & Mean & $\begin{array}{l}\text { Minimum- } \\
\text { maximum }\end{array}$ \\
\hline 29 & 10.8 & $7.0-16.5$ & 18 & 11.1 & $6.0-14.0$ & 88 & 12.0 & $6.0-32.0$ \\
\hline 29 & 10.200 & $1.700-21.000$ & 18 & 5,963 & $940-10,250$ & 89 & 2,836 & $680-7.250$ \\
\hline 28 & $7.7^{1}$ & $7.2-8.1$ & 18 & $7.9^{1}$ & $7.2-8.3$ & 70 & 18.2 & $7.3-10.0$ \\
\hline \multicolumn{9}{|c|}{ Milligrams per liter } \\
\hline 29 & 617 & $239-1,390$ & 19 & 884 & $390-1,070$ & 78 & 444 & $43-1,530$ \\
\hline 29 & 3.934 & $1,700-12.000$ & 19 & 1,152 & $410-2,000$ & 78 & 790 & $21-3,500$ \\
\hline 29 & 319 & $150-550$ & 19 & 93 & $60-140$ & 78 & 164 & $5-790$ \\
\hline 29 & 765 & $260-2,700$ & 19 & 223 & $57-420$ & 78 & 91 & $0.2-390$ \\
\hline 29 & 1,980 & $300-4.700$ & 19 & 1,160 & $81-2.100$ & 78 & 513 & $73-930$ \\
\hline 29 & 22 & $4.1-76$ & 19 & 6.8 & $2.5-17.0$ & 78 & 5.7 & $1.1-25$ \\
\hline 29 & 189 & $27-950$ & 19 & 108 & $11-220$ & 78 & 85 & $9.6-280$ \\
\hline 29 & 6.986 & $1.900-19.000$ & 19 & 2.585 & $180-5.200$ & 78 & 1.294 & $51-4.400$ \\
\hline 29 & 1.0 & $0.4-4.3$ & 19 & 2.1 & $0.6-6.1$ & 78 & 1.7 & $0.2-6.9$ \\
\hline 29 & 11 & 4-19 & 19 & 15 & $6.7-24$ & 78 & 12 & $0.7-21$ \\
\hline 29 & 10,645 & $3,056-27,795$ & 19 & 4,730 & $660-8,654$ & 78 & 2,408 & $435-6,672$ \\
\hline- & - & - & - & - & - & 24 & .22 & $0.01-1.8$ \\
\hline - & - & - & - & - & - & 24 & 2.08 & $0.0-9.3$ \\
\hline \multicolumn{9}{|c|}{ Micrograms per liter } \\
\hline 29 & $6,06.3$ & $390-17,000$ & 19 & 9.156 & $370-21,000$ & 81 & 1.052 & $30-3.700$ \\
\hline 16 & 1.151 & $0.0-9,900$ & 6 & 73 & $40-110$ & 47 & 95 & $0.0-540$ \\
\hline 17 & 912 & $90-5.800$ & 6 & 92 & $30-180$ & 44 & 305 & $0.0-2.500$ \\
\hline
\end{tabular}

solids concentration of natural waters because changes in ion concentrations result in changes in specific conductance. The ratio of dissolved solids to specific conductance in the water in the alluvial aquifers ranged from about 0.8 to 1.3 . The ratio was greatest in waters with the greatest sulfate concentrations, such as in the alluvial aquifer in Bitter Creek. For the alluvial aquifers in the remainder of the area. the ratio was about 0.8 .

Although the values of $\mathrm{pH}$ ranged from 7.2 to 10.0 , there was only a small amount of variation from the mean of 7.9 . The largest values of $\mathrm{pH}$ were found in the alluvial aquifer in Hells Hole Canyon at well (D-10-25) 8aca-2. The smallest values were in the White River alluvial aquifer, at well (D-10-2.3) $23 \mathrm{dbd}-3$. and in the upper reaches of the Hill Creek alluvial aquifer at well (D-13-19) 13aad-2. The small amount of variation indicates that $\mathrm{pH}$ is well buffered. This buffering is discussed later in the section describing the mass-transfer model for the Bitter Creek alluvial aquifer.

Alkalinity is the acid-neutralizing capacity of a natural water (Stumm and Morgan, 1981, p. 185-186). In the southeastern Uinta Basin, this mostly is due to bicarbonate. However, in some of the aquifers there is a small contribution from borate species. Alkalinity usually is reported as an equivalent amount of calcium carbonate $\left(\mathrm{CaCO}_{3}\right)$, as in table 5. This is numerically equal to about 82 percent of the bicarbonate concentration and can be converted to milliequivalents by dividing by 50 , the equivalent weight of $\mathrm{CaCO}_{3}$.
Alkalinity increases downstream in each of the alluvial aquifers. except for the aquifer in Evacuation Creek. The mean alkalinity in the upper reaches of Willow Creek at well (D-13-21) 15adc-1 was 660 milligrams per liter, and near the mouth of Willow Creek, at well (D-10-20) 15dcb-1, the mean alkalinity was 1,020 milligrams per liter. Although the increase was large. it was not as large as the increase in other constituents in the same reach. This is because alkalinity is controlled by the precipitation of calcite (see mass-transfer model). In the alluvial aquifer in Bitter Creek, the alkalinity increased from 4.30 to 891 milligrams per liter. Again, the increase was not as large as for other solutes. By contrast, the alluvial aquifer in Evacuation Creek showed no large increase in alkalinity.

Hardness is due to divalent cations in natural waters, generally calcium and magnesium. The units for reporting hardness are milligrams per liter as $\mathrm{CaCO}_{3}$; thus, hardness may be compared with alkalinity. If the hardness is greater than alkalinity. the difference is termed the noncarbonate hardness.

The alluvial aquifers in Red Wash, Coyote Wash, Hells Hole Canyon, and Cottonwood Wash contain soft or moderately hard water (see classification by Hem, 1970, p. 225). The remainder of the aquifers contain water that is very hard. Most of the hardness is noncarbonate hardness. This is from the fractionation of solutes during evaporative concentration. Both calcium and the carbonate species (bicarbonate and carbonate) 


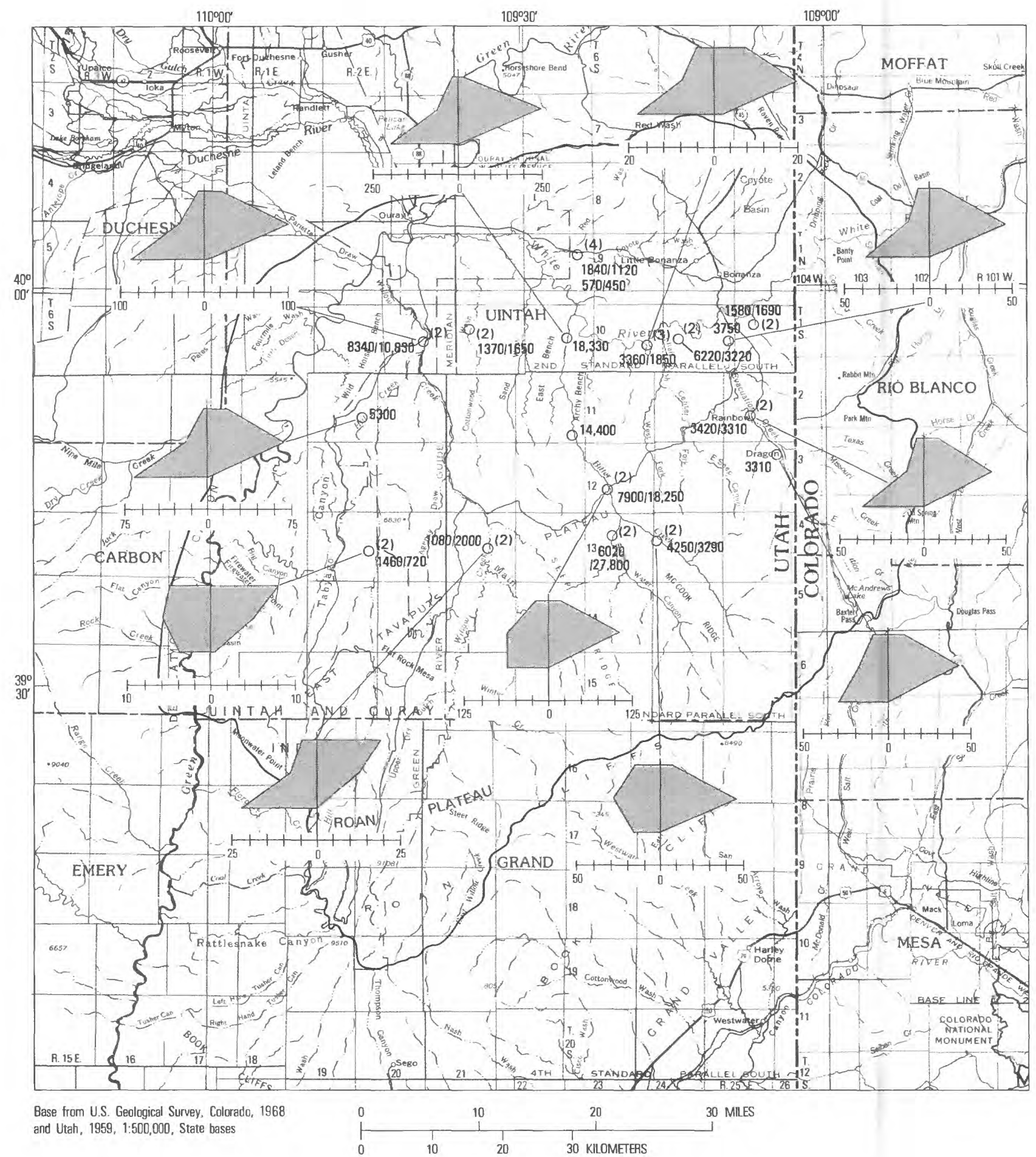

\section{EXPLANATION}

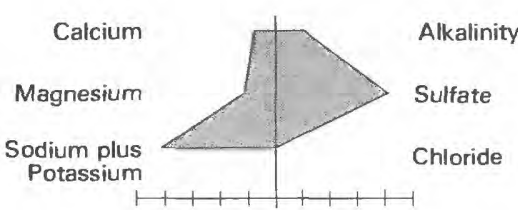

MILIEQUIVALENTS PER LITER

(scale varies)

$3750^{\circ}$ WELL - Numbers by well symbol indicate mean dissolved-solids concentration in milligrams per liter. Number in parentheses indicates number of wells at site. When two numbers are by well symbol, first number indicates mean dissolved-solids concentration for well 1 at site, and second number indicates value for well 2 at site

BOUNDARY OF STUDY AREA 
are controlled by precipitation of calcite during evaporative concentration. but magnesium is not controlled to the same extent. As a result the large increase in magnesium concentrations with respect to alkalinity results in a large amount of noncarbonate hardness.

In the upper reaches of the alluvial aquifers, the hardness was about $5(0)$ milligrams per liter, but hardness increases downstream as the solutes are concentrated by evaporation. The alluvial aquifer of Bitter Creek is affected the most. At the mouth of Bitter Creek, at well (D-10-22) 10ada-1. the mean hardness was 3.780 milligrams per liter.

The concentrations of other major constituents in water from the alluvial aquifers (sodium, potassiun, chloride, sulfate. fluoride. and silical show both similarities and differences to the behavior of calcium. magnesium. and the carbonate species. The changing patterns in figure 5 show that sodium increases similarly to magnesium. but that sodium becones the major cation in the alluvial aquifers near the mouth of each drainage. The mean sodium concentration at the mouth of Bitter Creek, at well (D-20)-22) 10ada-1. was 4.580 milligrams per liter. Near the mouth of Willow Creek, at well (D-10-20) 15dch-1, the mean sodium concentration was 2.033 milligrams per liter. Sodium is concentrated by evapotranspiration. but it also is added to the water in the alluvial aquifers by recharge of water from bedroch ayuifers (fig. 24). The changes in sodium concentration are discussed in the mass-transfer model for the alluvial aquifer of Bitter Creek.

Potassium concentrations remain relatively small in all the alluvial aquifers. Evapotranspiration concentrates potassium. but its concentrations never increased to much more than 20 milligrams per liter. except in the alluvial aquifer of Bitter Creek. The concentration of potassium. like calcium. is controlled by water-rock interactions. However, the control on potassium concentration is not by the precipitation of a mineral phase. The control is from the sorption of potassium onto clay minerals which are present in the alluvium. The alluvium contains abundant illite and smectite clays. Boles and Franks (1979) suggest that potassium is involved in the conversion of smectite to illite during diagenesis of Gulf Coast sediments. Even though the diagenetic reaction does not occur in the alluvial aquifers, the two clays have the capacity to adsorb the potassium and limit its concentration in solution.

Concentrations of chloride show a large range of variation in the alluvial aquifers, increasing from 9.6 to 950 () milligrams per liter. As the water in the aquifers is concentrated by evapotranspiration. chloride is conserved and the concentration increases. Chloride never becomes a dominant anion because sulfate increases proportionally to chloride and always is more concentrated.

The concentrations of sulfate and carbonate species are nearly equal in the spring waters that recharge the alluvial aquifers in the upstream reaches of the drainage. During the course of evaporative concentration. however, sulfate increases greatly, while the concentrations of carbonate species are controlled. Thus. sulfate becomes the dominant anion in each of the alluvial aquifers, as shown by the patterns in figure 5 .
Near the mouth of Willow Creek. the sulfate concentration at well (D-10-20) 15dcb-1 has a mean of 4,950 milligrams per liter. In Bitter Creek at well (D-10-22) 10ada-1, the mean sulfate concentration is 12.000 milligrams per liter. Other alluvial ayuifers do not show such extreme values. At well (D-10-23) 2.3dhd-1 in the White River alluvial aquifer, the mean sulfate concentration is 1.850 milligrams per liter. In the alluvial aquifer in Evacuation Creek, the mean concentration at well (D-11-25) 7 dac-2 is 2.570 milligrams per liter.

Nutrients and trace elements were not determined for many of the samples from the alluvial aquifers. Boron was determined in most samples. and iron and manganese were determined occasionally (table 5). Boron concentrations were large in comparison to most natural waters. The greatest concentrations were in water from the Willow and Bitter Creek alluvial aquifers. where mean concentrations exceeded the boron concentration of sea water (Hem, 1970. p. 187). Boron apparently is a constituent of the deposits of the ancient Lake Uinta. Other lake deposits. notably in the closed-basin deposits of southeastern California, contain considerable concentrations of boron (Hardie. 19681 . Ground water acquires boron from contact with the deposits of the ancient lakes, and the concentrations subsequently are enhanced by evaporative concentration of the solutes. There is no solubility control on the concentration of boron within the concentration ranges observed in the study area.

No consistent patterns for nitrogen. iron. and manganese were observed in the alluvial aquifers. The mean concentrations ranged from about 50 to about 900 micrograms per liter for both iron and manganese and from about 0.2 to about 0.6 milligram per liter as $\mathrm{N}$ for the nitrogen species.

In general, water from the alluvial aquifers is not suitable for irrigation or municipal use. The patterns of changing water quality are used to model the chemical quality in the masstransfer model described below.

\section{Mass-Transfer Model}

The changes in chemical composition of the ground water in the three aquifers in the southeastern Uinta Basin can be attributed to several physiochemical processes, including mineral precipitation and dissolution. oxidation and reduction. mixing, ion exchange, and evaporative concentration. A masstransfer model was used to help explain how these processes affect the water quality in each of the three aquifers. The PHREEQE model developed by Parkhurst. Thorstenson, and Plummer (19\$()) was used.

The changes in chemical character of water in the alluvial aquifers show many similarities to the early stages of brine formation. Evaporative concentration and the formation of brines have been summarized by Eugster and Jones (1979). They present several examples of how mineral precipitation. selective dissolution of efflorescent crusts. sorption on active surfaces, and oxidation-reduction reactions can account for

Figure 5(facing page). Variation in mean dissolved-solids concentrations and chemical character of water in the alluvial aquifers. 
the changes in water chemistry during evaporation. These reactions were used in a mass-transfer model of the Bitter Creek alluvial aquifer.

The effect of evapotranspiration on individual constituents varies: some constituents are affected while others are not affected and are concentrated in solution. Chloride usually is a conservative element during evaporation, and the increase in chloride concentration can be used to determine a concentration factor. Several authors have used chloride in this way (Eugster, 1970; Jones, 1966; Smith and Drever. 1976; Eugster and Hardie, 19781. The chemical changes that occur in the alluvial aquifers along Bitter Creek can be followed by obser ing the behavior of individual constituents with respect to chloride. In the mass-transfer model of the Bitter Creek alluvial aquifer, only the mean concentrations of individual constituents in water from the deeper wells were used to show changes in water quality $(\mathrm{p} .48$. These changes are illustrated in figures $6-10$ and summarized in table 6 .

The variation of sodium with chloride as water moves through the alluvial aquifers along Bitter Creek is shown in figure 6 . The point to the lower left represents the composition of snowmelt in the recharge area. The line of $45^{\circ}$ (unit slope) from this point represents the path of evaporative concentration. Any point plotting on the line would represent the concentration if only evaporation were responsible for changes in the water chemistry. If a point plots above the $45^{\circ}$ line. sodium has been added; and if it plots below, sodium has been removed. After shallow ground-water circulation. only a small amount of sodium has been gained from rock weathering (Kimball. 1981): but by the time water discharges at spring (D-15-25)13bad-S1. it has gained substantial sodium.

The water from spring (D-15-25)1.3bad-S1 is typical of water that recharges the alluvial aquifer. The water is then subject to evaporation, mostly in the capillary fringe, due to the extensive use of water by phreatophytes. The upper $45^{\circ}$ line in figure 6 shows the path of evaporative concentration in the alluvial aquifer.

The pattern of sodium shown in figure 6 is nearly conservative. but it does show a slight decrease with respect to chloride at well (D-13-24)18bbb-1 and a slight increase at well (D-12-23)21 ced-1 and (D-10-22)10ada-1. Such slight increases and decreases have been attributed to the cyclic wetting and drying that occurs in arid environments. Drever and Smith (1978) simulated this wetting and drying in laboratory experiments. They found that those solutes that form the most soluble precipitates when soils are completely dried, for example, sodium. chloride, sulfate, and potassium, redissolve quickly whereas calcium, magnesium, bicarbonate, and silica redissolve slowly. Even though sodium redissolves quickly, over a long period of time, some sodium is lost to mineral precipitation.

Efflorescent crusts along streambeds in the alluvium were collected and analyzed by X-ray diffraction. The minerals present included calcite $\left(\mathrm{CaCO}_{3}\right)$, dolomite $\left.\mid \mathrm{CaMg}_{4} \mathrm{CO}_{2}\right)_{2} \mid$, quartz $\left(\mathrm{SiO}_{2}\right)$, burkeite $\left(\mathrm{Na}_{2} \mathrm{CO}, \bullet 2 \mathrm{Na}_{2} \mathrm{SO}_{4}\right)$, thenardite $\left(\mathrm{Na}_{2} \mathrm{SO}_{4}\right)$. mirabilite $\left(\mathrm{Na}_{2} \mathrm{SO}_{4} \cdot 10 \mathrm{H}_{2} \mathrm{O}\right)$, nahcolite $\left(\mathrm{NaHCO}_{3}\right)$. trona $\left(\mathrm{NaHCO}_{3} \bullet \mathrm{Na}_{2} \mathrm{CO}_{2} \bullet 2 \mathrm{H}_{2} \mathrm{O}\right)$, a trace of halite $(\mathrm{NaCl})$, and some smectite (14A. expandable) clay. These minerals represent the final stages of desiccation in the alluvium. The sodium sulfate

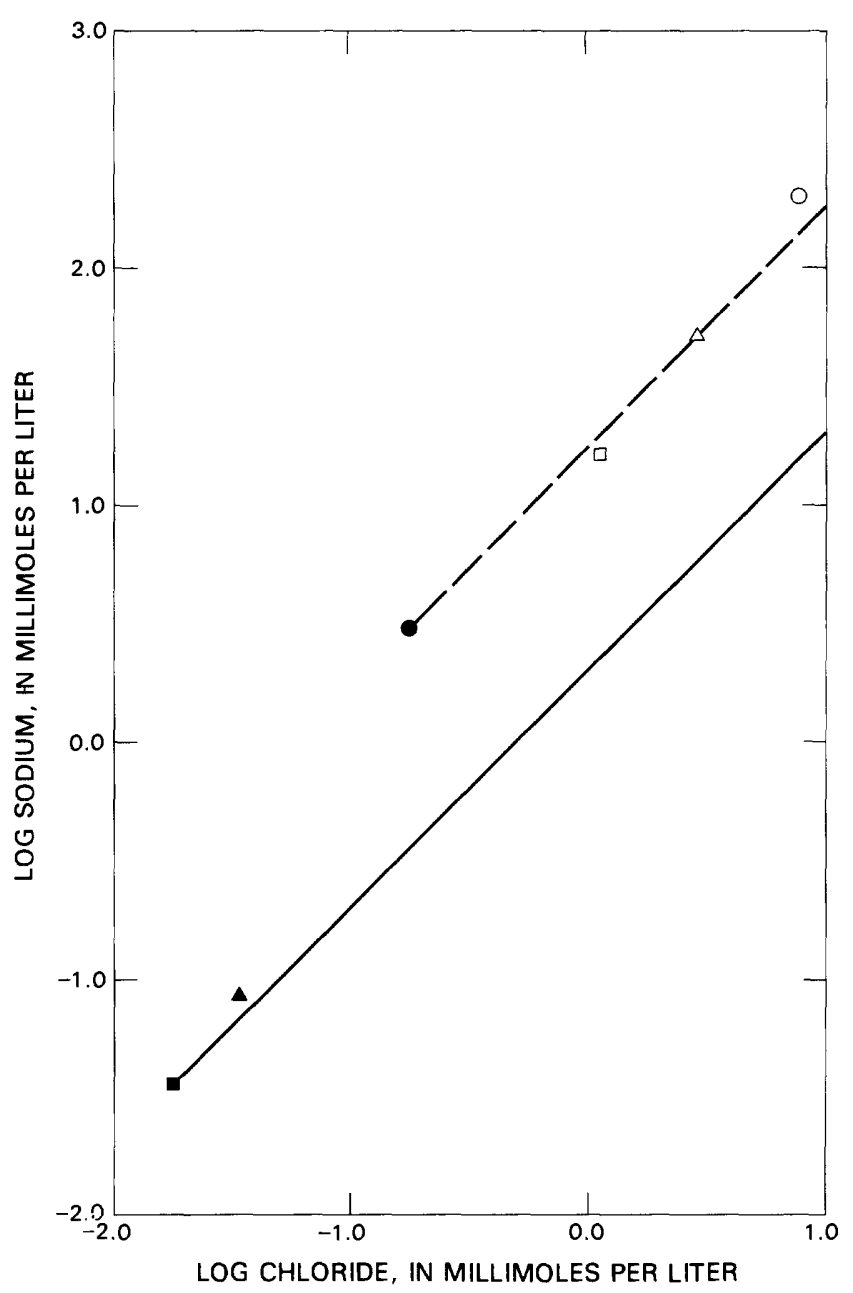

EXPLANATION

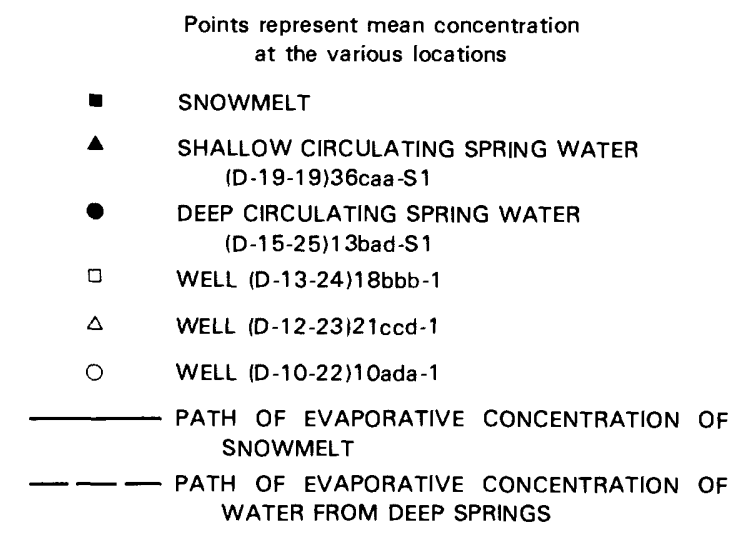

Figure 6. Variation of sodium with chloride in water from the Bitter Creek alluvial aquifer

and the sodium bicarhonate minerals dissolved quickly when wetted and return to the ground water. whereas the calcite. dolomite. and silica return solutes much more slowly.

The effect of cyclic wetting and drying can be evaluated by using an ideal sodium sulfate mineral to represent the precipitation process. Although not necessarily the major 
mineral responsible for sodium and sulfate loss. thenardite would be representative of the process. and the effect of cyclic wetting and drying can be represented as:

$$
2 \mathrm{Na}^{+}+\mathrm{SO}_{4}^{2} \rightleftharpoons \mathrm{Na}_{2} \mathrm{SO}_{4}
$$

Although sodium decreases in relation to the path of evaporative concentration during the early stages of evapotranspiration from spring (D-15-25) 1.3bad-S1 to well (D-1.3-24) $1 \times b$ bb-1, it increases from that point down the drainage. It is unlikely that the increase comes from ion-exchange reactions in the alluvium because ion exchange primarily would he the exchange of calcium and magnesium on the clays for sodium in solution 1Drever, 1482. p. 8.3-8t). The saline water also is unreactive with feldspar minerals in the alluvium. so the weathering of plagioclase to produce solium also is unlikely. Ruling out these water-rock interactions. the increase in sodium is most likel due to upuard leakage of sodium sulfate water from the hird's-nest aquifer. The flow model of the hird'snest aquifer indicates that there mal he discharge from the hirl's-nest aquifer through the L'inta Formation to discharge to the allusium in the downstream reaches of Bitter Creek.

A second type of solute behavior is shown in figures 7 and $\delta$ where calcium and alkalinity tincludes hicarbonate and carbonate ions/ are plotted against chloride. In both figures. a dashed line of unit slope is drawn using the water composition at spring (D-15-25) $1.3 \mathrm{had}-\mathrm{S} 1$ to represent evaporative concentration once the water enters the allurium. The data in each figure how a large deviation from this unit slope.

Both calcium and alkalinity show large increases from the dissolution of calcite from a snowmelt sample to spring (D-15-251 1.3had-S1 1 Kimball. 1481.p. 12). After this point the water is supersaturated with respect to calcite $1 \mathrm{CaCO}$ : which begins to precipitate by the reaction:

$$
\mathrm{Ca}^{2+}+2 \mathrm{HCO}^{-} \rightleftharpoons \mathrm{CaCO} \downarrow+\mathrm{CO}_{2}+\mathrm{H}_{2} \mathrm{O}
$$

Eugster and Jones 11979. p. 611-6131 have shown that when calcium carbonate hegins to precipitate the water chemistry may follow one of two different "paths." In the water at spring (D-15-25) 1.3had- $\$ 1$. alkalinity is greater than the milliequivalents of calcium. This results in the loss of calcium and the gain of alkalinity during evaporation.

After the precipitation of calcium carbonate begins. dolomite becomes supersaturated and may begin to precipitate by the orerall reaction:

$$
\mathrm{Mg}^{2+}+\mathrm{HCO}_{2}+\mathrm{CaCO}_{2}=\mathrm{CaMlg}_{\mathrm{CO}} \mathrm{l}_{2} \downarrow+\mathrm{CO}_{2}+\mathrm{H}_{2} \mathrm{O}
$$

This reaction also causes a chenical divide. and the water can hecome depleted in magnesium or alkalinity. depending on the ratio of milliequivalents of magnesium to alkalinity. For this water. magnesium milliequivalents are greater than the milliequivalents of alkalinity when calcium magnesium carhonate precipitation hegins: magnesium is increased and alkalinit! decreases. How magnesium follows the path of evaporative concentration during the segment from spring (D-15-25, 1.3bad-S1 to well (D-1.3-24) 18bhb-1 is shown in figure ().

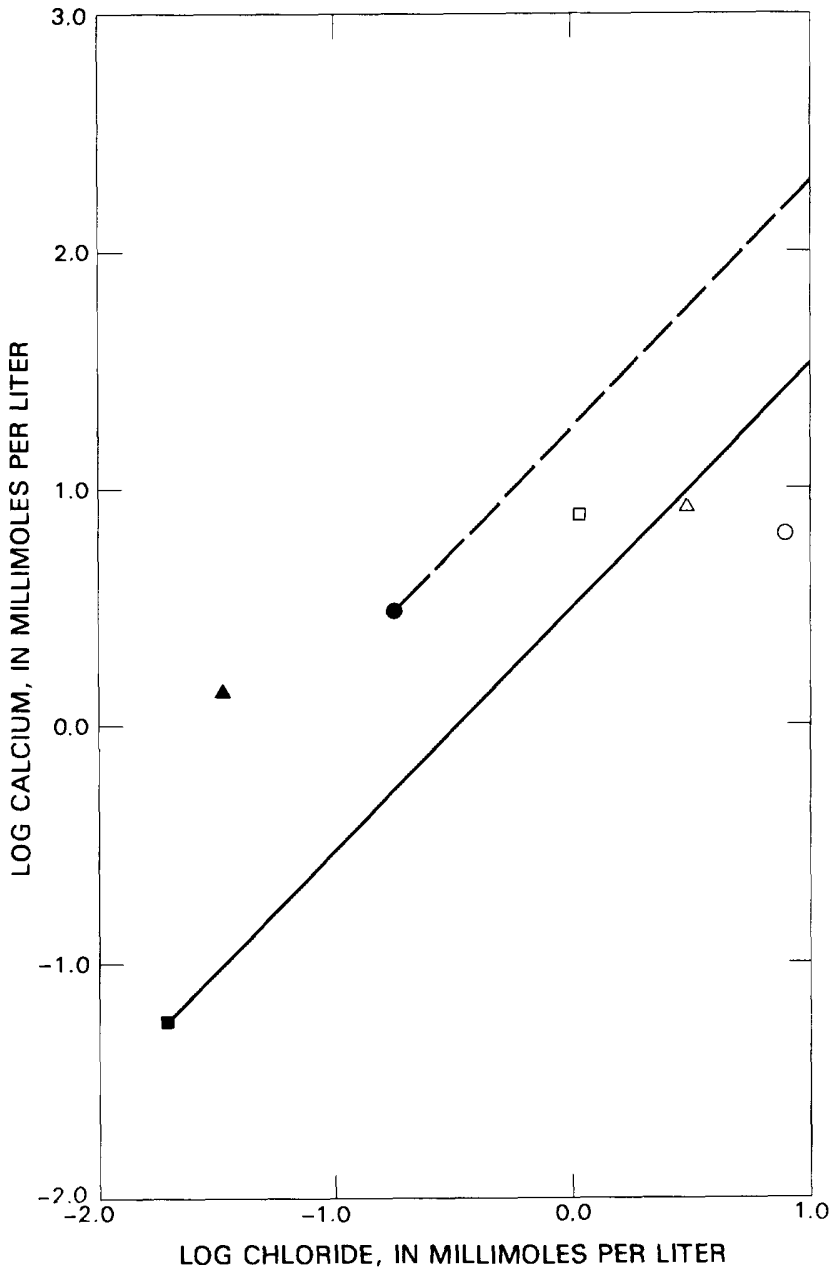

EXPLANATION

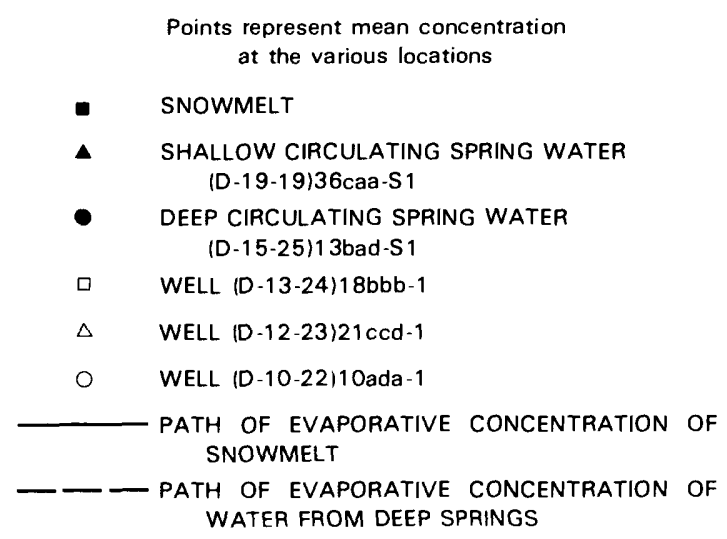

Figure 7. Variation of calcium with chloride in water from the Bitter Creek alluvial aquifer.

In some elaporative settings. the loss of magnesium could he due to the precipitation of a magnesium silicate such as sepiolite.

$2 \mathrm{Mg}_{2}+4 \mathrm{HCO}+6 \mathrm{H}_{4} \mathrm{SiO}_{4} \rightleftharpoons \mathrm{Mg}_{2} \mathrm{Si}_{4} \mathrm{O}_{2}(\mathrm{OH})_{+} \downarrow+4 \mathrm{CO}_{4}+12 \mathrm{H}_{2} \mathrm{O}_{1}$ (xa) 


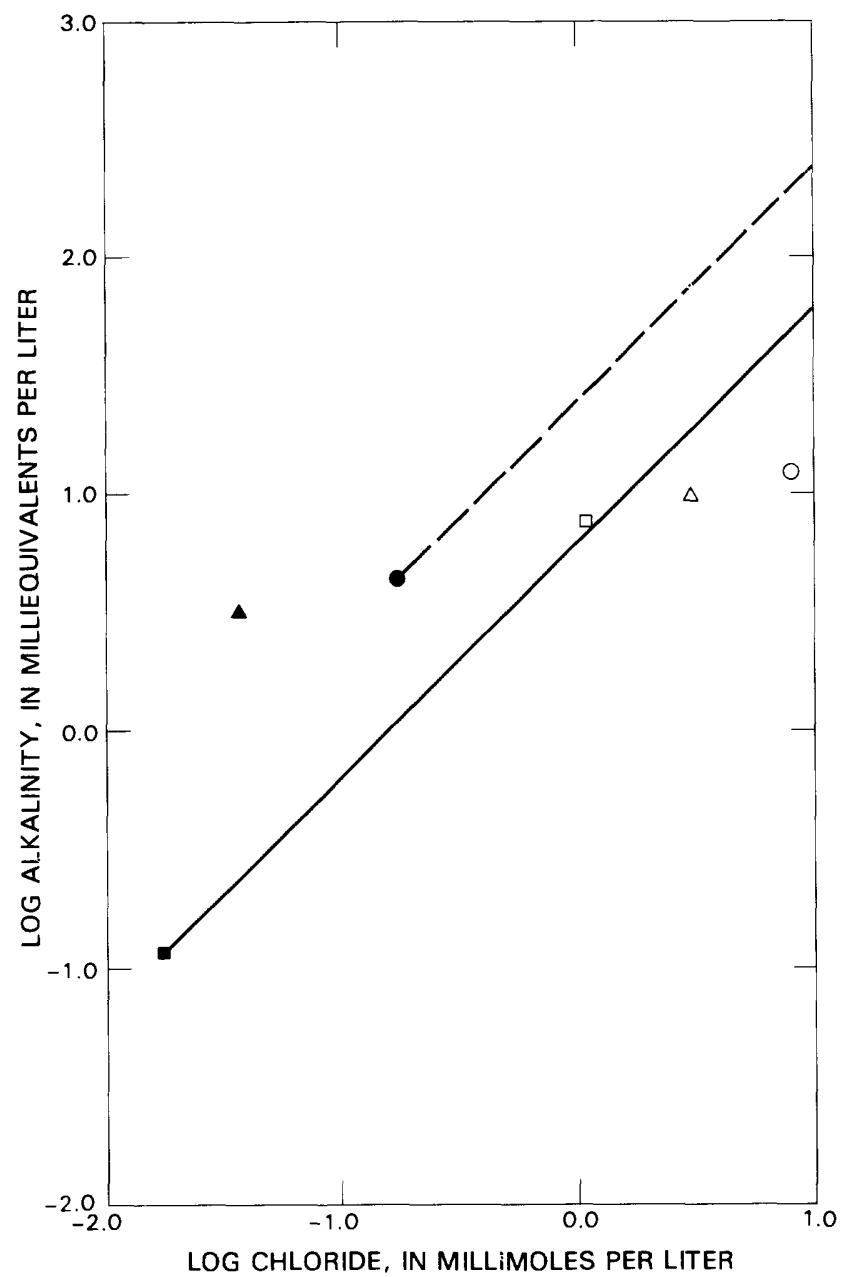

EXPLANATION

Points represent mean concentration

at the various locations

\begin{tabular}{cl}
$-\quad$ SNOWMELT \\
SHALLOW CIRCULATING SPRING WATER \\
(D-19-19)36caa-S1 \\
DEEP CIRCULATING SPRING WATER \\
(D-15-25)13bad-S1 \\
WELL (D-13-24)18isbb-i \\
$\Delta \quad$ WELL (D-12-23)21ccd-1 \\
WELL (D-10-22)10ada-1 \\
\hline- \\
- PATH OF EVAPORATIVE CONCENTRATION OF \\
SNOWMELT \\
PATH OF EVAPORATIVE CONCENTRATION OF \\
WATER FROM DEEP SPRINGS
\end{tabular}

Figt:re 8. Variation of alkalinity with chloride in water from the Bitter Creek alluvial aquiter. Alkalinity is approximately equal to bicarbonate in the $\mathrm{pH}$ range of these waters.

This reaction results in the same chemical divide as the precipitation of dolomite, with the additional loss of silica. Magnesium loss also could be from the incorporation of magnesium into clas minerals (J. I. Drever. University of Wyoming. written commun.. 19811. The abundance of dolomite in samples of the

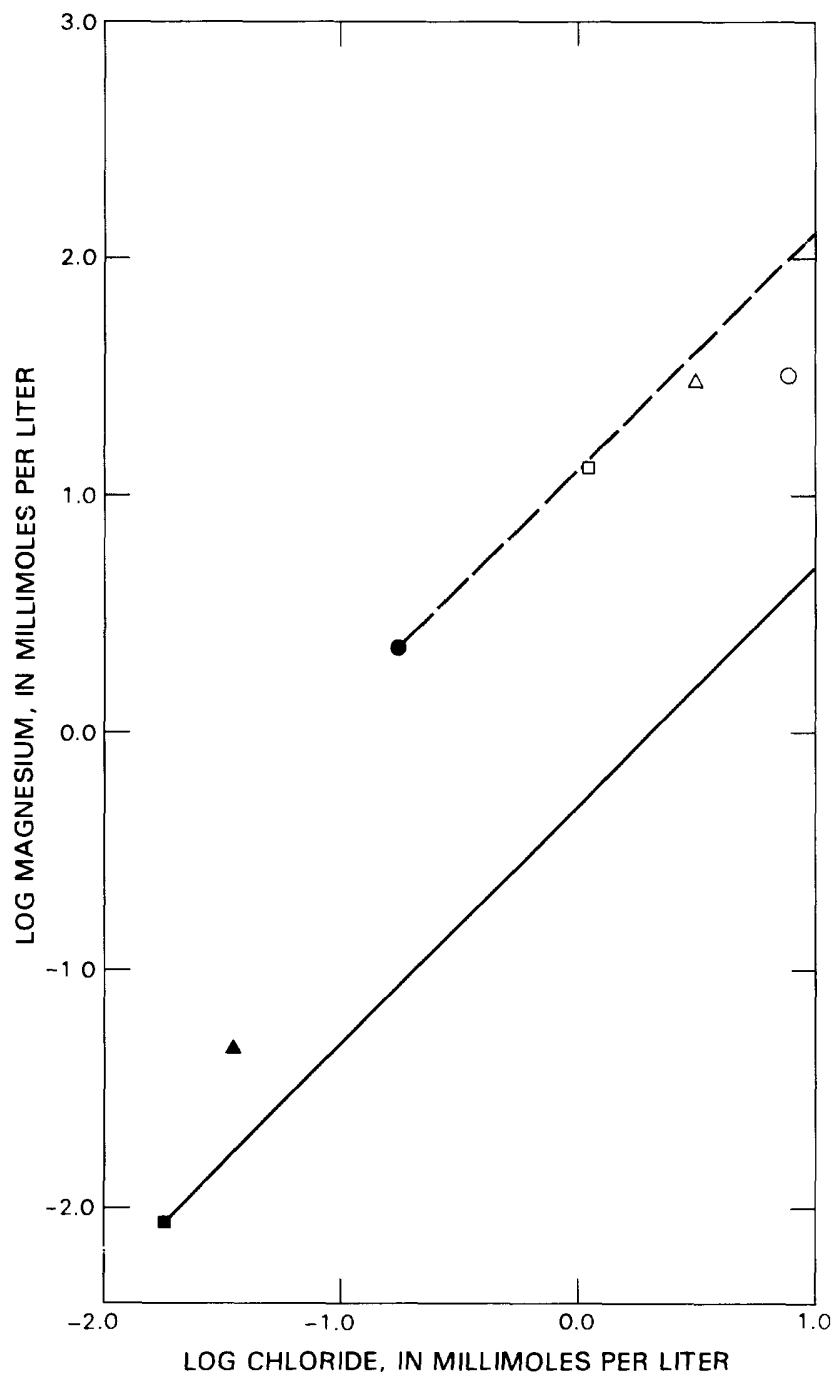

\section{EXPLANATION}

Points represent mean concentration at the various locations

SNOWMELT
SHALLOW CIRCULATING SPRING WATER
(D-19-19)36caa-S 1
DEEP CIRCULATING SPRING WATER
(D-15-25)13bad-S 1
WELL (D-13-24)18bbb-1
$\Delta \quad$ WELL (D-12-23/21ccd-1
WELL ID-10-22)10ada-1
PATH OF EVAPORATIVE CONCENTRATION OF
SNOWMELT
PATH OF EVAPORATIVE CONCENTRATION OF
WATER FROM DEEP SPRINGS

Figure 9. Variation of magnesium with chloride in water from the Bitter Creek alluvial aquifer.

alluvium indicates that reaction $x$ could account for most of the loss of magnesium. but it was not determined if this dolomite was authigenic or detrital. 
The large concentrations of calcium in water from the alluvial aquifer might indicate that mineral precipitation does not control its concentration. However. as the salinity increases down gradient, the effects of ionic strength and ion pairing hecome important. This situation allows the molality of total calcium to be large, while the activity of calcium ions remains small. For example. at well (D-10-22) 10ada-1, the mean concentration of calcium is 254 milligrams per liter. The activity coefficient for the calcium ion $\left(\mathrm{Ca}^{2+}\right)$ is calculated by PHREEQE to be 0.29. Thus. the activity of the free calcium ion is only 35 milligrams per liter, with a concentration of calcium ion of 121 milligrams per liter. The remaining 1.33 milligrams per liter of total calium in the $u$ ater is present in the various calcium compleses, prinicipally $\mathrm{CaSO} 9$ and $\mathrm{CaHCO}^{+}$.

The pattern of sulfate is similar to sodium and is shown in figure 10. Sulfate increases less rapidly than calcium or alkalinity during shallow ground-water circulation. but after deeper circulation it is added substantially by the oxidation of pyrite (Kimball. 1981. p. 12). Once in the alluvium and subject to evapotranspiration, it decreases below the path of evaporative concentrations because of the effects of cyclic wetting and drying represented by reaction 1. Although sulfate does not increase ahove the line of evaporative concentration in the downstream reaches of Bitter Creek. the increases in milliequivalents of sodium and sulfate from well (D-12-23) $21 \mathrm{ccd}-1$ to well $(\mathrm{D}-10-22) 10 \mathrm{ada}-1$ are equal, approximately 70 milliequivalents for each. This again indicates the recharge of a sodium sulfate water to the alluvial aquifers, probably through the Uinta Formation from the hird's-nest aquifer.

The concentrations of potassium and silica do not show the same type of variation as do the other major solutes. These two solutes are controlled by sorption reactions with the clay minerals in the alluvium. The major clay minerals in the alluvium. as determined by X-ray diffraction. are illite and smectite. Potassium could be involved in sorption on the illite. whereas silica could be controlled by both clays. Siever and Woodford (197.3) have shown how silica concentrations can be controlled by various clay minerals. The consistent concentrations of silica in the alluvial aquifer indicate such a control. The formation of new clay minerals involving the consumption of silica is unlikely. Illite and smectite generally would be "stable" clays at the salinities in the alluvium. Analcime $\left(\mathrm{NaAlSi}_{3} \mathrm{O}_{n} \bullet \mathrm{H}_{2} \mathrm{O}\right)$ is present in the alluvial sediments as a detrital product of weathering from the Green River Formation; not as a reaction product from the clays in the alluvium.

An evaporative budget for chemical changes in water from the Bitter Creek alluvial aquifer is given in table 5 . The changes that occur from rainfall and snowmelt are shown, and the concentration factors in terms on chloride increase at each set of points are given in figures $6-10$. The actual loss of the constituents is somewhat masked by the logarithmic scales in these figures. The amount of each constituent that is lost or gained in each segment of the reaction is given in table 6 . This percentage of loss for each constituent accounts for the losses or gains only after the constituents have entered the alluvial aquifer. Note that calcium and alkalinity decrease early. Each of the solutes increase before entering ihe alluvium through the various processes that have been described above and by Kimball (1981).

The $\mathrm{pH}$ increased between wells (D-1.3-24) 18bbb-1 and

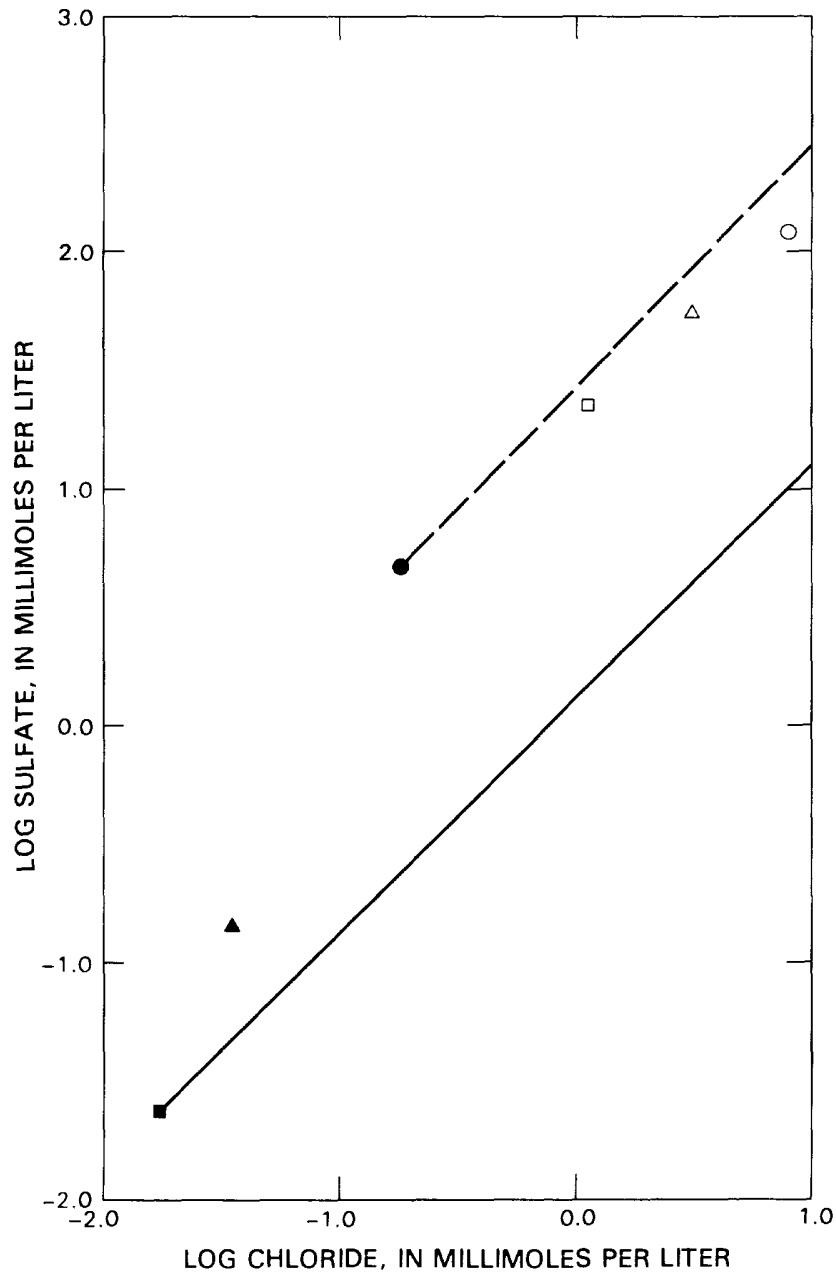

EXPLANATION

Points represent mean concentration at the various locations

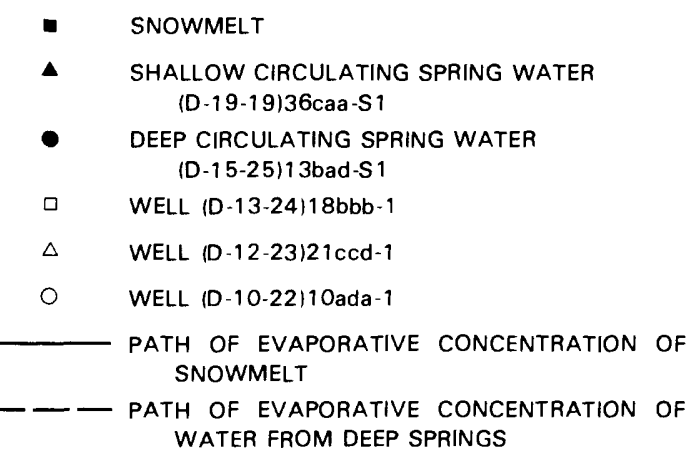

Figure 10. Variation of sultate with chloride in water from the Bitter Creek alluvial aquifer.

(D-12-23) 21ccd-1. After this increase, the $\mathrm{pH}$ remained constant downgradient to the next well. (D-10-22) 10ada-1. Thorstenson. Fisher, and Croft 11979 , p. 1491 ) have shown how the combination of carbonate-equilibria and ion-exchange reactions can buffer the $\mathrm{pH}$ of a ground water. and it is possible that a similar $\mathrm{pH}$ buffer is operative in the alluvial aquifers. 


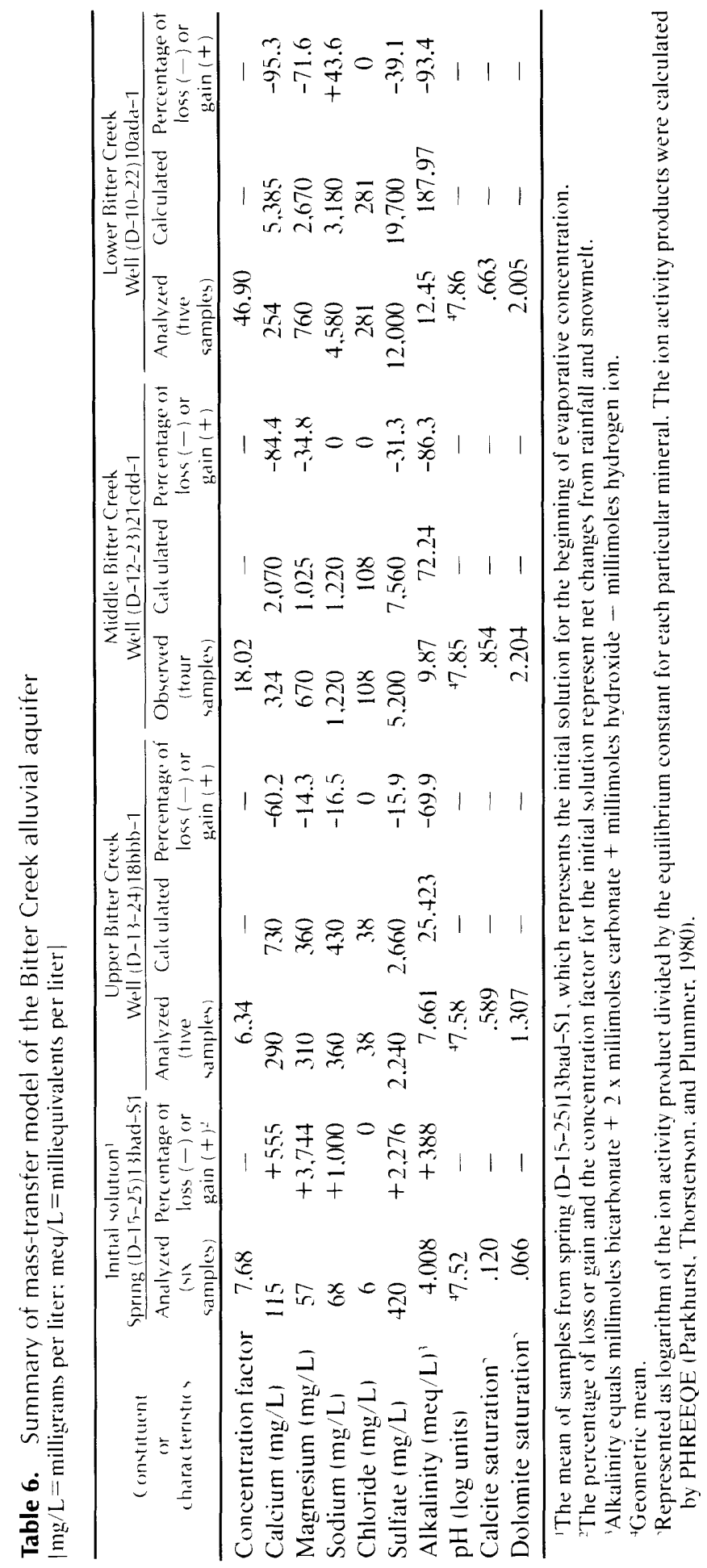




\section{Bird's-Nest Aquifer}

The bird's-nest aquifer is in the Parachute Creek Member of the Green River Formation and has been identified in test holes near Federal Lease tracts $\mathrm{Ua}$ and $\mathrm{Ub}$ and along Evacuation Creek and the White River where the aquifer crops out at the surface IVTN. Colorado. Inc., 1977. p. II-1201. The term "hird's-nest aquifer" corresponds to the term "bird'snest zone" described by Cashion (1967, p. 17). because the outcrop of his informally named zone has the appearance of a wall supporting many swallows' nests. For the purpose of this report the zone is called bird's-nest aquifer. The aquifer's areal extent to the west and north is unknown, but it has been estimated to extend as far as Bitter Creek to the west and several miles beyond the White River to the north (VTN, Colorado. Inc.. 1977. fig. 11-72). The thickness of the aquifer ranges from 90 to 205 feet and averages about 115 feet near tracts Ua and Ub (VTN. Colorado, Inc., 1977. p. II-121).

The aquifer contains solution cavities as much as 2 feet in diameter. which were created by the removal of readily soluble nahoolite ( $\mathrm{NaHCO}_{2}$ ). Where the brittle beds surrounding the cavities have been fractured or jointed, and the cavities connected, a permeable zone has been formed. The fracturing or jointing of the rocks may be related to the occurrence of gilsonite veins because the primary set of joints in the vicinity of tracts Ua and Ub trend north $62^{\circ}$ west with near vertical dip IVTN, Colorado, Inc. 1977. p. V-40), and the gilsonite veins have an average strike of about north $60^{\circ}$ west and also have nearly vertical dips (Cashion, 1967. p. 31).

The transmissivity of the aquifer is variable. Analyses of aquifer tests by personnel of the White River Shale Project indicate a range in transmissivity from about 1 to 15.000 feet squared per day and a range in storage coefficient from about $1 \times 10^{-1}$ to $7 \times 10^{-1}$ (VTN. Colorado. Inc.. 1977, table II-1.3). Maximum yields to individual wells, based on model simulations, are estimated to be 5.000 gallons per minute, with a maximum drawdown of ahout 200 feet after 30 days of pumping.

The range in transmissivity is thought to be related to the amount of fracturing and solution. In areas where fracturing and solution have not taken place, transmissivities are near zero. Well (D-9-21) 26aa-1, drilled in to the bird's-nest aquifer, penetrated nahcolite-filled cavities: and the well produced only a small amount of water. Well $(\mathrm{D}-10-21) 2 \mathrm{cb}-1$. about 3 miles to the south, produced 600 gallons per minute from the bird'snest aquifer during air-rotary drilling (James Moyer. TOSCO Corp., oral commun., February 16. 1978).

The largest storage coefficient was obtained from an aquifer test at well (D-10-24) 26ccd-2 on the southern edge of tracts $\mathrm{U} a$ and $\mathrm{Ub}$ where the aquifer is unconfined. The smallest value was obtained from an aquifer test at well (D-10-24) 20aad-2 on the northern edge of tracts Ua and Ub where the aquifer is confined (VTN. Colorado. Inc., 1977, fig. II-74).

Water levels in the aquifer range from a few feet below land surface where the aquifer crops out in Evacuation Creek to more than 400 feet below land surface a few miles to the west (VTN, Colorado, Inc., 1977, fig. II-75).

The aquifer is probably overlain by a water-table aquifer in the Uinta Formation in most of the area. The vertical hydraulic conductivity of the confining bed overlying the bird'snest aquifer was calculated by the ground-water model to be about $3.32 \times 10^{-11}$ foot per second. The thickness of the confining bed is estimated to be about 150 feet.

Recharge to the bird's-nest aquifer in the southeastern Uinta Basin originates primarily from infiltration of streamflow from Evacuation Creek through thin alluvial deposits overlying the aquifer and downward leakage from the Uinta Formation. Precipitation falling on the outcrop area of the bird's-nest aquifer averages less than 12 inches per year and probably accounts for an insignificant amount of total recharge. Upward leakage from the Douglas Creek aquifer is assumed to be insignificant because of the minute vertical hydraulic conductivities of the fine-grained marlstones and oil-shale beds separating the two aquifers.

Discharge from the bird's-nest aquifer in the southeastern Uinta Basin primarily is by upward leakage through the Uinta Formation and alluvial aquifers to Bitter Creek and discharge to the White River. A number of small springs discharge water from the bird's-nest aquifer into Evacuation Creek but the amount of discharge is small.

Recharge to and discharge from the aquifer were estimated from a ground-water model. Values obtained from the model were compared to streamflow measurements to verify model results whenever possible.

A summary of the ground-water budget for the bird'snest aquifer with long-term averages obtained from the groundwater model is presented in table 7. Subsequent sections of this report will discuss the budget components in more detail.

Table 7. Summary of ground-water budget for the bird's-nest aquifer

\begin{tabular}{|c|c|}
\hline Component & $\begin{array}{l}\text { Long-term average } \\
\text { (acre-feet peryear) }\end{array}$ \\
\hline \multicolumn{2}{|l|}{ Recharge: } \\
\hline Infiltration from Evacuation Creek ... . & 420 \\
\hline Downward leakage from Uinta Formation & 250 \\
\hline Upward leakage from Douglas Creek aquifer & . Insignificant \\
\hline Precipitation falling on the outcrop area & . Insignificant \\
\hline Total $\quad \ldots \quad \ldots \ldots$ & $\ldots \quad \ldots 70$ \\
\hline \multicolumn{2}{|l|}{ Discharge: } \\
\hline Upward leakage to White River and associated alluvial aquifer. & 30 \\
\hline Upward leakage to Bitter Creek and assocaited alluvial aquifer & 640 \\
\hline Total $\ldots \ldots \quad \ldots \ldots \ldots$ & 670 \\
\hline
\end{tabular}




\section{Recharge}

Recharge to the bird's-nest aquifer is from infiltration of streamflow from Evacuation Creek and downward leakage from the Uinta Formation. Upward leakage from the Douglas Creek aquifer and precipitation falling on the outcrop of the aquifer probably are insignificant as sources of recharge.

\section{Infiltration from Evacuation Creek}

Recharge from infiltration of streamflow along Evacuation Creek was estimated by the ground-water model to be 420 acre-feet per year. Streamflow losses between gaging stations $09.306+10$ and $09306+30$ on Evacuation Creek (pl. 1 ) measured during January 1975-79 amounted to an average rate of 240 acre-feet per year. January records were used because evapotranspiration and tributary inflow were minimal during that month. The difference between recharge computed by the model and recharge computed using average January streamflow records may be the result of a seasonal variation in recharge. Mean-January discharge at station $09.306+30$ is less than 5 percent of the mean annual discharge. Therefore. recharge probably is greater at other times of the year when a larger amount of streamflow covers a larger part of the channel, thus allowing greater infiltration.

\section{Downward leakage from the Uinta Formation}

Recharge to the hird's-nest aquifer by downward leakage from the Linta Formation was estimated by the ground-water model to he about $25($ ) acre-feet per year. Water leaking into the aquifer from the Uinta Formation probably originates from infiltration of perennial streamflow, primarily the White River. but the amount of recharge is so small compared to the flow of the river that streamflow records cannot be used to verify the amount calculated by the model.

\section{Movement}

Water in the bird's-nest aquifer probably moves to the west from recharge areas along Evacuation Creek. and from the south and north toward discharge areas in the lower reaches of Bitter Creek. The direction of ground-water movement may be controlled locally by fracture systems that act as drains. although data is insufficient to verify this.

\section{Storage}

The amount of recoverable water stored in the bird'snest aquifer is estimated to be about 1.9 million acre-feet. This estimate is based upon an areal extent of 300 square miles of the aquifer (VTN. Colorado. Inc.. 1977. fig. 11-72), a specific yield of 0.1 , and an average thickness of 100 feet (VTN. Colorado, Inc., 1977, table II-14).

Changes in water levels in the bird's-nest aquifer result from seasonal variations in the balance between recharge and discharge and from changes in barometric pressure (VTN, Colorado, Inc.. 1977, fig. II-84). Water-level fluctuations corrected for barometric fluctuations at two observation wells completed in the bird's-nest aquifer compared with discharge on the White River at gaging station 09306500 during the 1978 water year are shown in figure 11 .

\section{Discharge}

Discharge from the bird's-nest aquifer is to the White River, and to Bitter Creek by upward leakage.

\section{White River}

Discharge from the bird's-nest aquifer to the White River was estimated by the ground-water model to be 30 acre-feet per year. The discharge occurs near the mouth of Evacuation Creek where the river crosses the outcrop of the aquifer.

\section{Upward leakage to Bitter Creek}

Discharge from the bird's-nest aquifer to Bitter Creek and associated alluvial aquifer was estimated by the groundwater model to be 640 acre-feet per year. The discharge occurs in the downstrean reaches of Bitter Creek where water from the aquifer moves through the Uinta Formation into the alluvial aquifer and discharges from springs in the bottom of the stream channel. Streamflow records from continuous-gaging station $0930685(0)$ in Bitter Creek (pl. 1 ) show an annual flow of about 580 acre-feet per year (Lindskov and Kimball. 1982. table 2). This flow is derived almost entirely from spring (D-10-22) $15 \mathrm{ddd}-\mathrm{S} 1$. which discharges about 1.5 miles upstream. Because of the relatively constant discharge of the spring, it is probable that most of the water is derived from underlying consolidatedrock aquifers. In the area of the spring. a gilsonite dike cuts vertically across the Uinta Formation (Price and Miller. 1975. pl. 1). It is prohable that fractures related to the dike transmit water from the bird's-nest aquifer through the Uinta Formation and the alluvial aquifer to the spring. Discharge from the bird's-nest aquifer to the alluvial aquifers along Bitter Creek also is discussed under the mass-transfer model later in this report.

\section{Digital-computer model of flow system}

The digital-computer model used for the flow systems in the bird's-nest and Douglas Creek ayuifers was developed by Trescott. Pinder. and Larson (1976). The model is two-dimensional and can be used to simulate ground-water flow in an artesian aquifer, a water-table aquifer, or a combined artesian and water-table ayuifer. The model takes into account leakage from confining beds, leaky streambeds, constant recharge. evapotranspiration, and well discharge.

Data requirements for simulation of an artesian aquifer include transmissivity. storage coefficient. recharge. discharge. boundary locations and conditions. and initial head values. For 

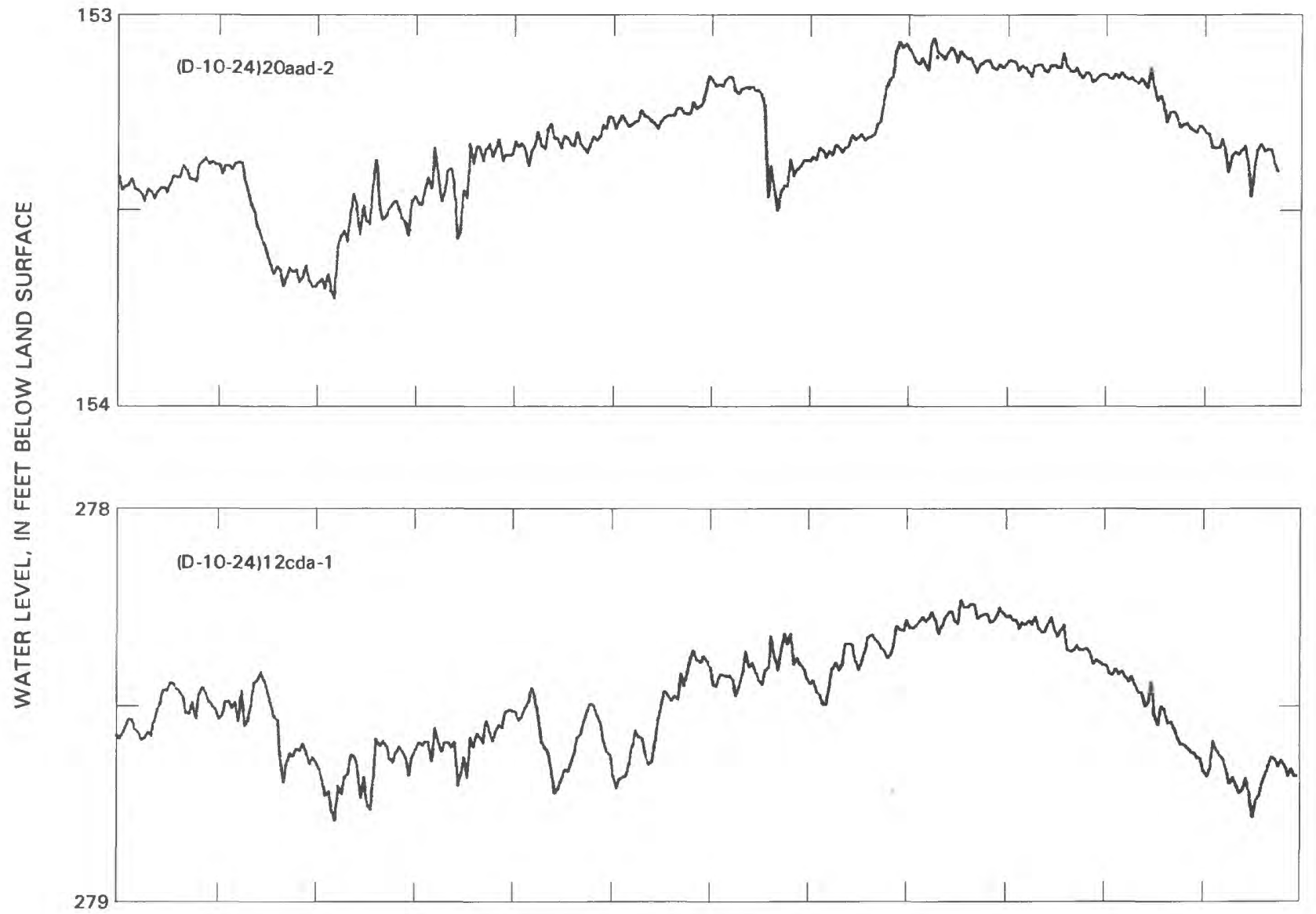

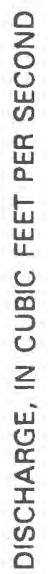

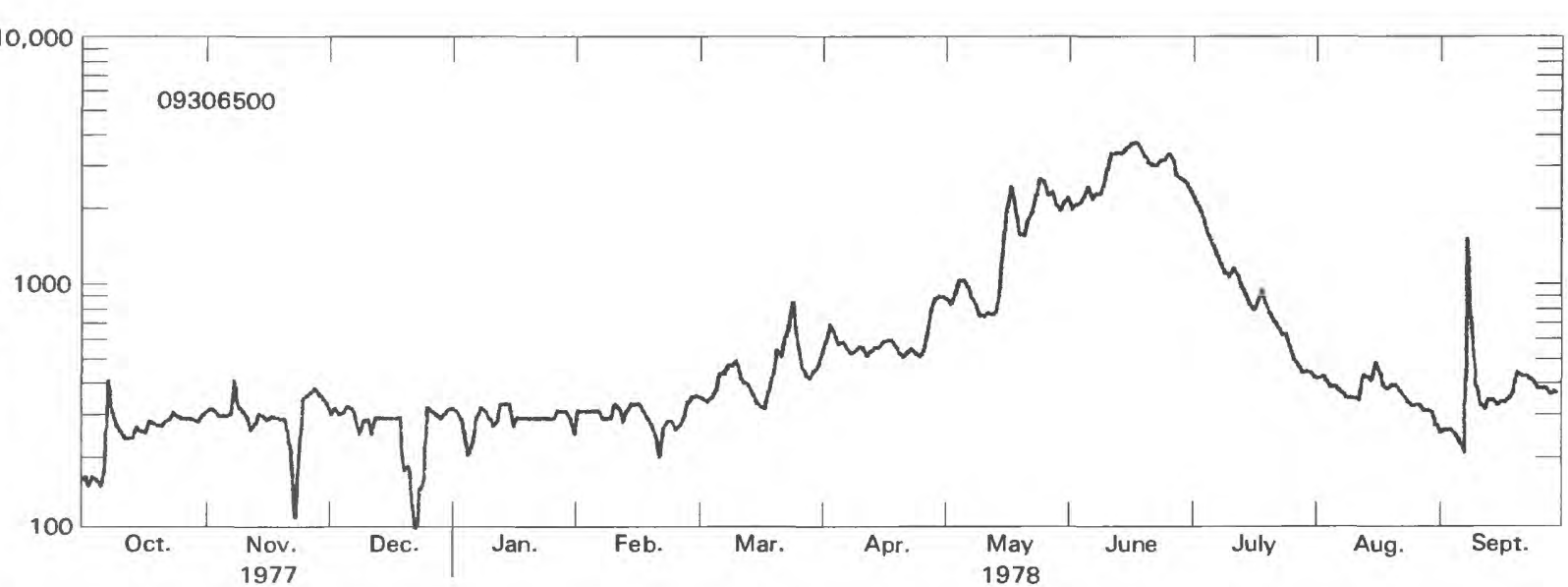

Figure 11. Relation of water levels in wells (D-10-24)20add-2 and (D-10-24)12cda-1, corrected for changes in barometric pressure, to discharge of White River at gaging station 09306500.

water-table simulations, or combined water-table and artesian aquifers. input data also needs to include altitude of the top and bottom of the aquifer and specific yield. When leakage is used in the model, the vertical hydraulic conductivity of the confining bed, the water level about the leaky streambed, and thickness of the confining bed also need to be included.

\section{Design}

A simulation of combined artesian and water-table aquifers with a leaky confining bed overlain by a water-table aquifer was used to model the flow system in the bird's-nest aquifer. Only the area where the aquifer has been identified in test 


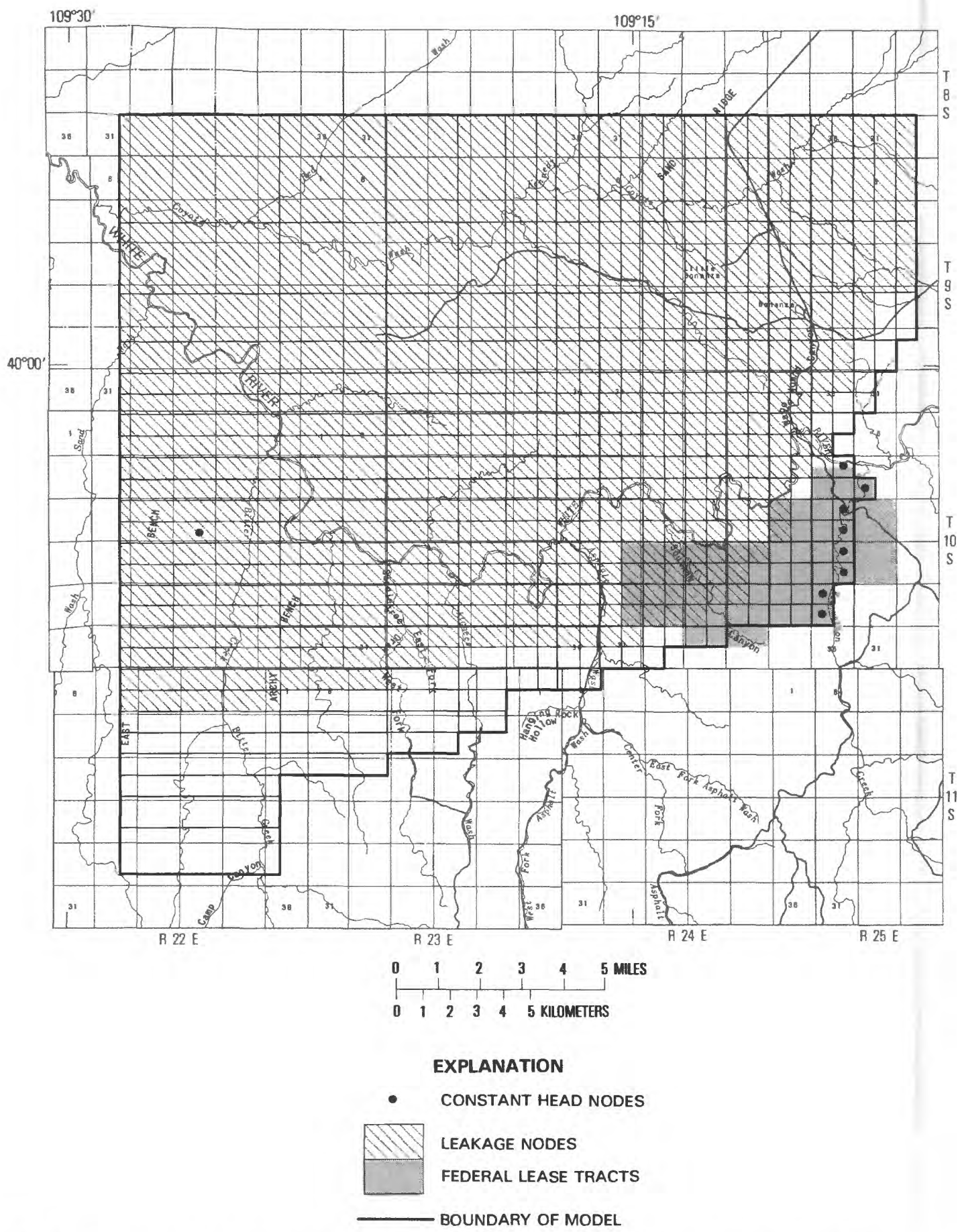

Figure 12. Aquifer boundaries, grid size, constant-head nodes, and leakage nodes used in the digitalcomputer model of the bird's-nest aquifer.

holes was modeled. The aquifer boundaries, grid size, constanthead nodes, and leakage nodes used in the digital-computer model are shown in figure 12. Input data for the model included initial heads, hydraulic conductivity, storage coefficient, vertical hydraulic conductivity of the confining bed, thickness of aquifer, thickness of confining bed, and heads in the watertable aquifer (altitude of water levels above a leaky streambed).
Values of hydraulic conductivity and storage coefficient used in the model are based on aquifer test results (VTN, Colorado. Inc., 1977, table II-13). These calculated hydraulic conductivities were then extrapolated throughout the entire area modeled. Because of the variability of the calculated hydraulic conductivities, and the necessity of using average values of hydraulic conductivity over the area of each grid 


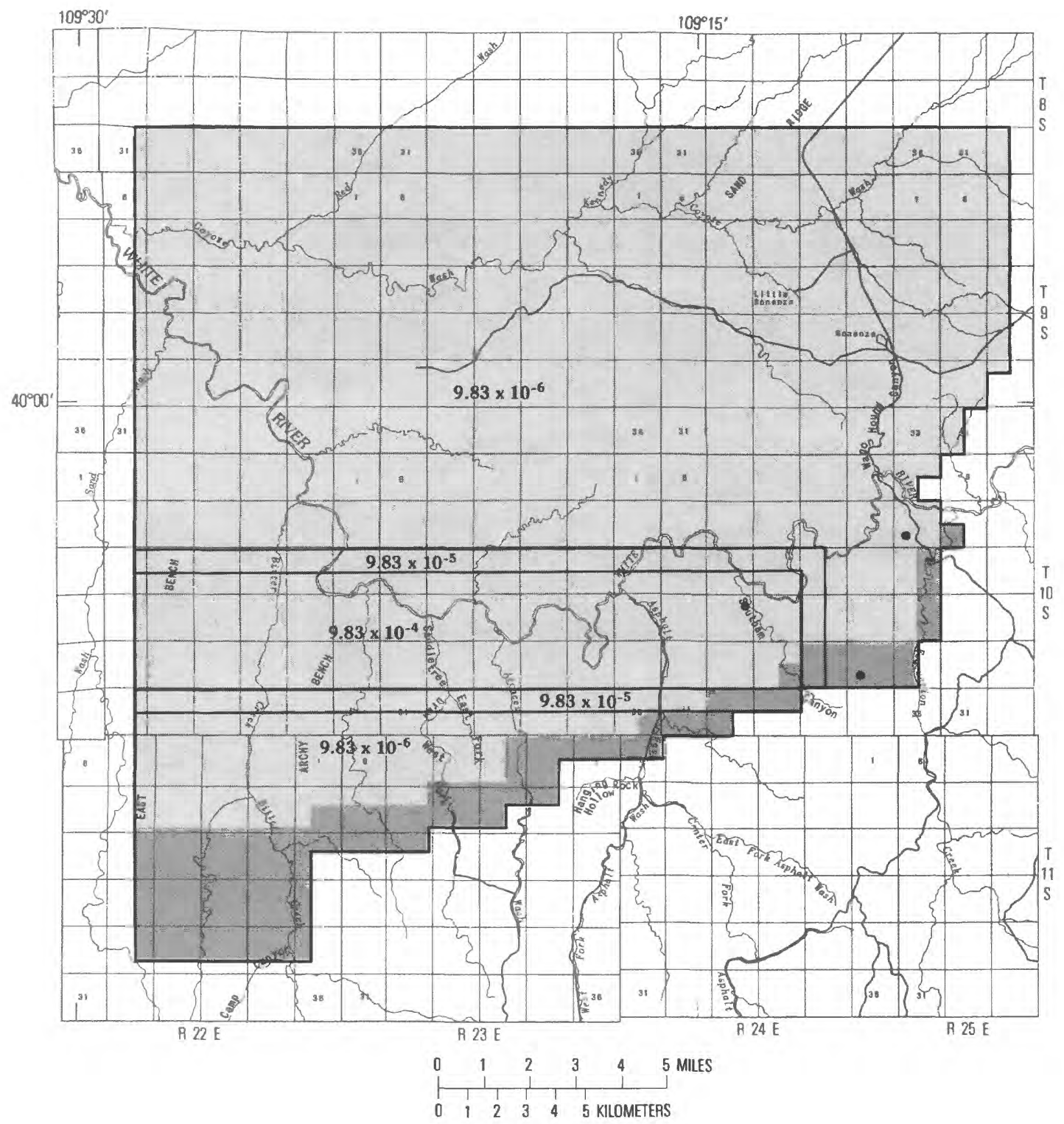

EXPLANATION

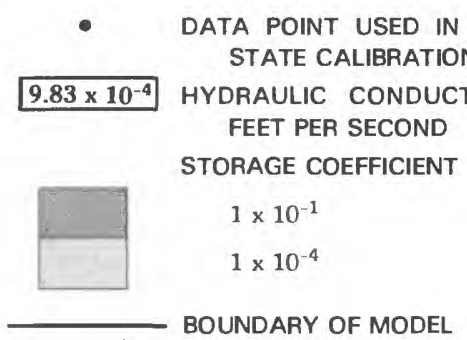

Figure 13. Hydraulic conductivity and storage coefficient of the bird's-nest aquifer used in the digitalcomputer model.

block, the results of point tests do not correspond exactly to the values used in the model. The distribution of hydraulic conductivity used in the model is shown in figure 13 .

Uniform values of storage coefficient were assigned to the artesian and water-table parts of the aquifers (VTN, Colorado, Inc., 1977, table II-74). A storage coefficient of $1 \times 10^{-4}$ was used for the artesian part and (a specific yield of) $1 \times 10^{-1}$ was used for the water-table part of the system (fig. 14). These 
values generally agree with the values obtained during aquifer tests (VTN. Colorado, Inc., 1977, table II-13).

The vertical hydraulic conductivity of the confining layer between the water-table aquifer and the bird's-nest aquifer was calculated during steady-state calibration. A vertical hydraulic conductivity of $3.32 \times 10^{-10}$ foot per second was used at all leakage points in the model.

Sensitivity analyses performed during the steady-state calibration indicate the vertical hydraulic conductivity could range from 0 to $3.32 \times 10^{-8}$ foot per second. Results of simulations reported later in this report should be used with caution because under transient simulations the model is highly sensitive to vertical leakage.

Constant-head nodes were used during calibration to establish rates of recharge and discharge in areas where the aquifer is in direct contact with the streambed. A constanthead node also was used near the western boundary of the model. near Bitter Creek. to simulate discharge into the Bitter Creek alluvial aquifer (fig. 12). During transient simulations. constant-head nodes along Evacuation Creek where recharge is limited by streamflow and the constant-head node near Bitter Creek were replaced with constant-flow nodes. The values of flow at each node were determined from the steadystate solution.

The boundaries of the model approximate the area outlined by structure contours given by VTN, Colorado, Inc., (1977, fig. II-72). The southern and eastern boundaries are no-flow boundaries where the aquifer crops out at the surface. The northern and western boundaries are somewhat arbitrary due to lack of data, and they represent the best estimate of these two limits of the aquifer. No-flow boundaries also were placed on the northern and western edges of the modeled area.

\section{Calibration}

Historic water-level data were not available to use in the calibration of the model. Little ground water has been pumped from the area, thus the system is assumed to be in a steady-state condition. This condition was simulated by setting all storage terms to zero. The computed steady-state water-level configuration thus was dependent only upon transmissivity, vertical hydraulic conductivity, and boundary conditions.

Calibration of the model was accomplished by varying transmissivity and vertical hydraulic conductivity within a range similar to that indicated by results of aquifer tests, while keeping other variables constant. The computed heads were then compared to actual heads that were measured during March 1975 (VTN, Colorado, Inc., 1977, fig. II-75).

The final steady-state solution for the potentiometric surface and the distribution of recharge and discharge are shown in figures 14 and 15. The potentiometric surface simulated by the model generally is within 10 feet of measured values. and only one water level differed by more than 20 feet from the measured value. Considering that transmissivity changes rapidly in short distances and computed water levels are averages for a nodal area, the solution is a reasonable representation of the actual aquifer.

The results of the steady-state model indicate that recharge from infiltration of streamflow along Evacuation Creek (fig.
15 ) is 420 acre-feet per year. The model also indicates an additional 250 acre-feet per year of recharge from downward leakuge from the overlying Uinta Formation.

The model indicates that discharge from the aquifer to the White River is 30 acre-feet per year, while discharge by upward leakage to Bitter Creek is 640 acre-feet per year.

\section{Simulated effects of oil-shale development}

Simulated effects of oil-shale development in Federal lease tracts $\mathrm{Ua}$ and $\mathrm{Ub}$ on the bird's-nest aquifer include: (1) Dewatering of the aquifer when penetrated during construction of a vertical shaft. (2) construction of a reservoir on the White River near the mining area, or (3) use of ground water to supply the water requirements of mining and processing of ore. The effects of dewatering the mining zone beneath the bird'snest aquifer could not be simulated by the model because data are insufficient to determine vertical hydraulic conductivities between the mining zone and the bird's-nest aquifer.

\section{Dewatering}

The construction of a vertical access shaft to mine oil shale (White River Shale Project, undated, fig. 3.4-2) would require some dewatering when the shaft penetrates the bird'snest aquifer which lies about 400 feet above the mining zone. The shaft is postulated in sec. 22, T. 10 S.. R 24 E. (White River Shale Project, undated, fig. 3.4-1). To simulate dewatering, a pumping well was located in the same node as the shaft, and a pumping rate capable of lowering the water level to the base of the aquifer after 1 year was determined. The simulation indicates that by dewatering at a rate of about 900 gallons per minute. the aquifer in the immediate vicinity of the shaft would be dewatered. Drawdowns after 1 year of dewatering would be as great as 40 feet at a distance of 1 mile. and 10 feet at a distance of 5 miles. If the walls of the shaft are sealed as it is being constructed, however, the rate of pumping needed to dewater the shaft would be substantially smaller. The effects of dewatering the mining zone beneath the bird's-nest aquifer were not simulated.

Sensitivity analyses were performed to evaluate the simulated model responses to ranges in transmissivity. storage coefficient, and vertical hydraulic conductivity. The ranges used in the sensitivity analyses reflect the confidence in the data. The analyses show that a two-fold increase or decrease in transmissivity increases or decreases the pumping rate needed to dewater the shaft by the same proportion. A 10 -fold increase or decrease in vertical hydraulic conductivity or storage coefficient has almost no effect on the pumping needed to dewater the shaft.

\section{Reservoir construction}

The construction of a reservoir on the White River near Federal lease tracts $\mathrm{Ua}$ and $\mathrm{Ub}$ may alter the present head distribution in the bird's-nest aquifer. To simulate the effect of such a reservoir on the bird's-nest aquifer, the altitude of the 


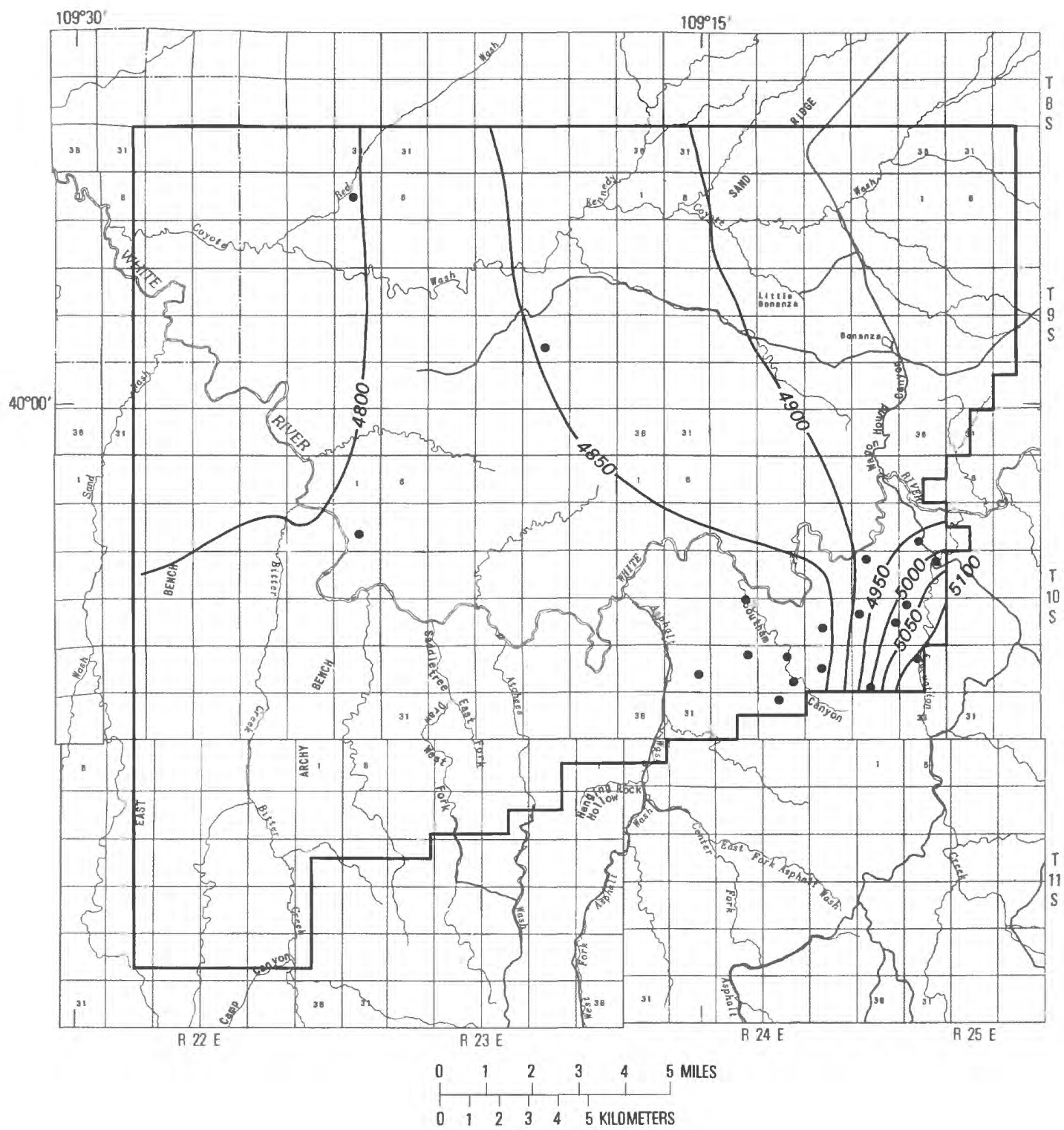

EXPLANATION

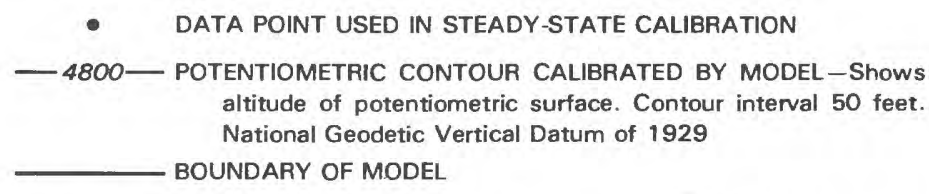

Figure 14. Potentiometric-surface contours of the bird's-nest aquifer computer by the digitalcomputer model.

water-table aquifer near the White River was increased to reflect the altitude of the water surface in the reservoir at full capacity.

Results of the simulations indicate that after 20 years water levels in the bird's-nest aquifer near the reservoir site would rise by as much as 45 feet and leakage from the overlying Uinta Formation would double if the vertical hydraulic conductivity were $3.32 \times 10^{-x}$ foot per second; or, water levels in the bird's-nest aquifer would be unchanged if the vertical hydraulic conductivity were zero.

\section{Water supply}

Water requirements for commercial production of oil shale on Federal lease tracts $\mathrm{U}$ a and $\mathrm{Ub}$ have been estimated at between 13.000 and 26,000 acre-feet per year (White River 


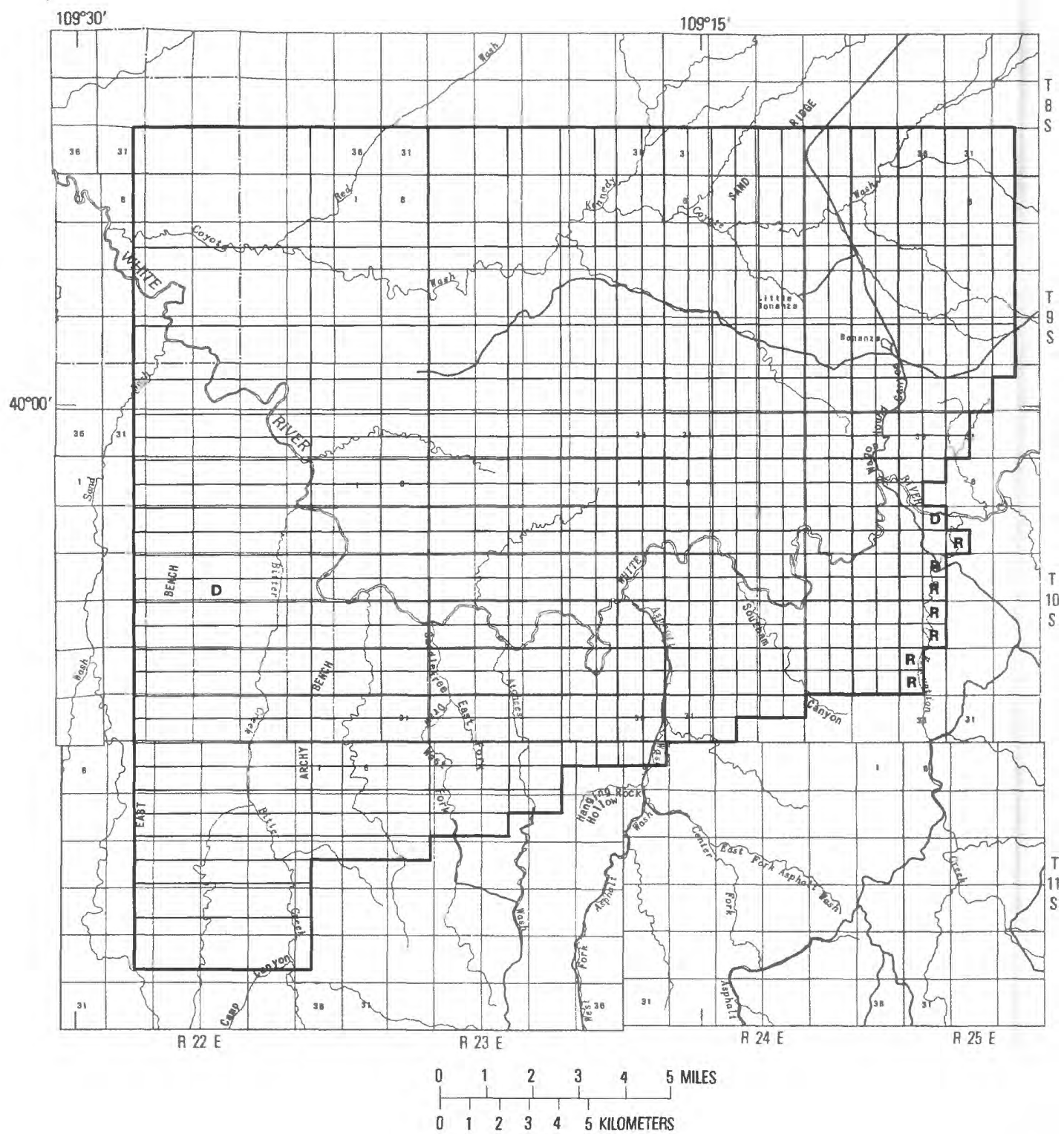

EXPLANATION

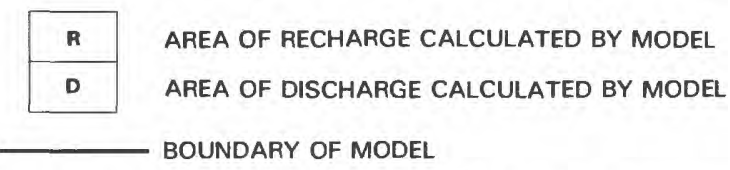

Figure 15. Distribution of recharge and discharge, computed by the digital-computer model for the bird's-nest aquifer.

Shale Project, undated, p. 7.14-21. A source of supply is from a reservoir on the White River. An alternative source is ground water. The model was used to evaluate the potential of the bird's-nest aquifer to yield large amounts of water for oil-shale development. This simulation did not include a reservoir on the White River. Ten wells were simulated in areas of largest transmissivity near the White River. Each of the wells was in the center of a node, and only one well per node was simulated.

Results of the simulation indicate that the aquifer is capable of supplying about 10.000 acre-feet per year, or about 80 percent of the minimum requirement for oil-shale development of Federal lease tracts $\mathrm{Ua}$ and $\mathrm{Ub}$ for the planned 20-year mining operation. At the end of 20 years, the water levels in the simulated wells would be near the base of the aquifer.

Pumping 10.000 acre-feet per year from the bird's-nest aquifer would cause a significant decline in the potentiometric surface throughout the modeled area. The drawdown computed by the model for the bird's-nest aquifer after 20 years of 


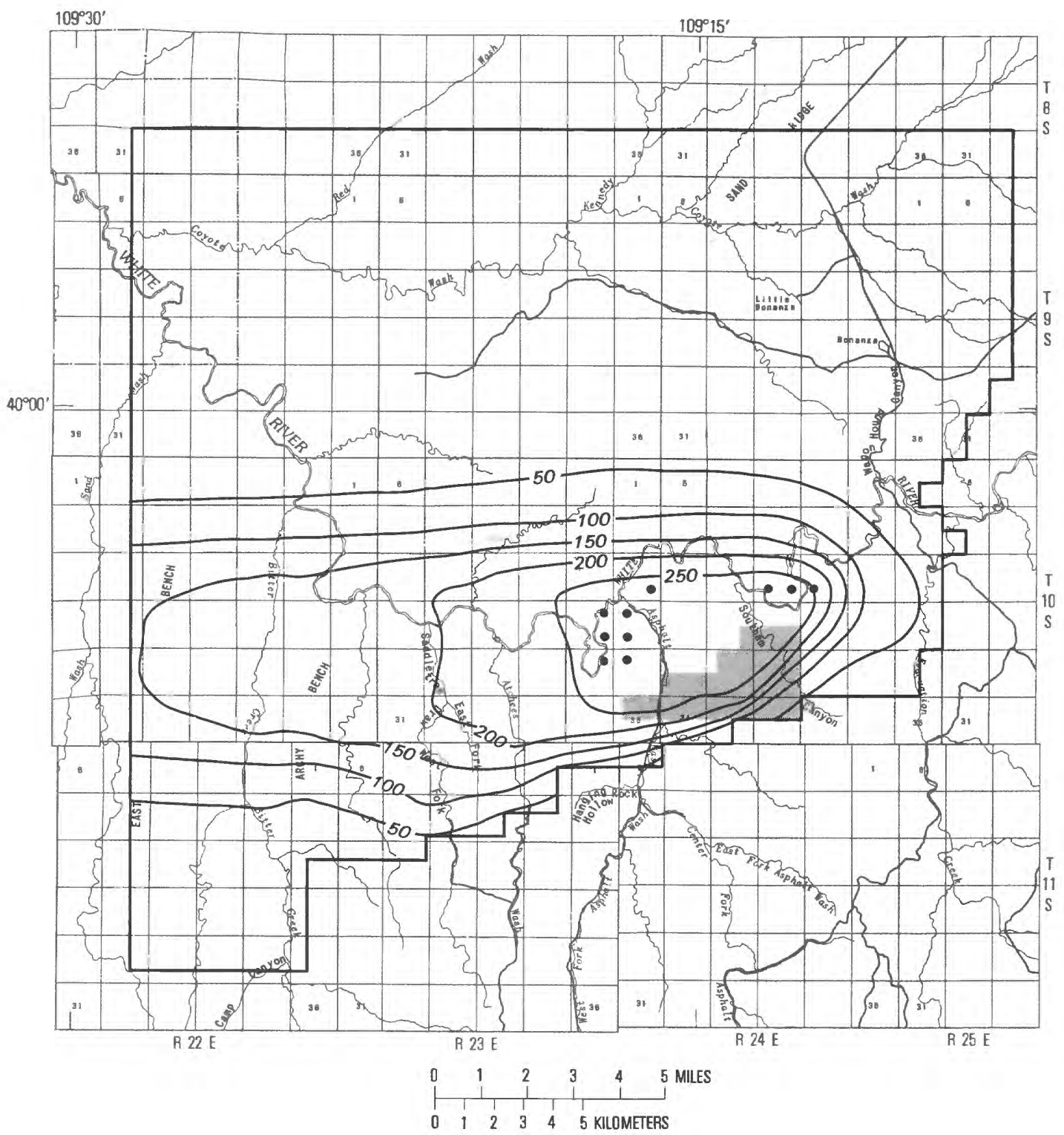

EXPLANATION

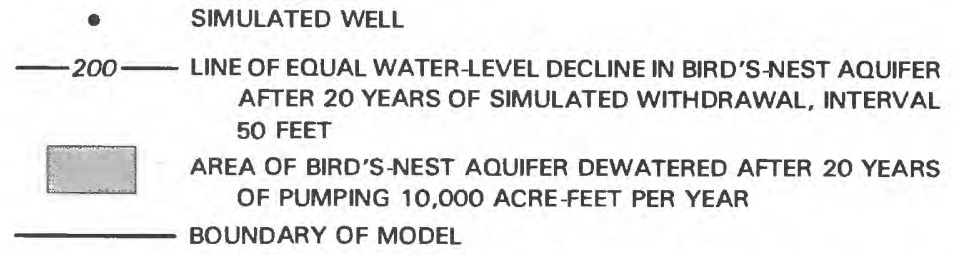

Figure 16. Drawdown in the bird's-nest aquifer after 20 vears of simulated withdrawals, computed by the digital-computer model.

simulated withdrawals is shown in figure 16 . Declines after 20 years of pumping in about 10 square miles near the well field would exceed 250 feet. Declines at the boundaries of the modeled area would range from about 20 to 200 feet. After 20 years of pumping, about 5 square miles of the aquifer would be completely dewatered.
The decline of the potentiometric surface of the bird'snest aquifer would have a significant effect on recharge (leakage) to the aquifer from the Uinta Formation. Initially, most of the 10,000 acre-feet per year would be removed from aquifer storage. As pumping continued and the potentiometric surface declined, leakage to the aquifer from the Uinta Formation 
would increase. After 20 years of pumping, about 62 percent of the water would be supplied by leakage from the Uinta Formation. Since recharge to the Uinta Formation is probably from perennial streamflow, a reduction in streamflow can be expected.

The amount of available water from the bird's-nest aquifer for a period of 20 years is estimated to be about 20,000 acre-feet per year. The estimate assumes that an additional pumping center in the northern part of the modeled area (fig. 16) could withdraw an additional 10,000 acre-feet per year although some inte:ference between pumping centers could be expected. The poor quality of water in the bird's-nest aquifer in the northern part of the area may be a limiting factor.

A sensitivity analysis was performed to evaluate the model responses to changes in the vertical hydraulic conductivity of the confining layer and the specific yield and horizontal hydraulic conductivity of the aquifer. The model is sensitive to vertical hydraulic conductivity of the confining layer. If the values were increased by a factor of 10 , the aquifer would be capable of providing all of the minimum requirement of 13,000 acre-feet per year for the 20-year period. If the value were decreased by a factor of 10 , the aquifer would be capable of supplying substantially less water for oil-shale development during 20 years. If the reservoir on the White River was in place during pumping, the yields would be higher.

The model also is sensitive to specific yield. If the specific yield of the aquifer were 0.15 instead of the estimated 0.1 . the aquifer would be capable of supplying about 13.000 acrefeet per year, or 100 percent of the minimum requirement. If the specific yield were 0.05 , the maximum production would be limited to about 9,000 acre-feet per year, or about 70 percent of the minimum requirement.

The model also is sensitive to changes in hydraulic conductivity. If hydraulic conductivities were double the values shown in figure 13, the aquifer would be capable of supplying about 13,000 acre-feet per year, or 100 percent of the minimum requirement. If hydraulic conductivities were onehalf the values shown in figure 13. the aquifer would be capable of supplying about 9.000 acre-feet per year, or about 70 percent of the minimum requirement.

The model boundaries also affect the simulated results. If the aquifer exists beyond the boundaries used in the model, the decline in water levels throughout the area would be substantially decreased. Also, a maximum of 640 acre-feet per year discharging to Bitter Creek and associated alluvial aquifer (p. 80) may be intercepted by lowering water levels in the area. Drawdown in the bird's-nest aquifer near the western border of the model (fig. 16) would be slightly less than computed by the model.

\section{Quality}

\section{Chemical and Physical Characteristics}

There generally are two types of water in the bird's-nest aquifer, and they differ greatly in dissolved-solids concentration and chemical character. The digital-computer model indicates that the local flow in the aquifer in T. 10 S.. R. 24 E., sec. 20 , 21,28 , and 29 (fig. 14) is from the northeast to the southwest.
The varied chemical character of the water in part of the bird's-nest aquifer can be seen in the patterns shown in figure 17. In the northeast, dominant ions are sodium and sulfate. and dissolved-solids concentration has a mean of about 3.800 milligrams per liter. This changes to the southwest, where the dominant ions are sodium and bicarbonate and the mean dissolved-solids concentration is about 1,600 milligrams per liter. The dilution probably is caused by downward leakage from the overlying Uinta Formation (table 7) which is probably recharged locally by the White River.

The quality of water in the bird's-nest aquifer is summarized in table 8 . The $\mathrm{pH}$ changes from a mean of 7.8 in the northeast to a mean of 8.9 in the southwest. Water temperature increases from a mean of $13.5^{\circ} \mathrm{C}$ in the northeast to a mean of about $16.5^{\circ} \mathrm{C}$ in the southwest.

All the major constituents are less concentrated in the southwest than in the northeast part. Some of the major constituents show a simple pattern of dilution when the aquifer water is diluted by recharge from the overlying Uinta Formation which is probably recharged by the White River, whereas other solutes do not show a simple pattern of dilution. The major alkaline-earth metals, calcium and magnesium, are nearly absent in the southwest. The mean concentration of sulfate also is much less than would be expected from dilution alone. In contrast. alkalinity (mostly as bicarbonate and carbonate ions) is greater in the southwest. The increase of bicarbonate and carbonate is due to sulfate reduction. The large increase in bicarbonate contributes to the precipitation of the alkalineearth carbonates, and thus calcium and magnesium are removed from solution. Each of these processes is considered in the discussion of the mass-transfer model of the bird's-nest aquifer below.

Mean concentrations of trace constituents also are affected by the recharge from the Uinta Formation. However, the effect varies for the different constituents. Mean concentrations of iron decreased from 646 micrograms per liter in the northeast to 137 micrograms per liter in the southwest. and boron has a corresponding decrease from 5,515 to 2,140 micrograms per liter. Strontium decreased from about 6.170 to 1.530 micrograms per liter in the same direction, and zinc also is diluted. Not all trace elements are shown in table 8.

Mean concentrations of other trace elements actually increase from concentrations in the recharge area. Lithium increased from about 350 to about 490 micrograms per liter from the northeast to the southwest. Arsenic increased from about 9 to about 30 micrograms per liter. These increases might be attributed to the release of adsorbed trace elements with the decrease in ionic concentration of the water from northeast to southwest. At smaller dissolved-solids concentrations and smaller concentrations of sodium, calcium, and magnesium are more successful in competing for exchange sites on the clays. Perhaps the release of these trace elements is a result of the replacement by calcium and magnesium on exchange sites.

The nutrient concentrations of the waters in the bird'snest aquifer are small. In the northeast, the mean concentration of nitrate is 1.87 milligrams per liter as $\mathbf{N}$, while the concentration of ammonia is 0.75 milligram per liter as $\mathrm{N}$. To the southwest, the mean concentration of nitrate is 0.02 milligram per liter as $\mathrm{N}$, while ammonia is 1.3 milligrams per liter as 

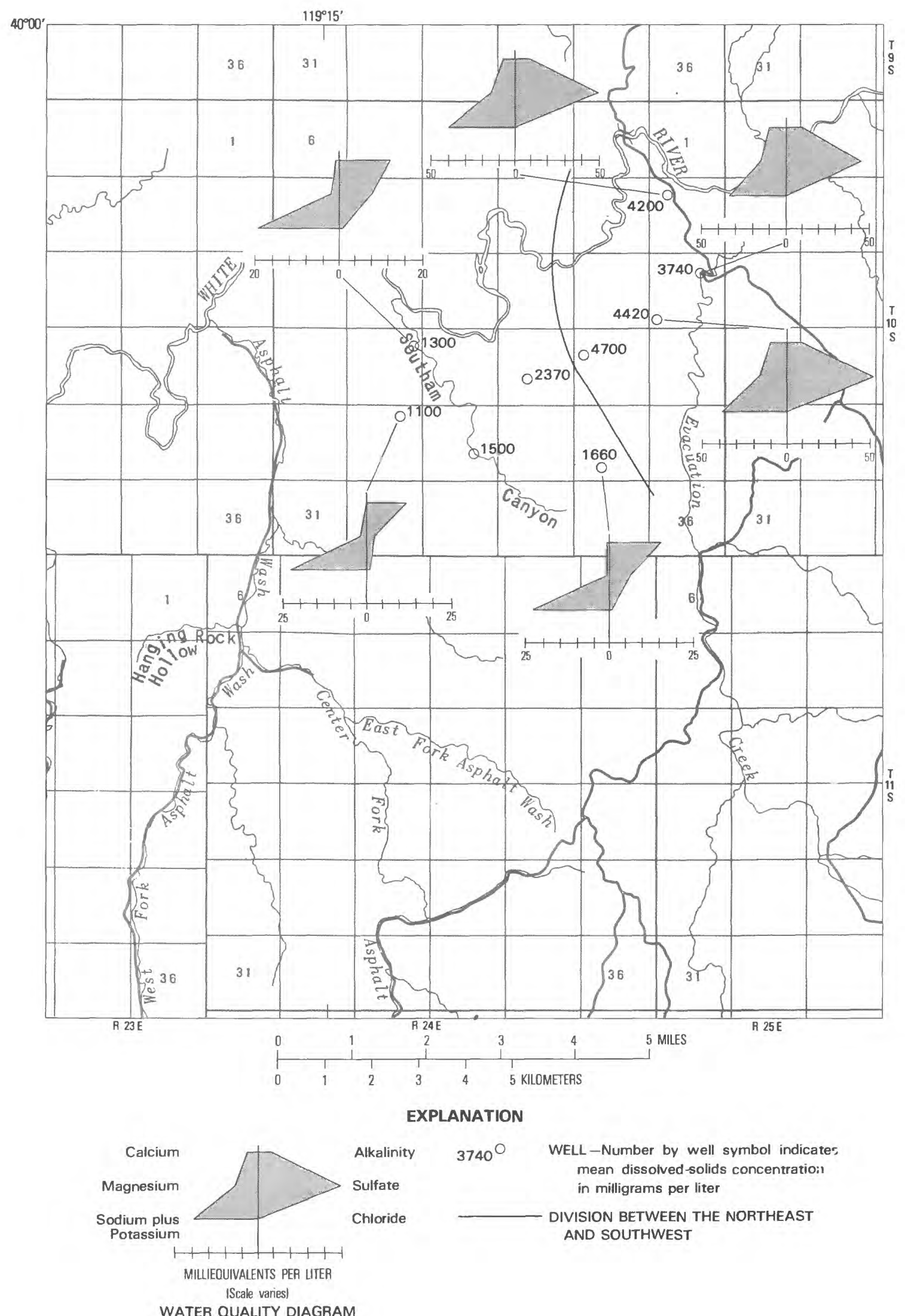

Figure 17. Variation in mean dissolved-solids concentrations and chemical character of water in part of the bird's-nest aquifer. 
Table 8. Summary of chemical quality of water in the bird's-nest aquifer

\begin{tabular}{|c|c|c|c|c|c|c|}
\hline \multirow[b]{2}{*}{ Variable } & \multicolumn{3}{|c|}{ Northeast } & \multicolumn{3}{|c|}{ Southwest } \\
\hline & $\begin{array}{c}\text { Number } \\
\text { of samples }\end{array}$ & Mean & $\begin{array}{l}\text { Minimum- } \\
\text { maximum }\end{array}$ & $\begin{array}{c}\text { Number } \\
\text { of samples }\end{array}$ & Mean & $\begin{array}{l}\text { Minimum- } \\
\text { maximum }\end{array}$ \\
\hline Water temperature (degrees Celsius). & $\ldots 41$ & 13.5 & $10.0-19.0$ & 36 & 16.3 & $13.0-19.5$ \\
\hline \multicolumn{7}{|c|}{ Specific conductance (micromhos } \\
\hline per centimeter at $25^{\circ} \mathrm{C}$ ) $\ldots \ldots \ldots$ & 44 & 4,772 & $1,130-6,900$ & 36 & 2,542 & $1,270-6,460$ \\
\hline $\mathrm{pH}$ (log units) . . . . . . . . . . . . & ... 40 & 17.8 & $7.2-8.4$ & 38 & 18.9 & 7.4-10.7 \\
\hline \multicolumn{7}{|c|}{ Milligrams per liter } \\
\hline Alkalinity $\left(\right.$ as $\left.\mathrm{CaCO}_{3}\right) \ldots \ldots$ & $\therefore .44$ & 594 & $216-1,970$ & 39 & 859 & $368-3,010$ \\
\hline Hardness (as $\left.\mathrm{CaCO}_{3}\right) \ldots \ldots \ldots$ & $\therefore .44$ & 1,031 & $250-1,500$ & 39 & 78 & $2-210$ \\
\hline Calcium (as Ca) $\ldots \ldots \ldots \ldots \ldots$ & $\ldots .44$ & 138 & $15-210$ & 39 & 10 & $0.1-75$ \\
\hline Magnesium (as $\mathrm{Mg}$ ) . . . . . . . . . . & $\ldots 44$ & 167 & $0.0-260$ & 39 & 12 & $0.3-32$ \\
\hline Sodium (as $\mathrm{Na}$ )..... & .. 44 & 876 & $72-1,800$ & 39 & 607 & $300-1,700$ \\
\hline Potassium (as K) . & .44 & 7.4 & $2.3-13$ & 39 & 2.4 & 1.1-8.1 \\
\hline Chloride (as $\mathrm{Cl}) \ldots \ldots \ldots \ldots$ & $\ldots 44$ & 75 & $36-280$ & 38 & 118 & $30-580$ \\
\hline Sulfate (as $\left.\mathrm{SO}_{4}\right) \ldots \ldots \ldots \ldots$ & $\ldots 44$ & 2,181 & $180-3,100$ & 38 & 416 & $23-1,200$ \\
\hline Fluoride (as F) $\ldots \ldots$ & $\ldots 44$ & 1.7 & $0.2-11$ & 38 & 2.6 & $0.9-21$ \\
\hline Silica $\left(\right.$ as $\left.\mathrm{SiO}_{2}\right) \ldots \ldots$ & .44 & 16 & $7.4-28$ & 37 & 15 & $3.3-27$ \\
\hline Dissolved solids (calculated) & $\ldots 44$ & 3,817 & $438-5,812$ & 37 & 1,583 & $869-3,217$ \\
\hline Nitrogen, ammonia (as N) & $\ldots 44$ & .75 & $0.0-2.9$ & 39 & 1.3 & $0.4-5.6$ \\
\hline Nitrogen, nitrate $($ as $\mathrm{N}) \ldots \ldots \ldots \ldots$ & $\ldots 39$ & 1.87 & $0.0-30.0$ & 36 & .02 & $0.0-0.24$ \\
\hline \multicolumn{7}{|c|}{ Micrograms per liter } \\
\hline Boron (as B). & $\ldots 44$ & 5,515 & $30-78,000$ & 38 & 2,140 & $360-8.200$ \\
\hline Iron $($ as $\mathrm{Fe}) \ldots$. & $\ldots 44$ & 646 & $0.0-4,600$ & 39 & 137 & $0.0-730$ \\
\hline Manganese (as Mn) & $\ldots 44$ & 57 & $0.0-230$ & 37 & 31 & $0.0-250$ \\
\hline
\end{tabular}

'Geometric mean.

N. Thus, the nitrogen is present in the reduced form to the southwest. The concentration of phosphorus averages about 0.1 milligram per liter in the northeast and about 0.3 milligram per liter in the southwest. Dissolved organic carbon has a mean of 15 milligrams per liter in the northeast and is about 11 milligrams per liter in the southwest. The organic carbon was diluted by downward leakage of water from the overlying Uinta Formation and also participates in the sulfate reduction reaction that is described more fully below.

The water generally is not suitable for irrigation or municipal use. Sulfate and dissolved-solids concentrations exceed the recommended drinking-water standards of the U.S. Environmental Protection Agency (1977, p. 205). In the northeast. the water is extremely hard, and the alkalinity is large. To the southwest, the hardness decreases greatly, and the water is soft, but the alkalinity increases. The water is suitable for industrial uses such as washing and cooling, but it would require treatment for use as boiler feed.

\section{Mass-Transfer Model}

All precipitation reactions except that for $\mathrm{Na}_{2} \mathrm{SO}_{4}$ (reaction 6), were modeled for the bird's-nest aquifer. An additional process also was considered. As the water in the bird's-nest aquifer generally moves down the hydraulic gradient from the east to the west, the dissolved-solids concentration generally decreases (fig. 17). This decrease is probably due to mixing of the water in the aquifer with fresh water from the White River, which leaks through the overlying Uinta Formation. This mixing and the precipitation reactions were modeled separately. whereas in the actual ground-water system they occur simultaneously. Also, since water-quality samples were not available from the Uinta Formation, it is impossible to identify what reactions actually may be occurring within the Uinta Formation and what reactions may be occurring within the aquifer itself.

Table 9 summarizes the mass-transfer model of the bird'snest aquifer. Water from wells in the aquifer in the northeast part of the area modeled was mixed with water from the White River in a ratio of 0.46 to 0.54 , respectively. This ratio was similar to that indicated by the model of the flow system and also by the changes in conservative elements, chloride and sodium. The mixed solution was then brought to equilibrium with sodium magnesium ion exchange. calcite. dolomite. and carbon dioxide, which was greater than the atmospheric pressure of carbon dioxide. At the same time, organic carbon with a valence of zero $\left(\mathrm{CH}_{2} \mathrm{O}\right)$ was added in the reaction. This caused reduction of the sulfate according to the reaction:

$$
15 \mathrm{CH}_{2} \mathrm{O}+2 \mathrm{Fe}_{2} \mathrm{O}_{3}+8 \mathrm{SO}_{4}^{2-}+\mathrm{H}_{2} \mathrm{CO}_{2} \rightleftharpoons 4 \mathrm{FeS}_{2}+16 \mathrm{HCO}_{3}^{-}+8 \mathrm{H}_{2} \mathrm{O}
$$

Hematite $\left(\mathrm{Fe}_{2} \mathrm{O}_{3}\right)$ was assumed to be a source of iron. but iron 
Table 9. Summary of mass-transfer model of the bird's-nest aquifer | Mean concentrations, in millimoles per liter unless noted: $\mathrm{meq} \mathrm{L}=$ milliequivalents per liter; log atm $=\log$ atmospheres]

\begin{tabular}{|c|c|c|c|c|c|}
\hline \multirow[b]{2}{*}{ Constituent } & \multirow[b]{2}{*}{$\begin{array}{c}\text { Northeast } \\
\text { (20 samples) }\end{array}$} & \multirow{2}{*}{$\begin{array}{c}\text { White River. } \\
09306500 \\
\text { (365 samples) }\end{array}$} & \multirow{2}{*}{$\begin{array}{l}\text { Mixed solution } \\
\text { Ratio 0.46-0.54 } \\
\text { (White River: } \\
\text { bird's-nest aquifer) }\end{array}$} & \multicolumn{2}{|c|}{ Southwest } \\
\hline & & & & $\begin{array}{c}\text { Analyzed } \\
\text { (13 samples) }\end{array}$ & Calculated \\
\hline Calcium & 3.960 & 1.764 & 2.774 & 0.207 & 0.204 \\
\hline Magnesium & 7.499 & 1.065 & 4.025 & .584 & .558 \\
\hline Sodium & 41.473 & 2.841 & 20.612 & 21.175 & 20.173 \\
\hline Chloride & 1.961 & 1.080 & 1.485 & 1.495 & 1.495 \\
\hline Alkalinity $(\mathrm{meq} / \mathrm{L})$ & 9.549 & 3.770 & 6.428 & 13.508 & 13.216 \\
\hline Sulfur (total) & 26.914 & 1.861 & 13.385 & 3.935 & 3.785 \\
\hline $\mathrm{pH}$ (log units). & 17.67 & 18.16 & ${ }^{1} 8.17$ & 18.74 & 18.74 \\
\hline PE (log units) $)^{2}$ & 7.593 & 8.357 & 8.357 & 5.77 & - \\
\hline Calcite saturation ${ }^{3}$. & .492 & .592 & .819 & .688 & - \\
\hline \multicolumn{6}{|l|}{ Dolomite } \\
\hline saturation & 1.274 & .867 & 1.742 & 1.819 & - \\
\hline \multicolumn{6}{|l|}{ Carbon dioxide } \\
\hline$(\log \mathrm{atm})$. & -2.0617 & -2.902 & -2.702 & -2.932 & - \\
\hline \multicolumn{6}{|c|}{ Mass transfer ${ }^{4}$} \\
\hline $\begin{array}{l}\text { Sodium-magnesium } \\
\text { ion exchange. }\end{array}$ & & & & & +.045 \\
\hline Calcite & & & & & +.851 \\
\hline Dolomite ... & & & & & -3.421 \\
\hline Carbon dioxide & & & & & -5.221 \\
\hline Hematite & & & & & +2.400 \\
\hline Pyrite & & & & & -4.800 \\
\hline
\end{tabular}

'Geometric mean.

2PE equals negative logarithm of the "electron" activity. See Stumm and Morgan (1981. Chapter 7).

"Represented as logarithm of the ion activity product divided by the equilibrium constant for each particular mineral. The ion activity products were calculated by PHREEQE (Parkhurst, Thorstenson, and Plummer. 1980).

"Mass transfer is the millimoles of each mineral dissolved (positive value) or precipitated (negative valuel.

from the carbonate minerals of the Green River Formation as described by Deshorough and Pitman11974) also could have been the source. Because no large increase in dissolved iron was observed in the water. pyrite ( $\left.\mathrm{FeS}_{2}\right)$ was assumed to be a sink for the iron and the reduced suifur.

This combination of reactions brought about an increase in $\mathrm{pH}$ and alkalinity. The change can be seen in the plot of alkalinity versus sulfate in figure 18 . The calculated reaction path is indicated. and it generally agrees with the observed data. The change in $\mathrm{pH}$ also can be compared with a decrease in chloride in figure 19. Part of the $\mathrm{pH}$ change is due to the mixing of river water with the aquifer water. hut apparently a carbonate-clay buffer increases the $\mathrm{pH}$, as in the alluvial aquifer.

The depletion of calcium and magnesium results from precipitation of calcite and dolomite and the exchange with sodium from the clay minerals. It is not clear if dolomite is actually being precipitated in the aquifer or if magnesium is merely controlled by precipitation of a high magnesium calcite or by sorption to clays. These reactions decrease the noncarbonate hardness (table 5). Because silica does not show a large variation. it was assumed that it is controlled in solution by sorption reactions on active surfaces of clays and quartz.

Because of the number of components and phases in this model, the solution composition is determined by fixing only one of the parameters, the partial pressure of carbon dioxide. Thus, in a sence, a solution to the mass transfer is forced on the model. and the results represent only one of several possible solutions. The validity of the model is determined in part by the geochemical intuition used in selecting the reactions.

\section{Douglas Creek Aquifer}

The Douglas Creek aquifer was identified in six test holes drilled during 1975-781 Holmes, 1980). The aquifer underlies almost the entire southeastern Uinta Basin and may extend beyond the boundaries of the study area to the north and west. The aquifer crops out in the southern part of the study area at high altitudes. along the eastern border of the study area near the Utah-Colorado State line. along the western border of the study area in Desolation Canyon, and in the bottoms of deeply incised canyons in the central part of the study area.

The Douglas Creek aquifer consists of beds of sandstone and limestone of the Douglas Creek Member of the Green River Formation and some intertonguing sandstone of the Renegade Tongue of the Wasatch Formation. The top of the 


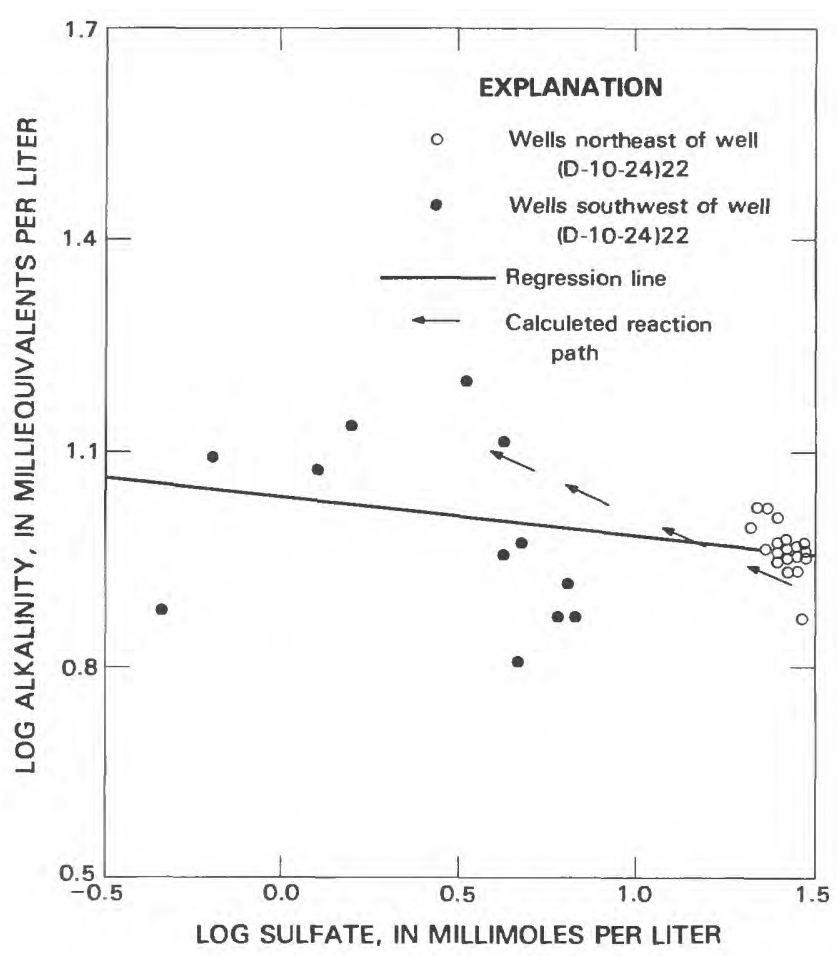

Figure 18. Plot of alkalinity versus sulfate in water from the bird's-nest aquifer showing the reaction path calculated by the mass-transter model.

aquifer normally is just below the lowest sequence of the fine-grained beds in the upper part of the Douglas Creek Member or the lower part of the Parachute Creek Member of the Green River Formation. The aquifer generally is about 500 feet thick. but it may be thicker than 1.000 feet in the center of the basin. Water levels in the aquifer vary from a few feet below land surface in the bottom of deeply incised canyons in the southern part of the study area. to more than 100 feet above land surface in the central and northern parts of the study area.

The results of aquifer tests of the Douglas Creek aquifer show a range in transmissivity from 16 to 170 feet squared per day and an estimated range in the storage coefficient from about $7 \times 10^{-4}$ to $2.5 \times 10^{-1}$ (Holmes. 1980 , p. 1). Permeability is primarily intergranular; although locally. fracturing may increase the permeability and enhance transmissivity. The aquifer is under water-table conditions where it crops out in the southern part of the study area and under artesian conditions in the central and northern parts. Maximum yields to individual wells completed in the Douglas Creek aquifer are estimated to be less than $5(0)$ gallons per minute.

Recharge to the Douglas Creek aquifer in the southeastern Uinta Basin originates from precipitation on the outcrop area and from infiltration from streams through alluvial deposits crossing the outcrop area. Leakage from underlying rocks of the Wasatch Formation or from the overlying Parachute Creek Member of the Green River Formation probably is insignificant.

Discharge from the Douglas Creek aquifer is primarily from springs in the outcrop area of the aquifer and discharge

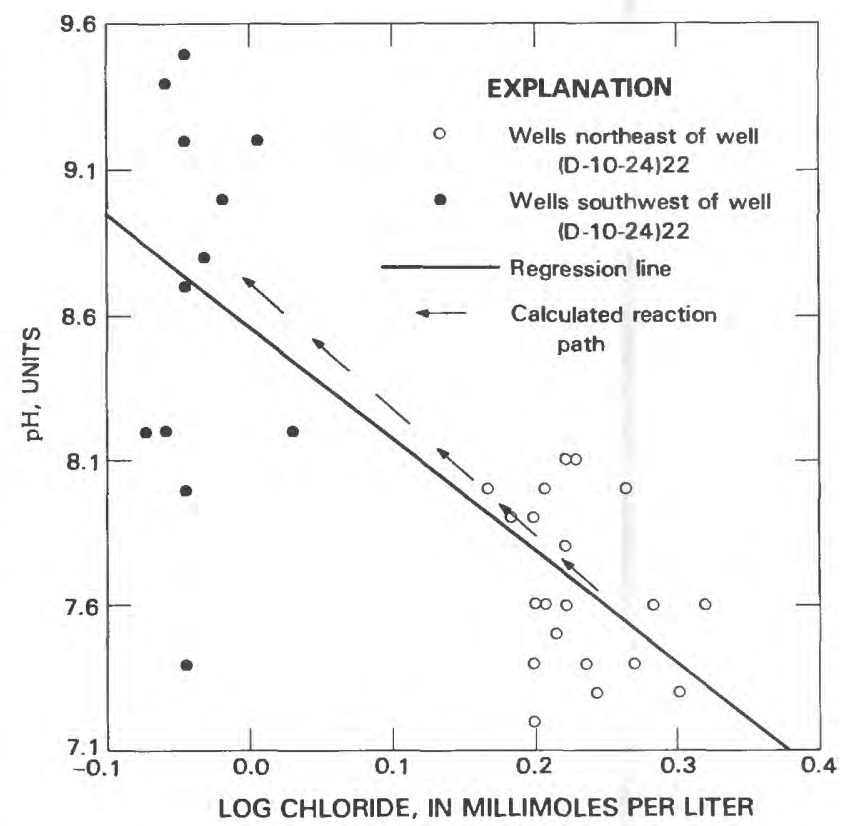

Figure 19. Plot of $\mathrm{pH}$ versus chloride in the bird's-nest aquifer showing the reaction path calculated by the masstransfer model.

to the White and Green Rivers and their major tributaries and associated alluvial aquifers. Some wells discharge small quantities of water from the aquifer in the central part of the study area.

A summary of the ground-water budget for the Douglas Creek aquifer is presented in table 10 .

\section{Recharge}

Recharge to the Douglas Creek aquifer is from precipitation and infiltration from streams.

\section{Precipitation}

Recharge from precipitation on the outcrop of the Douglas Creek aquifer is estimated to average 18,500 acre-feet per year. The recharge occurs at high altitudes in the southern part of the study area where the Douglas Creek aquifer crops out or is near the surface. Precipitation in the outcrop area ranges from 14 to 20 inches per year (Waltemeyer, 1982, pl. 1).

Estimates of recharge from precipitation are based on base flow during December through February as measured at continuous-record gaging stations, partial-record sites, or miscellaneous-measurement sites (fig. 2) located downstream from the outcrop of the aquifer. Measurement of base flow at these sites during December through February represent average discharge from the aquifer during a long time. If it is assumed that all the recharge is discharged by springs in the canyon bottoms and that the aquifer is in steady-state conditions, then the measured discharge in the canyon bottoms must equal the recharge. 
Table 10. Summary of ground-water budget for the Douglas Creek aquifer

\begin{tabular}{lr}
\hline \multicolumn{1}{c}{ Component } & $\begin{array}{r}\text { Long-term average } \\
\text { (acre-feet pervear) }\end{array}$ \\
\hline Recharge: & 18,500 \\
Precipitation & 920 \\
Infiltration from streams & 19,420 \\
$\quad$ Total & \\
Discharge: & \\
Springs in the outcrop area of the aquifer & 18,500 \\
White and Green Rivers and major & \\
$\quad$ tributaries and associated alluvial aquifers & 920 \\
Wells & 250 \\
$\quad$ Total &
\end{tabular}

\section{Infiltration from streams}

Recharge to the Douglas Creek aquifer from stream infiltration was estimated from a digital-computer model to be 920 acre-feet per year. The recharge occurs along major tributaries of the White and Green Rivers in the central and southern parts of the study area where the aquifer is at or near the surface. Streamflow infiltrates the Douglas Creek aquifer after passing through thick alluvial deposits. In the central and northern parts of the study area, the aquifer is overlain by the relatively impermeable marlstone, siltstone, and oil-shale beds of the Parachute Creek Member, which prevent recharge.

\section{Movement}

Water in the Douglas Creek aquifer generally moves from recharge areas at high altitudes in the southeastern part of the study area north or northwest toward discharge areas along the Green and White Rivers and perhaps to other more distant discharge areas. In the southern part of the study area where the aquifer is incised by deep, narrow canyons. some ground water probably moves toward discharge points at numerous springs in the canyon bottoms.

\section{Storage}

The amount of recoverable water stored in the Douglas Creek aquifer is estimated to be 16 million acre-feet. The estimate is based upon an areal extent of 2,500 square miles, an average thickness of $500 \mathrm{feet}$, and an average specific yield of 0.02 .

Water-level measurements from the six test holes indicate that water-level fluctuations are less than 10 feet per year. The fluctuations probably are due to seasonal variations in the balance between recharge and discharge.

\section{Discharge}

Ground water in the Douglas Creek aquifer is discharged by springs in the outcrop area of the aquifer, seepage to the White and Green Rivers and major tributaries, and wells.

\section{Springs in the Outcrop Area of the Aquifer}

Discharge from the Douglas Creek aquifer through springs in the southern part of the study area is estimated to be 18,500 acre-feet per year.

\section{Seepage to the White and Green Rivers and Major Tributaries}

Discharge from the Douglas Creek aquifer to the White and Green Rivers and to major tributaries is estimated from a digital-computer model to he 920 acre-feet per year. The discharge occurs in the central, northern, and western parts of the study area where the potentiometric surface of the aquifer is above the bottoms of the canyons.

\section{Wells}

Discharge from the Douglas Creek aquifer through wells is estimated to be 250 acre-feet per year. Most discharge is from producing or abandoned gas wells in the central part of the study area where artesian pressure causes water to flow at the land surface. Discharge from these wells range from about 1 to 35 gallons per minute. Well (D-14-22) 2aaa-1 ( $\mathrm{pl}$. 1), provides water for domestic use at the Geokinetics Inc. operation (fig. 1).

\section{Digital-Computer Model of the Flow System}

\section{Design}

A simulation of an artesian aquifer with leaky streambeds was used to model part of the flow system in the Douglas Creek aquifer. The aquifer boundaries, grid size, and leakage nodes used in the model are shown in figure 20.

The aquifer is under water-table conditions south of the area modeled, but that part of the aquifer was not included in the model because of insufficient data. The southern extent of the model is at the approximate outcrop of the aquifer in the bottoms of the major drainages. The effects on the simulated results on setting the boundary at these locations should be minimal. 


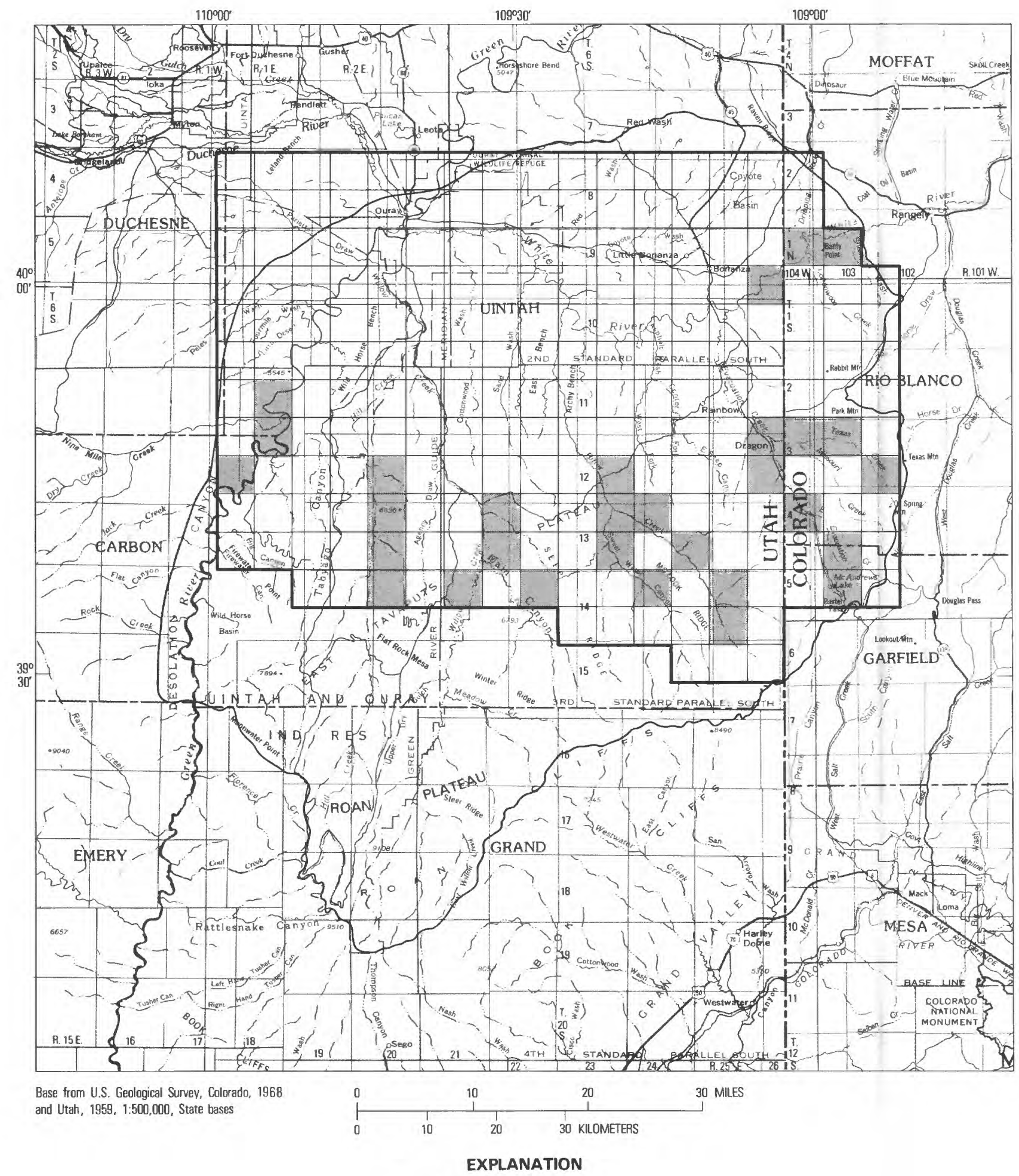

LEAKAGE NODE

BOUNDARY OF MODEL

BOUNDARY OF STUDY AREA

Figure 20. Aquifer boundaries, grid size, and leakage nodes used in the digital-computer model of the Douglas Creek aquifer. 
Input data for the model include transmissivity, storage coefficient, vertical hydraulic conductivity, altitude of leaky streambeds and river heads, confining-bed thickness, initial heads, and boundary conditions. Sources of the input data can be found in Conroy and Fields (1977). Conroy (1979 and 1980). and Holmes (1980).

Values of transmissivity used in the model are based upon aquifer-test results given in Holmes (1980). and values were extrapolated to areas where data were not available. An artesian storage coefficient of $1 \times 10^{-4}$ was used throughout the modeled area. Values of transmissivity used in the model ranged from 25 to 100 feet squared per day and may differ somewhat from point values because they are applied to a much larger area and represent an average value for that area. The values for transmissivity used in the model are shown in figure 21 .

River leakage nodes were used in the canyon bottoms of the Green and White Rivers and in Hill, Willow, Sweet Water, Bitter. and Evacuation Creeks where the aquifer crops out (fig. 20 ). The vertical hydraulic conductivity of the confining layer between the streambeds and the aquifer was estimated by trial and error during calibration of the model. A value of $3.5 \times 10^{-4}$ foot per second was found to give the best results. The thickness of the confining layer between the streambeds and aquifer was obtained from table 2.

No-flow boundaries were used on the eastern, western. and southern part of the study area where the aquifer crops out. For computational purposes, a no-flow boundary also was used on the northern edge of the study area, although some water may be moving out of the modeled area in this direction.

\section{Calibration}

Calibration of the steady-state model was obtained by setting all storage terms to zero and varying transmissivity and vertical hydraulic conductivity until a reasonable match between computed and measured heads was obtained. Little water-level data that could be used in the calibration of the model were available for the period before this study. Although abandoned gas wells had been used for livestock watering for more than 15 years, water-level measurements had not been made at these wells. Water levels are estimated to have declined as much as 100 feet at and near these wells. but the regional potentiometric surface probably has not changed significantly.

The final steady-state solution for the potentiometric surface and areas of recharge and discharge are shown in figures 22 and 23 . The potentiometric surface produced by the model generally is within 20 feet of measured values, and no computed water level differed by more than 25 feet from the measured value for the same node. Only six data points were considered reliable for calibration; thus owing to the large area covered, the model is considered at best an approximation of actual aquifer conditions.

The steady-state model indicates a net recharge rate from stream infiltration of about 920 acre-feet per year, as follows: Evacuation Creek, 210; Sweet Water Canyon Creek. 260): Willow Creek, 20: and Hill Creek, 430.

The results of the model were compared with streamflow records at gaging stations 09306760 and 09306780 on Sweet
Water Canyon (pl. 1). Streamflow losses between the two stations during each January from 1975-79 amounted to about 280 acre-feet per year. This compares closely with about 260 acre-feet per year calculated by the model for this reach of the canyon.

Discharge from the aquifer also was calculated to be about 920 acre-feet per year, as follows: Bitter Creek. 120; White River, 230; and the Green River, 570.

\section{Simulated Effects of Oil-Shale Development}

Effects of oil-shale development on the Douglas Creek aquifer should be minimal. The aquifer is separated from the proposed mining zone at Federal lease tracts Ua and Ub by about 400 feet of fine-grained sediments of the Parachute Creek Member. The construction of a reservoir on the White River will have little, if any, effect on the aquifer. The only major effect would result from withdrawal of ground water from the aquifer to supply water for development.

The model was used to evaluate the potential of the Douglas Creek aquifer to yield large amounts of water for oil-shale development. The production wells were simulated near the Federal lease tracts $\mathrm{Ua}$ and $\mathrm{Ub}$ and near the TOSCO Corp. site at Sand Wash (fig. 24). The simulation indicates that the aquifer is capable of supplying some water for oil-shale development. Total maximum yield from the two simulated wells would be about 700 acre-feet per year during a 20-year life for a mine, and at the end of 20 years, the water levels in the production wells would be near the base of the aquifer. but because of the steep gradients only a small area around the wells would be under water-table conditions. The drawdowns in the Douglas Creek aquifer after 20 years of pumping 500 acre-feet per year at the TOSCO Corp. site and 160 acre-feet per year at tracts $\mathrm{Ua}$ and $\mathrm{Ub}$ are shown in figure 24.

Sensitivity tests were used to evaluate the model response to changes in transmissivity, storage coefficient, vertical hydraulic conductivity, and boundary conditions. The range of values used in the sensitivity tests reflects the confidence in the data. A 10 -fold increase in storage coefficient and vertical hydraulic conductivity of the confining bed had little effect on the simulated results. A 2-fold increase in transmissivity resulted in a total maximum production of about 1.400 acre-feet per year from the two simulated wells. Replacing the no-flow boundaries on the north and west with constant-head houndaries to allow for possible inflow from outside the model boundaries had very little effect on the model results.

It is estimated that a pumping center in the southern part of the study area could supply an additional 700 acre-feet of water per year from the Douglas Creek aquifer. or a total of 1,400 acre-feet per year, but some interference between well fields could be expected.

\section{Quality}

\section{Chemical and Physical Characteristics}

There are distinct variations of the water quality in the Douglas Creek aquifer. For the purpose of discussion, the aquifer can be divided into southern, central, and northern 


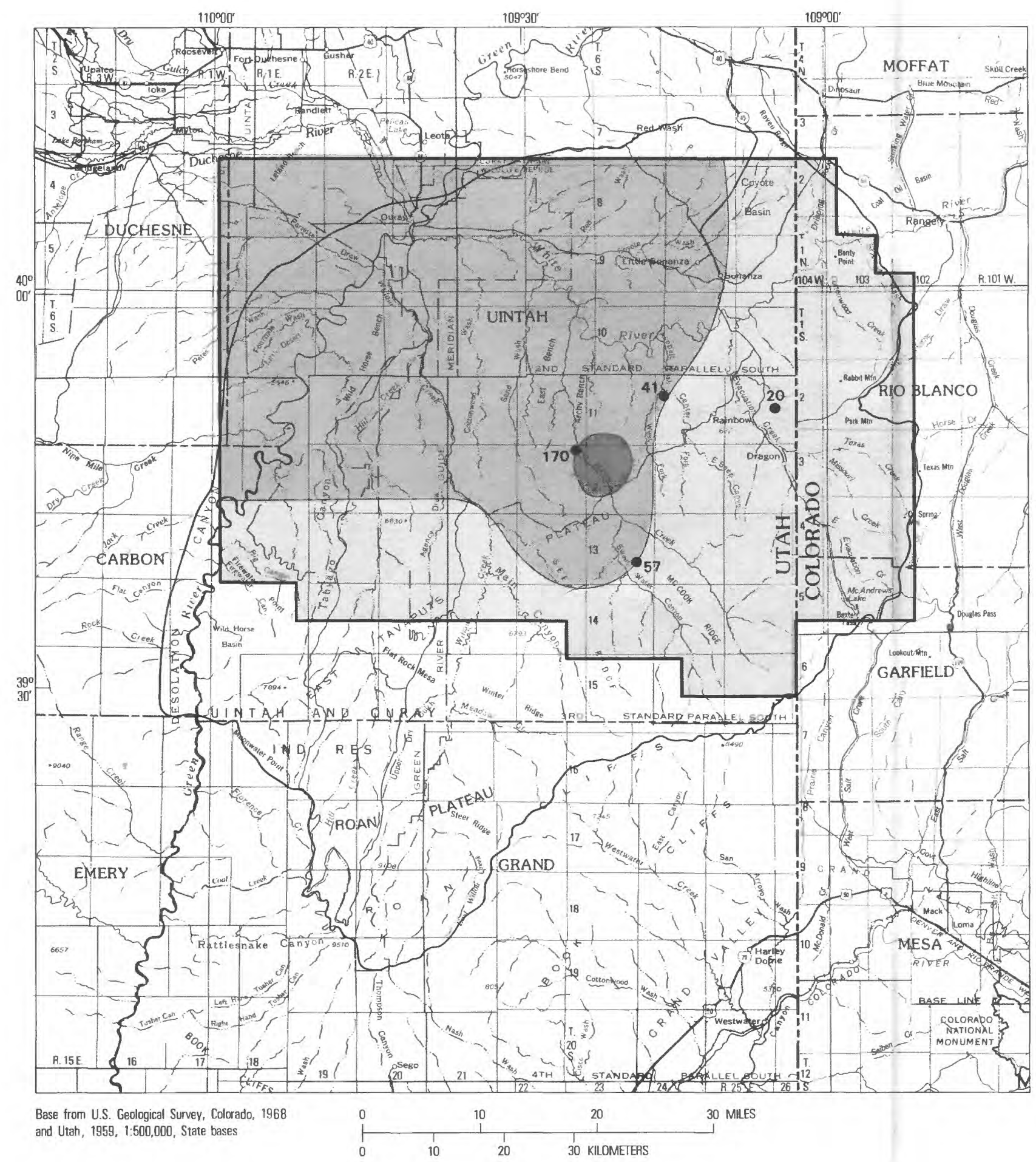

EXPLANATION

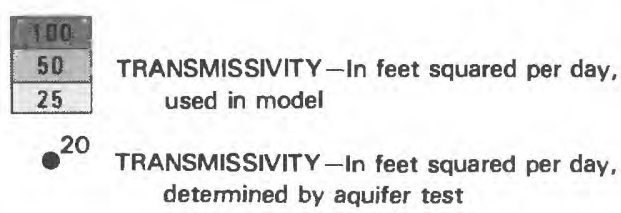

BOUNDARY OF MODEL

BOUNDARY OF STUDY AREA determined by aquifer test

Figure 21. Transmissivity of the Douglas Creek aquifer used in the digital-computer model. 

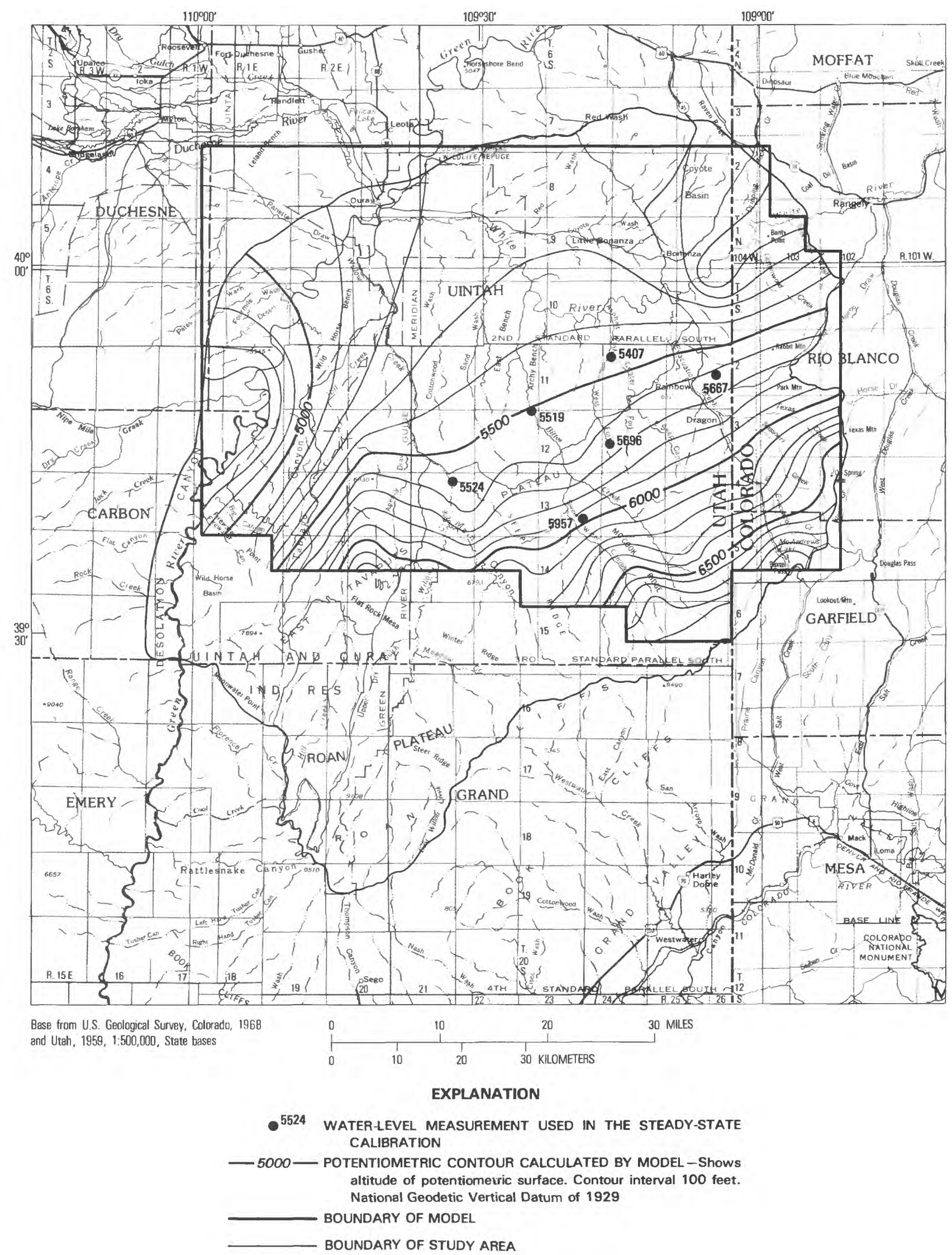

Figure 22. Potentiometric-surface contours of the Douglas Creek aquifer, computed by the digital-computer model. 


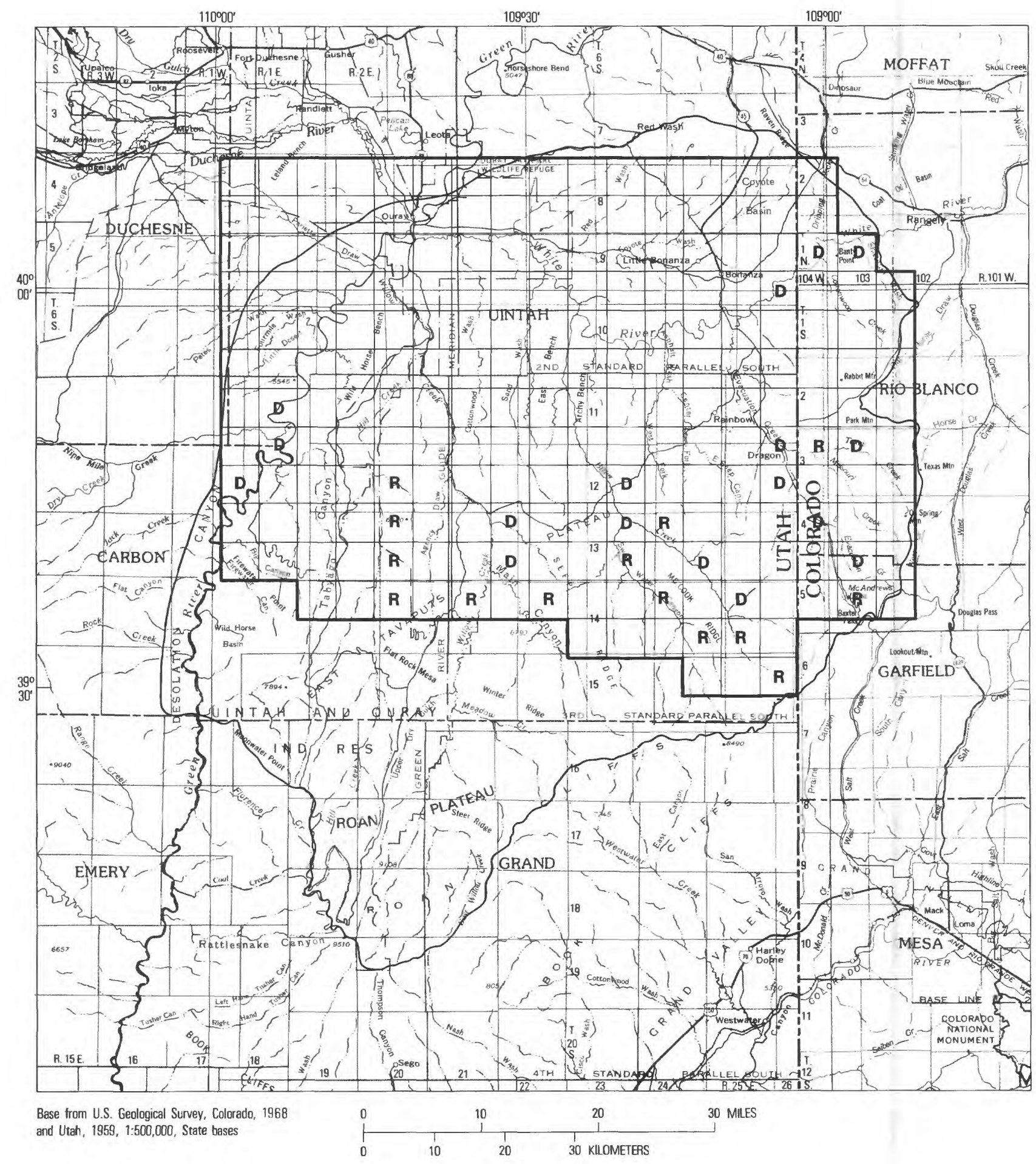

EXPLANATION

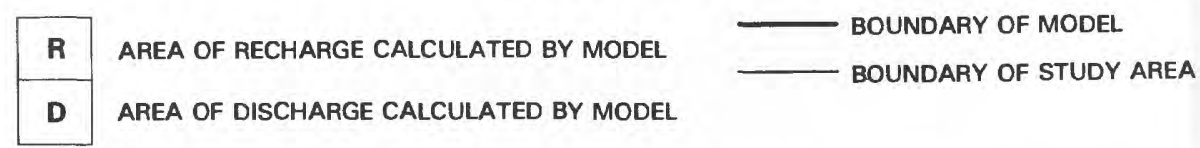

Figure 23. Distribution of recharge and discharge, computed by the digital-computer model for the Douglas Creek aquifer. 

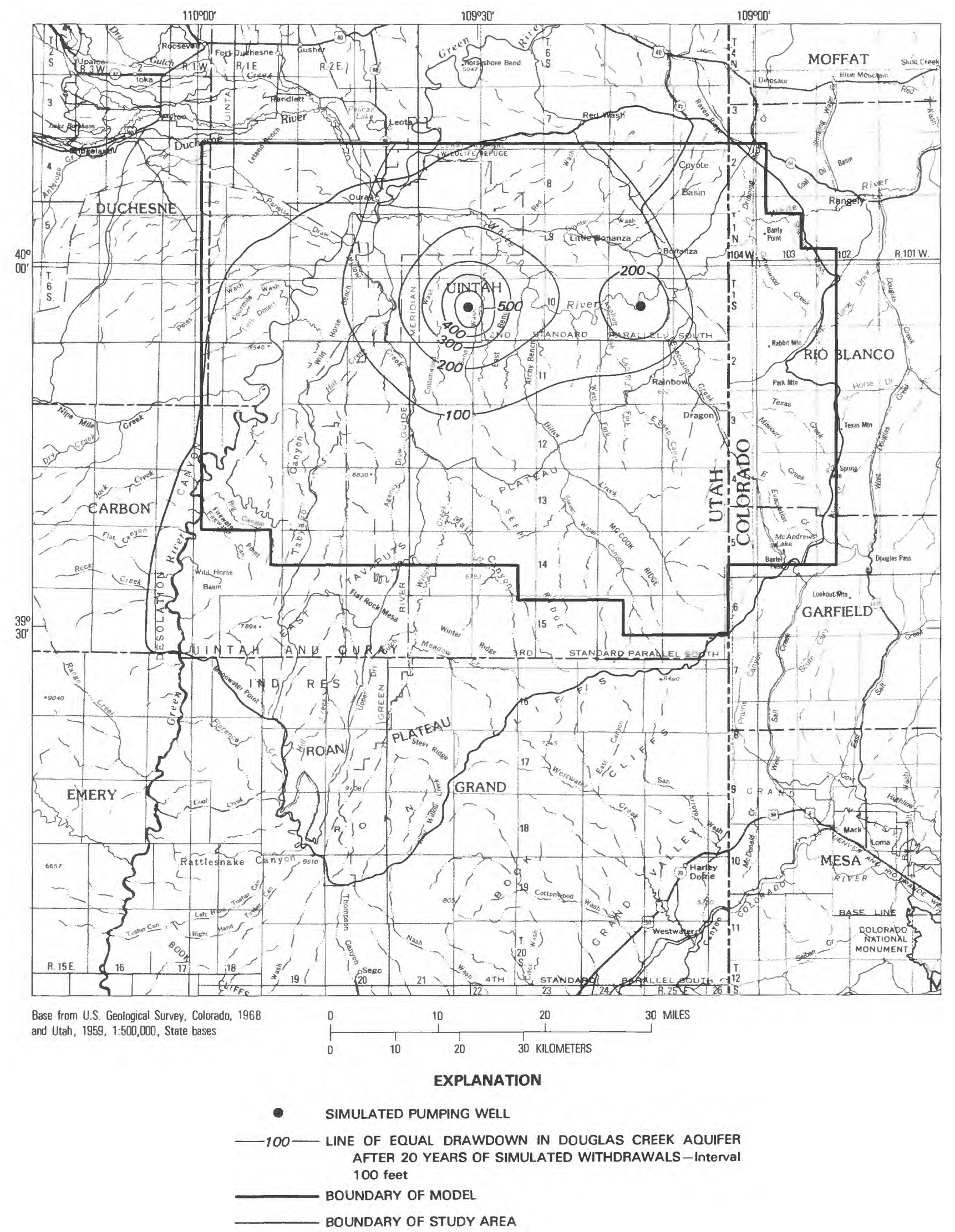

Figure 24. Drawdown in the Douglas Creek aquifer after 20 years of simulated withdrawals, computed by the digitalcomputer model. 


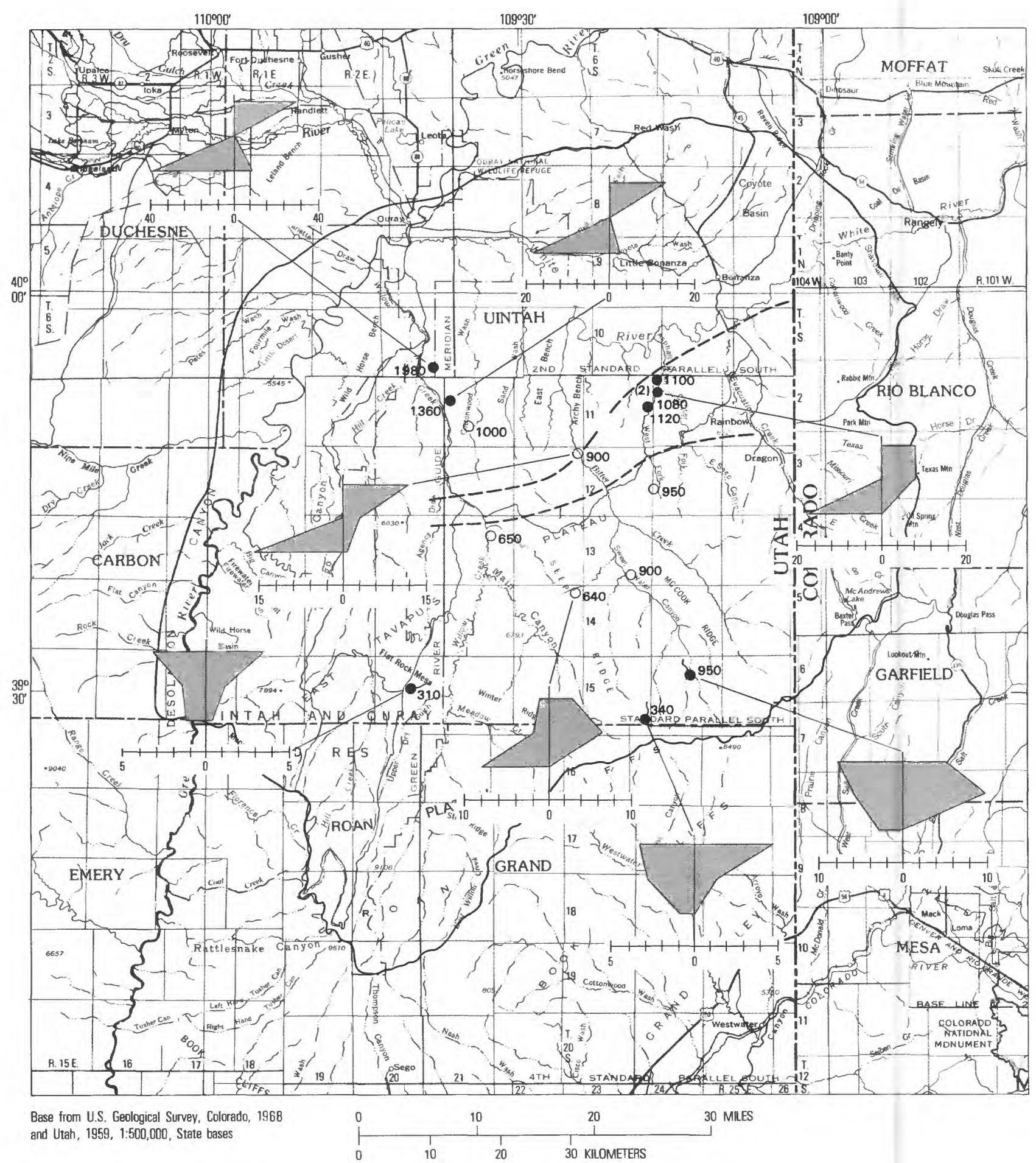

Figure 25. Variation in mean dissolved-solids concentrations and chemical character of water in the Douglas Creek aquifer.

parts. shown in figure 25. These divisions do not exactly parallel the potentiometric surface shown in figure 22. but they do represent changes in the quality of the water in the general direction of flow. The quality for each part is summarized in table 11.

Water in the southern part of the aquifer most closely resembles the water from springs that discharge in canyon bottoms. This water is dominated by sulfate, bicarbonate, sodium. magnesium. or calcium as a result of reactions that take place in the recharge area (Kimball, 1981. p. 10-13). As the water moves downgradient in the aquifer, further reactions cause additional changes in the chemical quality. In the central part of the aquifer, bicarbonate (plus carbonate) becomes more abundant than sulfate, calcium and magnesium concen- 
EXPLANATION
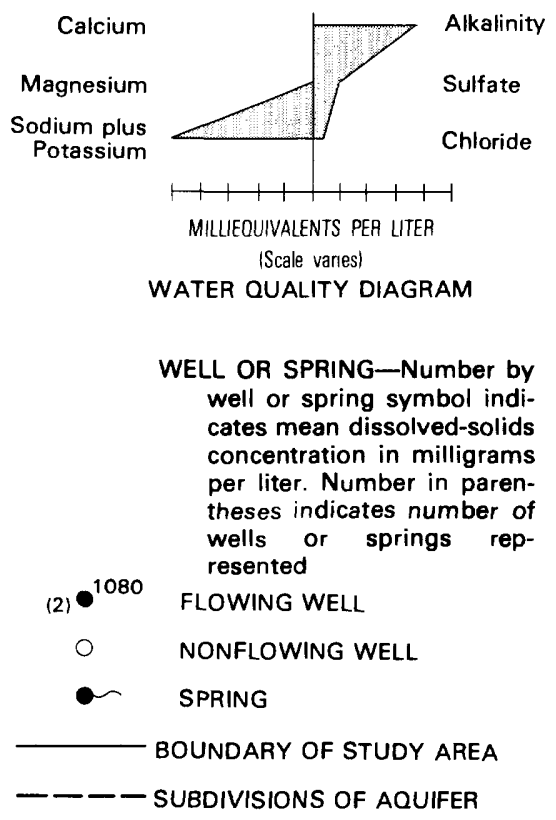

trations decrease and sodium increases. In the northern part of the aquifer, sulfate. calcium, and magnesium concentrations are almost zero and hicarbonate. carbonate. and sodium are the most abundant ions.
The dissolved-solids concentration increases from south to north in the aquifer (fig. 251. This change is in the direction of the flow path. Water temperature also increases along the flow path from a mean in the south of about $19^{\circ} \mathrm{C}$ to a mean in the central and northern of about $24^{\circ} \mathrm{C}$.

The mean value of $\mathrm{pH}$ in the southern part of the aquifer is 8.2, in the central part it is 8.7, and in the northern part it is 8.4. Sulfate reduction and the precipitation of carbonate minerals result in an increase of hydrogen-ion concentrations. Thus, $\mathrm{pH}$ should decrease from south to north in the aquifer. It is possible that the decrease from the central to the northern parts of the aquifer is due to $\mathrm{pH}$ control from these reactions. but it is unclear if these mean $\mathrm{pH}$ values are comparable as a continuous sequence. The mass-transfer model below describes the general changes in $\mathrm{pH}$ as the reactions proceed.

As the concentration of calcium decreases in the aquifer. the concentration of fluoride generally increases. The mean fluoride concentration in the southern part of the aquifer is 0.3 milligram per liter, in the central part it is 2.4 milligrams per liter. and in the northern part it increases to 7.7 milligrams per liter. Although fluoride $\left(\mathrm{CaF}_{2}\right)$ was not detected by X-ray diffraction in the aquifer materials. its solubility could control the concentration of fluoride. Apatite $\mathrm{Ca}_{2}\left(\mathrm{PO}_{4}\right)_{3}(\mathrm{~F})$ also could control the concentrations. With lesser concentrations of calcium. the solubility relations allow the concentration of fluoride to increase. These greater concentrations of fluoride in the northern part exceed water-quality criteria established by the U.S. Environmental Protection Agency (1976, p. 5).

The mean concentration of silica in the aquifer generally

Table 11. Summary of chemical quality of water in the Douglas Creek aquifer

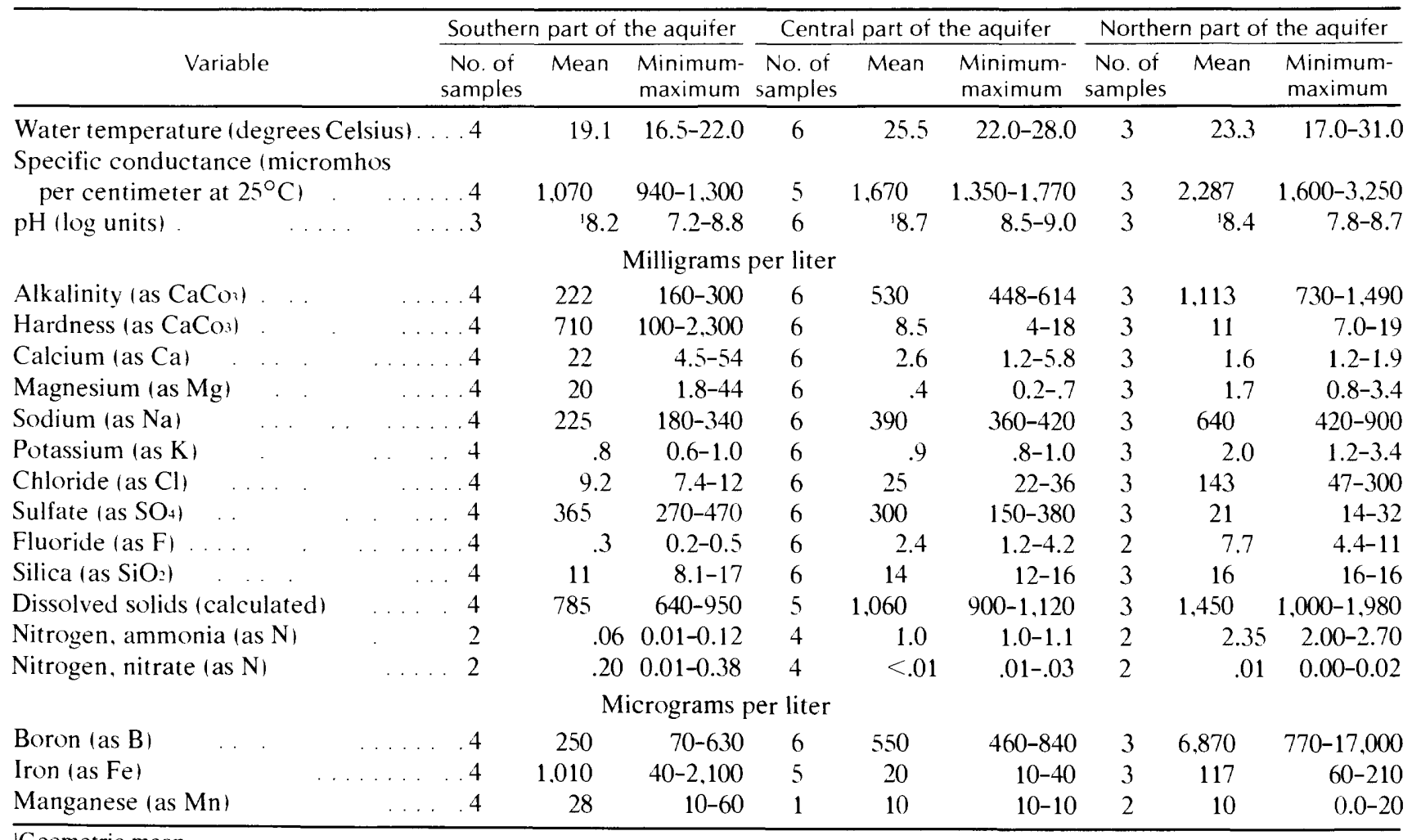

Geometric mean. 
remains constant at about 15 milligrams per liter. Although this exceeds the concentration that would be present if silica were controlled by the solubility of quartz. it is considerably less than the solubility limits of other silica phases. As in the other aquifers, the silica concentration is very likely controlled by sorption reactions with the clay minerals that are abundant in the aquifer materials.

The change in the predominant nitrogen species in the Douglas Creek aquifer is similar to that in the bird's-nest aquifer. As the water becomes more reducing. the dominant nitrogen species change from nitrate to ammonia. In the southern part of the aquifer, the mean concentration of ammonia is 0.06 milligram per liter as $\mathrm{N}$, in the central part it increases to 1.00 milligram per liter. and in the northern part it increases to 2.35 milligrams per liter. Nitrogen, as nitrate, on the other hand, has a mean of about 0.20 milligram per liter as $\mathrm{N}$ in the southern part and decreases to 0.01 milligram per liter or less in the central and northern parts.

A few trace elements were determined in samples from the Douglas Creek aquifer. The concent rations of boron. iron, and manganese show two different patterns in the aquifer. Boron concentrations in the southern part of the aquifer have a mean of 250 micrograms per liter, which increases to 550 micrograms per liter in the central part and 6.890 micrograms per liter in the northern part. In the northern part of the aquifer. boron makes a small contribution to the titration alkalinity. The increase of boron most likely results from increased contact of the aquifer water with the rocks of the Green River Formation.

In contrast to boron, the mean concentrations of iron and manganese decrease in the water from south to north. Both iron and manganese form sulfide minerals, and the sulfides ( particularly pyrite. $\mathrm{FeS}_{2}$ ) are present in the aquifer materials. As sulfate reduction takes place in the aquifer, the abundance of sulfide species increases, and these species are available to precipitate as metal sulfide minerals. Thus, one would expect the concentrations of iron and manganese to decrease in solution.

During test-drilling operations, water was encountered in the Douglas Creek Member of the Green River Formation which was of different chemical quality than the water in Douglas Creek aquifer. At wells (D-11-24) 7acd-1 and (D-12-22) $1 \mathrm{bbb}-1$, the water in a zone near the top of the Douglas Creek Member had a large dissolved-solids concentration. Measurement of specific conductance during drilling in the two wells indicated maximum values of 45.000 and 33.000 micromhos per centimeter at $25^{\circ} \mathrm{C}$ (Holmes, 1980 . tables 4 and 12 .

A sample collected during drilling at well (D-13-23) 26hdc-1 had a dissolved-solids concentration ( sum of constituents) of 4.935 milligrams per liter. Most of the dissolved solids were sodium and hicarbonate. The water was similar to the reduced water in the northern part of the Douglas Creek aquifer in terms of general chemical character, hut it contained extremely large concentrations of fluoride and boron. The concentration of fluoride was 110 milligrams per liter. Such a large value only could be possible when calcium is virtually absent from the solution due to the precipitation of calcite. Such a condition in Lake Magadi, Kenya, results in similarly large concentrations of fluoride in a sodium carbonate brine (Jones and others. 1977 ).

The boron concentration was 70 milligrams per liter. The water is not in a part of the Green River Formation that contains evaporite minerals; thus such a large boron concentration may be a result of some residual "connate" water present in the formation. The sodium bicarbonate brines of ancient Lake Uinta (Bradley and Eugster. 1969. p. B6.3) probably also had large boron concentrations. This water in some respects is similar to the "black water" described by Dana and Smith 11973). The water commonly has a distinct green color when it discharges from a well.

Although the water from the Douglas Creek aquifer is not suitable for irrigation or public supply, industrial uses such as washing and cooling would not be prohibited by its chemical quality. The values of alkalinity are large. but in the north and central parts, the hardness is small. The dissolved-solids concentration is less than that of the water in the bird's-nest aquifer. Admixture with any of the very saline water from near the top of the Douglas Creek Member, however. would decrease the usefulness of the water from the Douglas Creek aquifer.

\section{Mass-Transfer Model}

The mass-transfer model of the Douglas Creek aquifer. which is summarized in table 12. was divided into two segments. The first segment followed the changes in chemical character of the water from the southern to the central part of the aquifer. The second segment modeled the subsequent changes from the central to the northern part of the aquifer. The wetls in each part of the aquifer and the changing chemical character of the water are shown in figure 25. The change in $\mathrm{pH}$ through the aquifer and the changes in major constituents were attributed to sodium magnesium ion exchange, equilibrium with calcite, dolomite. and carbon dioxide, and reduction of sulfate by organic carbon. These reactions were modeled and the predicted reaction path is shown in the plot of alkalinity versus sulfate in figure 26. Once again. there appears to be a carbonate-clay buffer for the $\mathrm{pH}$. The increase in alkalinity is due to the reduction of sulfate. A few analyses of gas from wells down the hydraulic gradient in the Douglas Creek aquifer consistently showed the presence of methane. carbon dioxide. and hydrogen sulfide. which are all products of the proposed reactions. Methane is produced by the further breakdown of organic carbon (Thorstenson and others. 1979. p. 1493. reaction 12 .

\section{SUMMARY}

Ground water in the southe astern Uinta Basin is found in three principal aquifers. Alluvial aquifers are in unconsolidated valley-fill deposits along major drainages. The bird's-nest aquifer is in the Parachute Creek Member of the Green River Formation in the central part of the study area. The Douglas Creek aquifer includes parts of the Douglas Creek Member of the Green River Formation and some intertonguing beds of the Renegade Tongue of the Wasatch Formation.

Alluvial aquifers are small in areal extent and have relatively small hydraulic conductivities. An estimated 675,000 acre-feet of water is stored in alluvial ayuifers, but maximum yields to individual wells are less than 1.000 gallons per minute. 
Table 12. Summary of mass-transfer model of the Douglas Creek aquifer |Mean concentrations, in millimoles per liter unless noted: $\mathrm{meq} / \mathrm{L}=$ milliequivalents per liter: $\log$ atm. $=\log$ atmospheric

\begin{tabular}{|c|c|c|c|c|c|}
\hline \multirow[b]{2}{*}{ Constituent } & \multirow{2}{*}{$\begin{array}{l}\text { South part of the aquiter } \\
\text { Initial solution } \\
\text { (4 samples) }\end{array}$} & \multicolumn{2}{|c|}{ Central part of the aquifer } & \multicolumn{2}{|c|}{ North part of the aquiter } \\
\hline & & $\begin{array}{c}\text { Analvzed } \\
\text { (5 samples) }\end{array}$ & Calculated & $\begin{array}{c}\text { Analyzed } \\
(3 \text { samples })\end{array}$ & Calculated \\
\hline Calcium & 0.324 & 0.062 & 0.072 & 0.047 & 0.048 \\
\hline Magnesium & .823 & .025 & .027 & .033 & .034 \\
\hline Sodium & 7.830 & 17.834 & 17.172 & 26.099 & 26.438 \\
\hline Chloride & .231 & .790 & .790 & 1.326 & 1.326 \\
\hline Alkalinity (meq/L) & 2.786 & 9.997 & 10.058 & 22.125 & 22.967 \\
\hline Sulfate. & 3.331 & 3.5 .39 & 2.912 & .146 & .001 \\
\hline $\mathrm{pH}$ (units) & 18.80 & 18.70 & 18.72 & 18.70 & 18.69 \\
\hline Calcite saturation ${ }^{2}$ & 0.501 & 0.267 & 0.267 & .339 & .339 \\
\hline Dolomite saturation ${ }^{2}$ & 1.496 & .196 & .196 & .627 & .627 \\
\hline $\begin{array}{l}\text { Carbon dioxide } \\
\text { (log atm.) }\end{array}$ & -3.6182 & -2.987 & -2.987 & -2.654 & -2.654 \\
\hline $\mathrm{K}$ exchange $(\log )$ & - & 1.269 & $\begin{array}{c}1.269 \\
\text { Mass } \\
\text { transfer }\end{array}$ & - & $\begin{array}{c}1.546 \\
\text { Mass } \\
\text { transfer }^{3}\end{array}$ \\
\hline Calcite & . & . & -3.840 & & -4.062 \\
\hline Dolomite & & & +3.589 & & +4.403 \\
\hline Carbon dioxide. & & & +7.935 & & +5.546 \\
\hline $\begin{array}{l}\text { Sodium-magnesium } \\
\text { ion exchange }\end{array}$ & & & +4.385 & & +4.034 \\
\hline Hematite & . & . & +.248 & & +.885 \\
\hline
\end{tabular}

'Geometric mean.

'Represented as logarithm of the ion activity product divided by the equilibrium constant for each particular mineral. The ion activity products were calculated by PHREEQE (Parkhurst. Thorstenson. and Plummer. 1980).

'Mass transfer is the millimoles of each mineral dissolved (positive valuel or precipitated Inegative valuel.

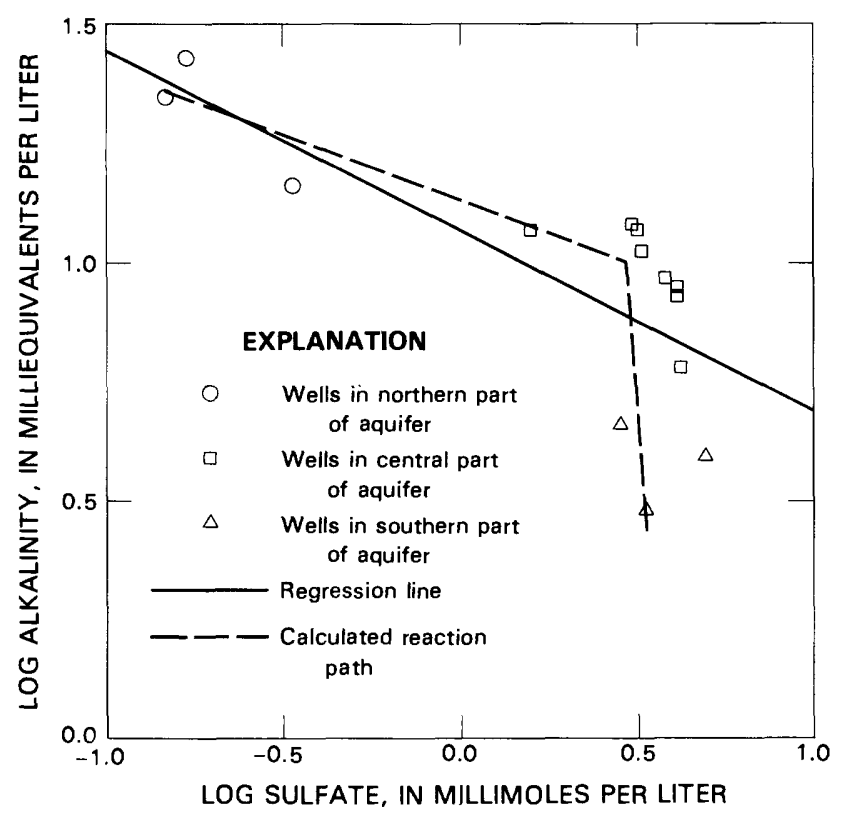

Figure 26. - Plot of alkalinitv versus sulfate in the Douglas Creek aquifer showing the reaction path calculated by the mass-transter model.
Recharge is primarily from stream infiltration and discharge is mainly through evapotranspiration.

The bird's-nest aquifer contains solution cavities caused by the removal of readily soluble nahcolite. Where these cavities are connected by fractures or joints, the permeability is increased significantly. An estimated 1.9 million acre-feet of recoverable water is stored in the bird 's-nest aquifer, and yields to individual wells in some areas may be as much as 5,000 gallons per minute. Recharge is mainly from stream infiltration along Evacuation Creek and downward leakage from the overlying Uinta Formation, and discharge is to the White River and upward leakage to Bitter Creek.

A digital-computer model of the flow system in the bird'snest aquifer indicates that the aquifer could supply about 20.000 acre-feet of water per year for the oil-shale industry. Drawdowns from pumping about 10.000 acre-feet per year near the Federal lease tracts $\mathrm{Ua}$ and $\mathrm{Ub}$ about 20 years would range from more than 250 feet near the simulated pumping wells to between about 20 and 200 feet at the boundaries of the model. Dewatering during construction of a vertical access shaft on Federal lease tracts $\mathrm{Ua}$ and $\mathrm{Ub}$ would require a pumping rate of about 900 gallons per minute.

The construction of a reservoir on the White River would cause water levels to rise between 0 and 45 feet in the bird'snest aquifer. Downward leakage from the overlying Uinta Formation may probably increase substantially due to the construction of the reservoir. 
The Douglas Creek aquifer consists of beds of sandstone and limestone of the Douglas Creek Member of the Green River Formation and sandstone beds of the Wasatch Formation. The transmissivity of the aquifer is relatively small, and maximum yields to individual wells probably are less than 500 gallons per minute. Recharge is primarily from precipitation and discharge is mostly through springs in the outcrop area of the aquifer. An estimated 16 million acre-feet of water is recoverable.

A digital-computer model of the Douglas Creek aquifer indicates that the aquifer could supply a maximum of about 1.400 acre-feet per year for oil-shale development. After 20 years of pumping, water levels in the production wells could be near the base of the aquifer.

The chemical quality of the ground water shows considerable variation. Water from alluvial ayuifers is characterized by large concentrations of major dissolved solids and boron. Of the two aquifers in consolidated rocks, the Douglas Creek aquifer has the least mineralized water. None of the water is suitable for irrigation or public supply. but all the water could be used for such industrial uses as washing and cooling.

The variations in water quality can be explained by mass-transfer models that include specific reactions for sodjum magnesium exchange on clay minerals, reduction of sulfate by organic carbon. mixing of different water sources. and equilibrium with calcite, dolomite, sodium sulfate minerals, and carbon dioxide. Chemical changes in the alluvial aquifer in Bitter Creek result from evapotranspiration and subsequent mineral precipitation. In the bird's-nest aquifer. a mixing model is combined with cation exchange. sulfate reduction. and mineral precipitation to explain the changing water quality. Cation exchange, sulfate reduction. and mineral precipitation also can account for the change in water quality in the Douglas Creek aquifer.

\section{REFERENCES CITED}

Boles, J. R.. and Franks, S. G., 1979. Clay diagenesis in Wilcox sandstones of southwest Texas: Implications of smectite diagenesis on sandstone cementation: Journal of Sedimentary Petrology. v. 49. no. 1. p. 55-70.

Bradley. W. H., 1929, The varves and climate of the Green River epoch: U.S. Geological Survey Professional Paper 1.58-E. p. 85-110.

19.31. Origin and Microfossils of the oil shale of the Green River Formation of Colorado and Utah: U.S. Geological Survey Professional Paper 168, 58 p.

1948. Limnology and the Eocene lakes of the Rocky Mountain region: Geological Society of America Bulletin. v. 59 . p. 635-648.

1964. Geology and Green River Formation and associated Eocene rocks in southwestern Wyoming and adjacent parts of Colorado and Utah: U.S. Geological Survey Professional Paper 496-A. 86 p.

Bradley, W. H., and Eugster, H. P. 1969. Geochemistry and paleolimnology of the Trona deposits and associated authigenic minerals of the Green River Formation of
Wyoming: U.S. Geological Survey Professional Paper 496-B, $71 \mathrm{p}$.

Butler, J. R, and England, J. L.. 1979, Vegetation map of the southeastern Uinta Basin. Utah and Colorado: U.S. Geological Survey Miscellaneous Investigations Series Map I-1141.

Cashion, W. B., 1967. Geology and fuel resources of the Green River Formation southeastern Uinta Basin, Utah and Colorado: U.S. Geological Survey Professional Paper 548. $48 \mathrm{p}$.

Coffin, D. L., Welder, F. A., Glanzman. R. K.. and Dutton. X. W.. 1968. Geohydrologic data from the Piceance Creek Basin between the White and Colorado Rivers. northwestern Colorado: Colorado Water Conservation Board Water Resources Circular 12. 38 p.

Conroy. L. S.. 1979. Hydrologic and climatologic data, southeastern Uinta Basin. Utah and Colorado, water year 1977: U.S. Geological Survey Open-File Report $79-1493$ (duplicated as Utah Hydrologic-Data Report 331, 191 p.

1980 . Hydrologic and climatologic data, southeastern Uinta Basin. Utah and Colorado, water year 1978: U.S. Geological Survey Open-File Report 80-1025 iduplicated as Utah Hydrologic-Data Report 34, $166 \mathrm{p}$.

Conroy. L. S., and Fields. F. K., 1977. Climatologic and hydrologic data, southeastern Uinta Basin. Utah and Colorado, water years 1975 and 1976: U.S. Geological Survey OpenFile Report iduplicated as Utah Basic-Data Release 29), $244 \mathrm{p}$.

Dana. G. F., and Smith. J. W. . 1973. Black Trona Water. Green River Basin: Wyoming Geological Association, 25th field conference, p. 153-156.

Deshorough. G. A., and Pitman, J. K.. 1974. Significance of applied mineralogy to oil shale in the upper part of the Parachute Creek Member of the Green River Formation, Piceance Creek Basin. Colorado, in Energy Resources of the Piceance Creek Basin. Colorado. D. K. Murray. ed.. 25th field conference, Rocky Mountain Association of Geologists, $303 \mathrm{p}$.

Drever. J. I., 1982. The geochemistry of natural waters: Englewood Cliffs. New Jersey. Prentice-Hall, $388 \mathrm{p}$.

Drever, J. I. and Smith. C. L., 1978. Cyclic wetting and drying of the soil zone as an influence on the chemistry of ground water in arid terrains: American Journal of Science. v. 278. p. $1448-1454$.

Eugster. H. P.. 1970). Chemistry and origin of the brines of Lake Magadi, Kenya: Mineralogical Society of America Special Paper No. 3. p. 213-235.

Eugster. H. P., and Hardie, L. A., 1978. Saline lakes in Lakes: Chemistry. Geology, Physics. Lerman, A.. ed., New York. Springer-Verlag. p. 237-29,3.

Eugster. H. P.., and Jones. B. F., 1979. Behavior of major solutes during closed-hasin brine evolution: American Journal of Science, v. 270, p. 6(09-6.31.

Hardie. L. A.. 1968. The origin of the recent nonmarine evaporite deposit of Saline Valley. Inyo County, California: Geochimica et Cosmochimica Acta, v. 32. p. 1279-1301.

Hem. J. D.. 197(). Study and interpretation of the chemical characteristics of natural water. second edition: U.S. Geological Survey Water-Supply Paper 1473. 36.3 p.

Holmes. W. F. 1980). Results of test drilling for ground water 
in the southeastern Uinta Basin. Utah and Colorado: U.S. Geological Survey Water-Resources Investigations 8()$-951.90 \mathrm{p}$

Hood. J. W., Mundorff. J. C.. and Price. Don, 1976. Selected hydrologic data Uinta Basin area. Utah and Colorado: U.S. Geological Survey Basic-Data Release 26, $321 \mathrm{p}$.

Johnson, A. I., 1967. Specific yield-compilation of specific yields for various materials: U.S. Geological Survey WaterSupply Paper 1662-D. 74 p.

Jones. B. F.. 1966. Geochemical evolution of closed-basin water in the western Great Basin: Northern Ohio Geological Society Proceedings, 2nd Symposium on Salt, v. 2. p. $181-20)$.

Jones. B. F. Eugster. H. P.. and Rettig, S. L., 1977. Hydrochemistry of the Lake Magadi basin. Kenya: Geochimica et Cosmochimica Acta, v. 41, p. 5.3-72.

Kimball. B. A.. 1981. Geochemistry of spring water, southeastern Uinta Basin. Utah and Colorado: U.S. Geological Survey Water-Supply Paper 2074. 30 p.

Lindskor. K. L., and Kimball. B. A.. 1982, Quantity and quality of streamflow in the southeastern Uinta Basin. Utah and Colorado: U.S. Geological Survey Open-File Report S2-688. $161 \mathrm{p}$.

Mower. R. W.. 1978. Hydrology of the Beaver Valley area. Beaver County. Utah, with emphasis on ground water: Utah Department of Natural Resources Technical Publication $6.3 .90 \mathrm{p}$.

Mower, R. W.. and Cordova. R. M. 1974. Water resources of the Milford area. Utah. with emphasis on ground water: Itah Department of Natural Resources Technical Publication $+3,106 \mathrm{p}$.

Mower, R. W.. and Nace. R. L.. 1957. Water consumption hy water-loving plants in the Malad Valley, Oneida County. Idaho: U.S. Geological Survey Water-Supply Paper 1412. $33 \mathrm{p}$.

Osmond. J. C. 1965. Geotogic history of site of Unita Basin. Utah: American Association of Petroleum Geologists Bulletin, v. 49. p. 1457-197.3.

Parkhurst. D. L.. Thorstenson. D. C.. and Plummer, L. N.. 198(), PHREEQE-A computer progran for geochemical calculations: U.S. Geological Survev Water-Resources Investigations $x()-46,210 \mathrm{p}$.

Picard. M. D., and High, L. R.. Jr., 1472, Paleoenvironmental reconstructions in an area of rapid facies change. Parachute Creek Member of the Green River Formations (Eocene).
Uinta Basin. Utah: Geological Society of America Bulletins. v. 83. p. $2684-27(08$.

Price. Don, and Miller, L. L.. 1975. Hydrologic reconnaissance of the southern Uinta Basin. Utah and Colorado: Utah Department of Natural Resources Technical Publication 49. $87 \mathrm{p}$.

Siever. R., and Woodford. N., 1973, Sorption of silica by clay minerals: Geochimica et Cosmochimica Acta, v. 37, no. 8. p. $1851-1880$.

Smith. C.L., and Drever, J.I., 1976, Controls on the chemistry of springs at Teels Marsh. Mineral County. Nevada: Geochimica et Cosmochimica Acta, v. 40, p. 1080-1093.

Stumm. W., and Morgan. J. J., 1981, Aquatic chemistry. 2nd ed.: New York. John Wiley \& Sons, 780 p.

Thomas, H. E.. 1952. Hydrologic reconnaissance of the Green River in Utah and Colorado: U.S. Geological Survey Circular 129, $32 \mathrm{p}$.

Thorstenson, D. C., Fisher. D. W., and Croft. M. G., 1979. The geochenistry of the Fox Hills-Basal Hell Creek aquifer in southwestern North Dakota and northwestern South Dakota: Water Resources Research. v. 15. p. 1479-1498.

Trescott, P. C.. Pinder, G. F.. and Larson. S. P., 1976. Finitedifference model for aquifer simulations in two dimensions with results of numerical experiments: U.S. Geological Survey Techniques of Water-Resources Investigation of the U.S. Geological Survey. Book 7, Chapter C1, 116 p.

U.S. Environmental Protection Agency. 1976. National interim primary drinking water regulation: Washington, U.S. Government Printing Office. $159 \mathrm{p}$.

1977. Quality criteria for water. 1976: Washington. U.S. Government Printing Office. $256 \mathrm{p}$.

U.S. Geological Survey. 1980. Water resources data for Utah: U.S. Geological Survey Water-Data Report UT-79-1. 6() $4 \mathrm{p}$.

VTN. Colorado, Inc., 1977. Final environmental baseline report: Federal Prototype Oil Shale Leasing Program Tracts Ua and Ub, Utah: White River Shale Project. Vernal, Utah.

Waltemeyer, S. D.. 1982. Selected climatic characteristics of the southeastern Uinta Basin. Utah and Colorado: U.S. Geological Survey Water-Resources Investigations OpenFile Report 82-41, 3.3 p.

White River Shale Project, undated, Detailed development plan: Federal lease tracts Ua and Ub: Vernal, Utah, White River Shale Project, 2 vols. 


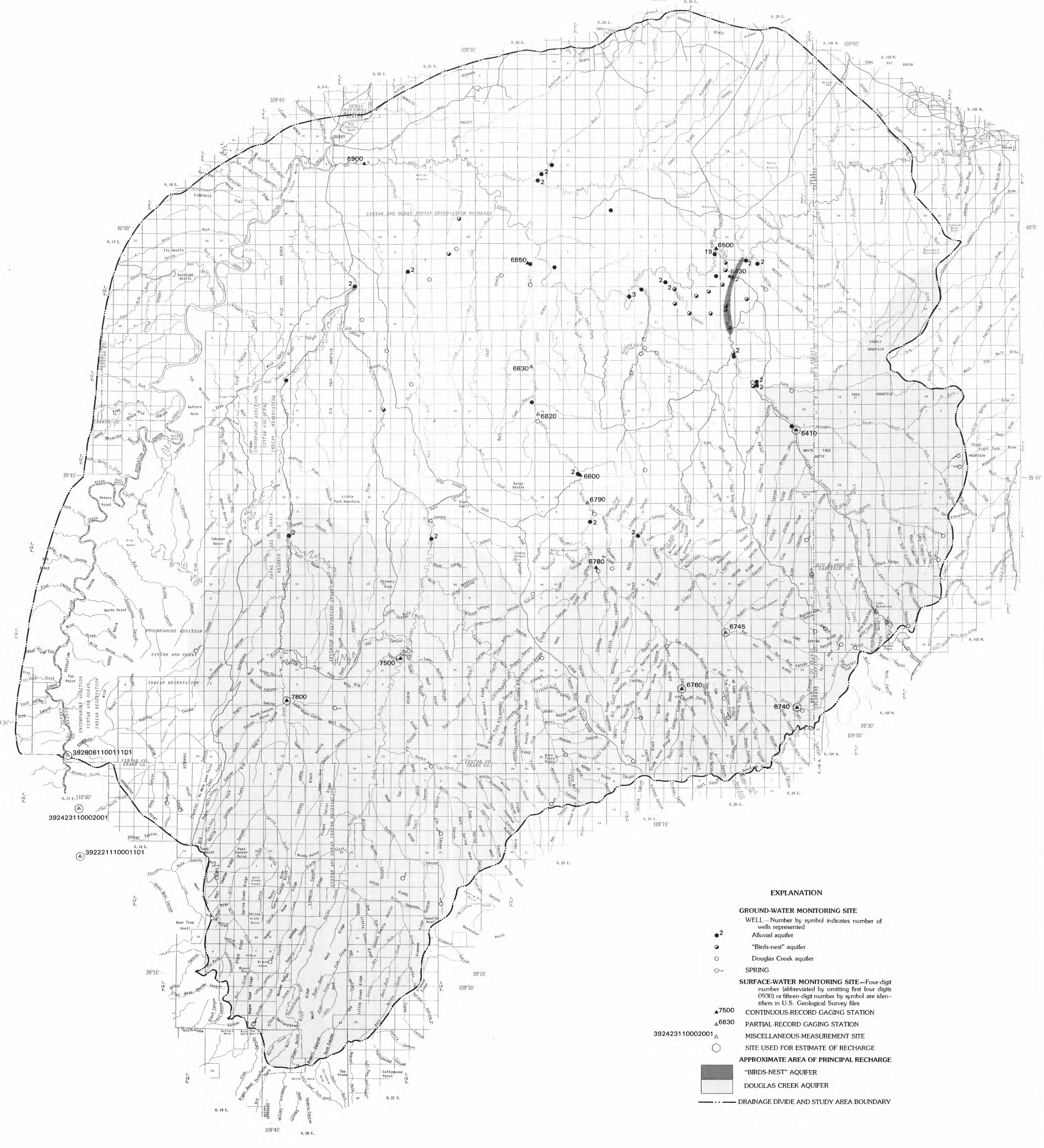

